Utah State University

DigitalCommons@USU

$12-2019$

\title{
Dry Heat Among the Red Rocks: Risk Perceptions and Behavioral Responses to Extreme Heat Among Outdoor Recreationists in Southeastern Utah
}

Kirsten M. Goldstein

Utah State University

Follow this and additional works at: https://digitalcommons.usu.edu/etd

Part of the Geography Commons

\section{Recommended Citation}

Goldstein, Kirsten M., "Dry Heat Among the Red Rocks: Risk Perceptions and Behavioral Responses to Extreme Heat Among Outdoor Recreationists in Southeastern Utah" (2019). All Graduate Theses and Dissertations. 7683.

https://digitalcommons.usu.edu/etd/7683

This Thesis is brought to you for free and open access by the Graduate Studies at DigitalCommons@USU. It has been accepted for inclusion in All Graduate Theses and Dissertations by an authorized administrator of DigitalCommons@USU. For more information, please contact digitalcommons@usu.edu.

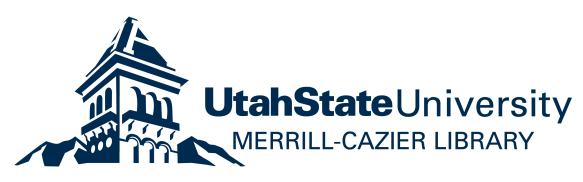


DRY HEAT AMONG THE RED ROCKS: RISK PERCEPTIONS AND BEHAVIORAL RESPONSES TO EXTREME HEAT AMONG OUTDOOR RECREATIONISTS

IN SOUTHEASTERN UTAH

by

Kirsten M. Goldstein

A thesis submitted in partial fulfillment

of the requirements for the degree

of

MASTER OF SCIENCE

in

Geography

Approved:

Peter D. Howe, Ph.D.

Major Professor

Jordan Smith, Ph.D.

Committee Member
Courtney Flint, Ph.D.

Committee Member

Richard S. Inouye, Ph.D.

Vice Provost of Graduate Studies

UTAH STATE UNIVERSITY

Logan, Utah 
Copyright (C) Kirsten M. Goldstein 2019

All Rights Reserved 


\begin{abstract}
Dry heat among the red rocks: risk perceptions and behavioral responses to extreme heat among outdoor recreationists in southeastern Utah

by

Kirsten M. Goldstein, Master of Science
\end{abstract}

Utah State University, 2019

Major Professor: Dr. Peter D. Howe

Department: Environment and Society

Hot dry weather poses health risks that may be underestimated by people unfamiliar with their occurrence. Risk perceptions of extreme heat are an important research area because heat is a major global hazard that can cause severe and fatal physical responses in the human body. However, if people have an appropriate awareness of the hazard and necessary resources, they may be more likely to act in ways that reduce their risks. An increasing number of tourists are visiting national parks in the Southwestern United States, exposing more people to heat-related health risks. However, risk perceptions of extreme heat are not well understood. Even less understood is how risk perceptions vary among populations that do not regularly experience the climate in a specific place, such as tourists. This investigation focuses on how geographic differences and thermal perceptions are associated with risk perceptions of extreme heat. It is designed to learn more about how people respond to 
an extremely hot and dry environment and how to communicate about weather conditions more effectively in the future. Findings show that visitors are likely to overestimate the temperature when the temperature is low (below $35^{\circ} \mathrm{C}$ ), and underestimate the temperature when the temperature is high $\left(\right.$ above $\left.35^{\circ} \mathrm{C}\right)$. Participants with a higher risk perception were more likely to have checked the weather for the day. Lastly, Utahns are the least likely group to carry more than 1 liter of water. Findings should help further research on risk perception of extreme heat and extreme heat events. Findings should also be useful to land managers in hot and arid climates in developing targeted messaging campaigns designed to engage visitors in protective behaviors. 


\section{PUBLIC ABSTRACT}

Dry heat among the red rocks: risk perceptions and behavioral responses to extreme heat among outdoor recreationists in southeastern Utah

\section{Kirsten M. Goldstein}

Communicating the risks related to extreme heat is important and essential for saving lives. This study looks at how tourists think about extreme heat in a hot and dry environment. It looks at relationships between an individual's local climate, their thoughts about the current weather conditions, and demographics. The results from this study are intended to help tourist agencies, emergency managers and emergency planners, and policymakers in creating and carrying out communication strategies for extreme heat.

Thoughts about and physical responses to weather are different for everyone and shaped by personal experiences. How one thinks and feels about the weather is influenced by a lifetime of personal experiences, unique to each person. However, the connection between an individual's experience and that of his/her understanding of weather-related risk, more specifically risk in extremely hot conditions, has yet to be studied. From 1988 to 2017 extreme heat events have killed more people in the US than any other weatherrelated hazard (i.e. tornadoes, floods, hurricanes, etc.). By understanding how an individual perceives weather conditions, we can begin to better understand best practices for communicating the risks of extreme heat with the intent of saving lives.

There are three primary findings from this study. First is that visitors were likely to overestimate the temperature when it was cooler, but underestimate the temperature when it was hotter. Second, risk perceptions of visitors did not increase during hotter days. Lastly, visitors were not more likely to perform protective behaviors, such as checking the 
weather or carrying water, on hotter days. If extreme heat conditions do not influence visitors' behaviors, they are placing themselves more at risk to extreme heat exposure. 


\section{ACKNOWLEDGMENTS}

I would like to thank my major advisor Dr. Peter Howe for his unwavering support, feedback, and wise advice as I brought all the pieces of this study together and grew through this process. I am grateful to my committee members Dr. Courtney Flint and Dr. Jordan Smith as they provided timely feedback, insights, and encouragement throughout this process. I also would like to thank my lab mates for bouncing ideas around with me and supporting my work.

Financial support was provided through a National Science Foundation grant, including a fellowship in the Climate Science Adaptation (CAS) program. Dr. Nancy Huntly and CAS provided me with an opportunity to work with a research facility in Moab, Utah in order for this study to be feasible. United States Geological Survey (USGS) researcher, Dr. Sasha Reed, provided incredible support and much needed connections with relevant federal agencies, truly making this study possible. The Bureau of Land Management and the National Park Service for their timely approval of my permits. The Rangers I meet while surveying for being excited about the work and coordinating with me when I was surveying.

I am deeply grateful for the support of my family and friends throughout my time in academia. I would like to thank my undergraduate advisor Dr. Mark Lawrence for recognizing the geographer in me before I saw it in myself. My parents, Russell and LuAnn Goldstein, for always believing I could finish this degree and coming to take care of me post ankle surgery. My brothers, Lieutenant Louis Goldstein and Dr. Rutherford Goldstein, for always balancing the support, criticism, and coaching with ways to get me

to laugh through it all. My friend Diana Chambers, a fellow geographer and my unofficial 
editor, for looking at various drafts of my work for more than two years. All my friends who listened to my ramblings and frustrations as I plowed through it all. Your love and support mean everything to me.

A simple 'thank you' cannot express the true level of my gratitude to everyone who has been there for me along the way.

Kirsten Goldstein 


\section{CONTENTS}

ABSTRACT .iii

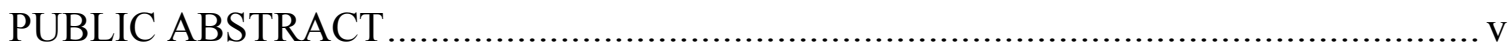

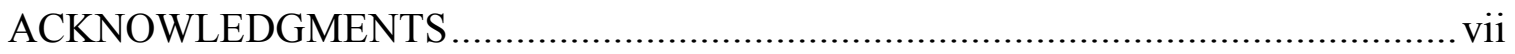

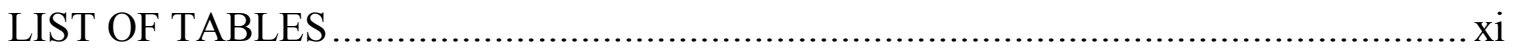

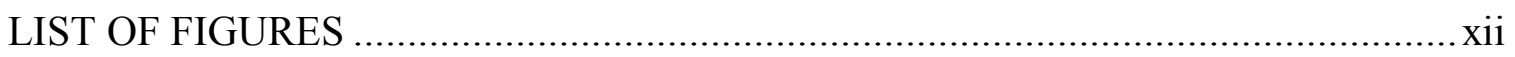

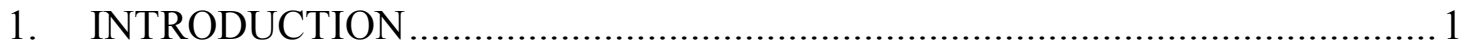

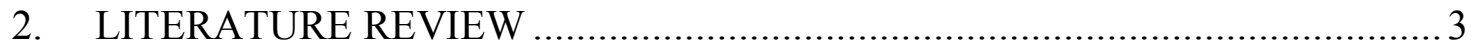

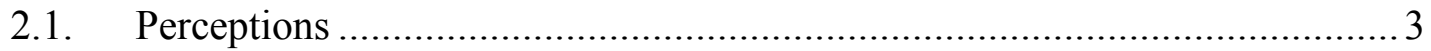

2.2. Tourism and climate change............................................................ 6

2.3. Risk studies and behavioral frameworks........................................... 8

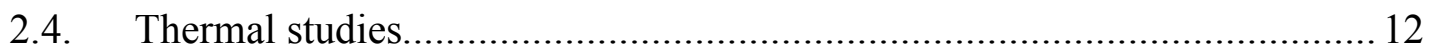

2.5. Tourism and thermal perceptions ................................................. 14

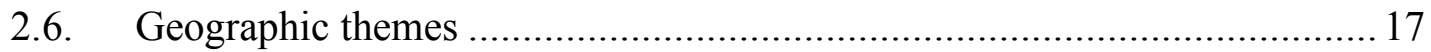

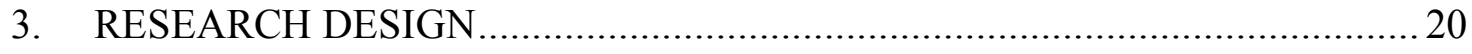

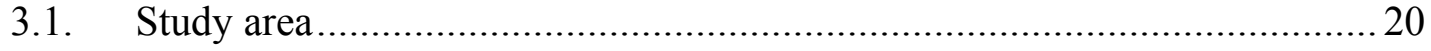

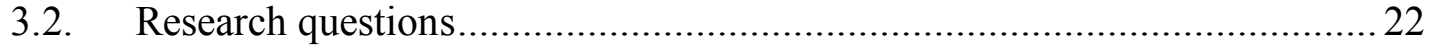

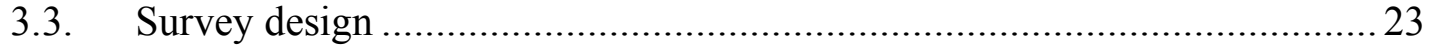

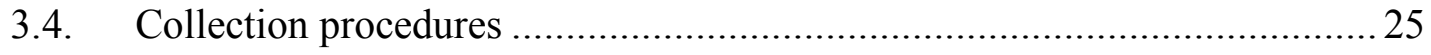

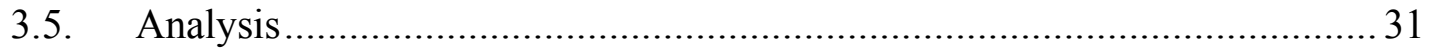

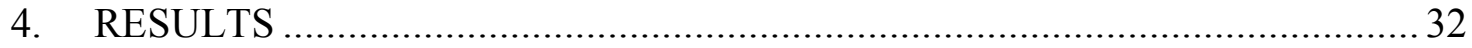

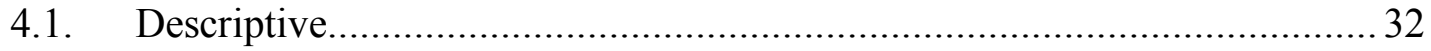

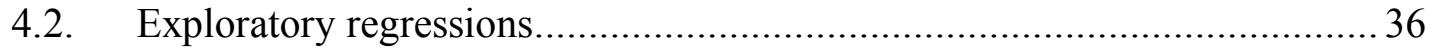

4.3. Linear mixed-effect models........................................................... 37

4.4. Generalized linear mixed-effects models ............................................. 38

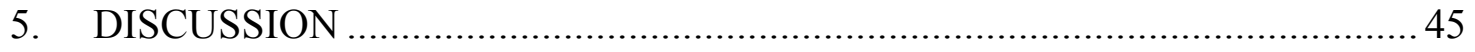

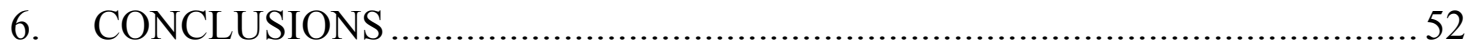

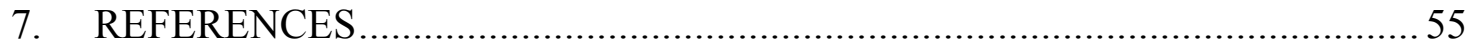

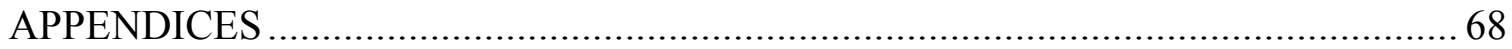

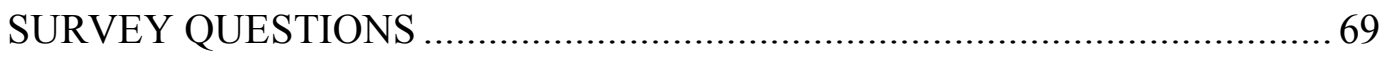

SURVEY WITH LETTER OF INFORMATION FOR PARTICIPANTS ......... 73

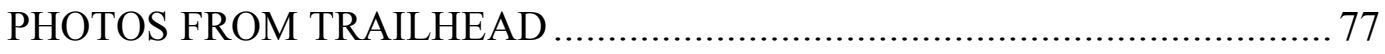

LINEAR MIXED-EFFECT MODELS ................................................... 78 
GENERALIZED LINEAR MIXED-EFFECT MODELS............................... 81

RANDOM EFFECTS ODDS RATIOS - RISKP ......................................... 84

RANDOM EFFECTS ODDS RATIOS - CHECK THE WEATHER ................8 88 


\section{LIST OF TABLES}

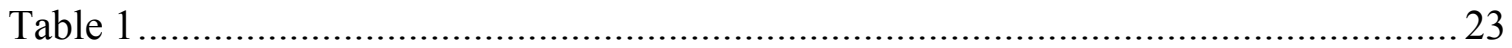

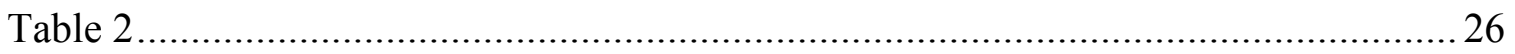

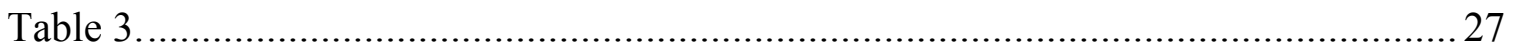

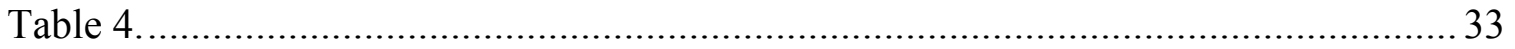

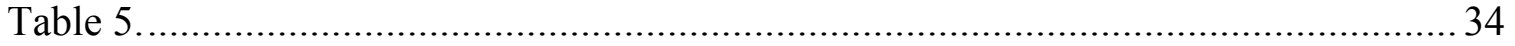

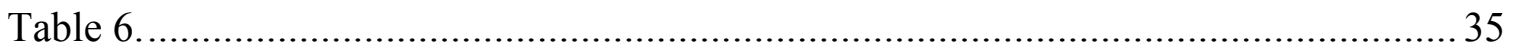

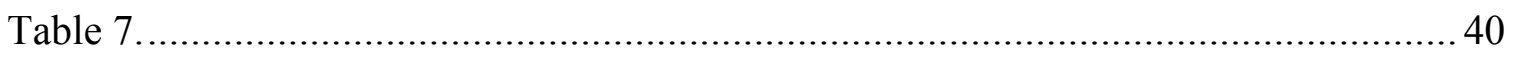

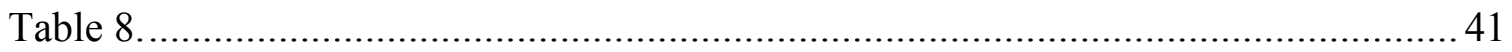

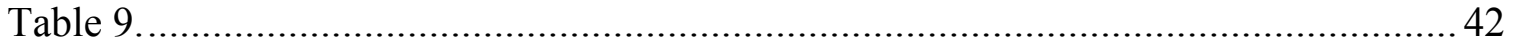

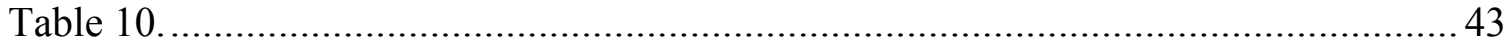

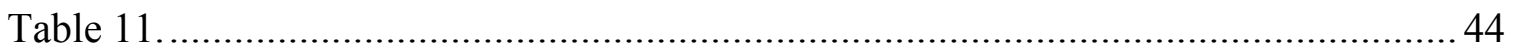




\section{LIST OF FIGURES}

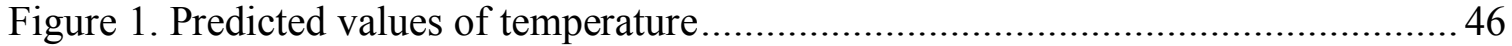

Figure 2. Random effects of age on risk perception ............................................. 48

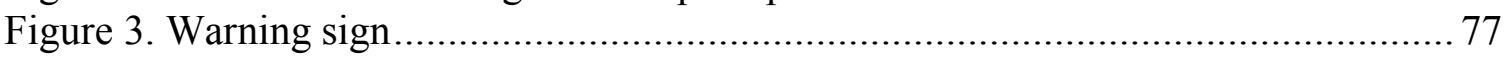

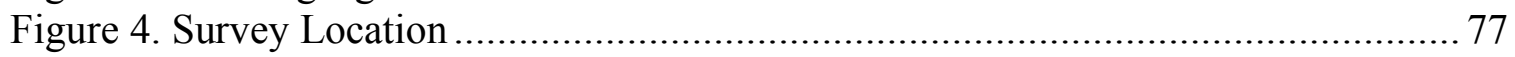




\section{INTRODUCTION}

In this thesis, I explore themes of geography in order to explain variations in risk perceptions of extreme heat at a popular tourist destination. Risk perceptions of extreme heat is an understudied area of research, as the subject matter falls at the intersection of many different disciplines. Here geography is used to examine how people operate in and interact with a specific environment and how these interactions could influence various outcomes, including risk perceptions and behaviors. Risk perceptions of both heat waves and extreme heat are important to explore because heat is a major global hazard that can cause severe and fatal physical responses in the human body (Mora, Counsell, Bielecki, \& Louis, 2017; Toulemon \& Barbieri, 2008). However, if people have a proper awareness of the hazard they are likely to take protective actions with the purpose of reducing their risk to the hazard.

Heat waves are expected to increase in severity and frequency due to climate change (USGCRP, 2018), and the areas likely to experience extreme heat are expanding, exposing more people to heat-related health risks (Jones et al., 2015; Kharin, Zwiers, Zhang, \& Hegerl, 2007; Mora, Dousset, et al., 2017; Schwartz et al., 2015). Even under current climate conditions, extreme heat events are the deadliest weather-related hazard in the US; between 1988 and 2017, heat events have caused more direct deaths than any other natural hazard (McGeehin \& Mirabelli, 2001; NWS, 2016, Sheridan \& Dixon, 2017). Mean temperatures around the world will increase under a range of plausible climate scenarios, and conditions are expected to get drier (USGCRP, 2018). Although risk perceptions of heat waves have begun to be studied at a national scale (Howe, Marlon, Wang, \& 
Leiserowitz, 2019), it is not well understood how risk perceptions vary within populations that do not regularly experience the climate in a specific place, such as tourists.

In order to effectively communicate the risks of heat, it is important to understand perceptions of extreme heat and what factors influence those perceptions. Many authors (Bubeck, Botzen, \& Aerts, 2012; Grothmann \& Patt, 2005; Lindell \& Perry, 2012) lay out frameworks and models as to how people process information and then protect and adapt to natural hazards or climate change. Bubeck et al. (2012) presents a schematic overview of protection motivation theory; then suggests that a sole focus on one component, risk awareness rising, could potentially lead to non-protective behavioral responses. A common theme across all of the behavior models and frameworks reviewed in this literature review is that perceptions play a key role in influencing behaviors. While perceptions are a part of every model and behavior framework, how perceptions vary across populations is understudied.

In order to further our understanding of perceptions, I examine the thermal perceptions and risk perceptions of visitors to two popular recreation trails in the Moab, Utah area, in the southwestern United States. Since this region experiences heat related illness and death annually (“"100 percent avoidable,”" 2016; “Heatstroke and Heat Exhaustion," n.d.; "Keeping your cool in summer," 2013; "Man found dead at Arches," 2016; “Woman found dead at Arches,” 2016; KUTV, 2017; Schums, 2018; Stilson, 2017), a study of visitors' risk perceptions and behaviors should be helpful for local outdoor recreation management agencies, public health officials, and emergency responders to more effectively communicate the risks of extreme heat before a dangerous heat event, and to identify characteristics of visitors potentially more at risk. 
This thesis begins with a review of the literature focusing on thermal perceptions, thermal sensations, and risk perceptions. Next, I present research questions on how thermal perceptions, thermal sensations, and risk perceptions may or may not relate to one another, or influence behaviors. I then address these questions using survey data I collected from visitors at two popular recreation trails in the Moab, Utah area. Finally, I conclude with some general implications for how this information could be used by local outdoor recreation management agencies (the National Park Service, the Bureau of Land Management, etc.), public health officials, and emergency responders.

\section{LITERATURE REVIEW}

This section begins by reviewing literature about how thermal sensations, thermal perceptions, and risk perceptions relate to each other. Next this section explores how a changing climate will increase extreme heat and impact weather dependent tourism destinations. Third, it examines how perceptions influence behaviors through behavioral frameworks and previous studies on risk perceptions. Then it looks at how thermal perception studies explore differences across geographies and discusses tourist based thermal perception studies. Finally, this section concludes with why geography is important in heat risk perception studies.

\subsection{PERCEPTIONS}

Experiences and contexts shape a person's physiological and cognitive responses to ambient temperatures (Yin et al., 2012). These responses influence a person's thermal perception and thermal sensation of current weather conditions. Thermal perception is a cognitive response, built from experiences in the environment, it is how one thinks about 
the weather. Thermal sensations are physiological responses to something that comes in contact with the body (i.e. heat, sun, wind, etc.). It has generally been understood that thermal perceptions and thermal sensations contribute to an individual's thermal experience in a given environmental situation. However, the connection between an individual's thermal experience and risk perception of weather, more specifically extreme weather (i.e. extreme heat), is yet to be fully explored. Risk perceptions are subjective judgments based on the characteristics of a risk or hazard, and the potential threat it poses to one's self, but can differ from the objective risk assessment of a hazard (Rohrmann \& Renn, 2000). Risk perception can also refer to a combined measurement of perceived probability and perceived consequences; what is the perceived likelihood of being affected by the hazard, and what is the perceived consequence of being affected by the hazard (Bubeck et al., 2012).

Thermal perceptions are assembled from acquired knowledge and the assimilation of thought, senses, and experiences throughout one's life (Lin, 2009; Nikolopoulou, Baker, \& Steemers, 2001). Experiences include previous thermal exposures and sensations: a cold winter day or a humid summer day. On the other hand, a thermal sensation is a physiological response to what the body is in contact with (i.e. heat, sun, wind, etc.). A current or immediate physiological response, is a culmination of all previous thermal experiences; the more exposure to a certain weather condition or temperature, the more acclimated one is to the particular conditions related with that weather. In other words, one's current thermal sensation is greatly influenced by previous exposures to similar or different conditions. This is understood as a person's thermal history. Thus, thermal history constructs thermal sensations, which in turn impacts thermal perceptions. 
Numerous studies have documented the relationship between thermal sensations and thermal perceptions (Höppe, 2002; Kántor, Kovács, \& Takács, 2016; Knez, Thorsson, Eliasson, \& Lindberg, 2009; Lin, 2009; Ng \& Cheng, 2012, 2012; Rutty \& Scott, 2015; Spagnolo \& de Dear, 2003). Moreover, thermal perceptions show a strong link to thermal history, thermal expectations, and thermal sensations (Chen \& Ng, 2012; Nikolopoulou et al., 2001). In the same vein, risk perceptions are also established through cognitive and subjective judgements based on the probability, characteristics, and concern one has for the consequences of a risk or hazard (Rohrmann \& Renn, 2000). Perceptions are important elements to study in hazards research as they contribute to decision making and behaviors in individuals (Bubeck et al., 2012; Grothmann \& Patt, 2005; Lindell \& Perry, 2012; Wachinger, Renn, Begg, \& Kuhlicke, 2013). However, there has been little research examining the connection between thermal perceptions and an individual risk perception of extreme weather (i.e. extreme heat).

While risk perceptions and thermal sensations are subjective and are the result of accumulated individual experiences, the effects of heat waves and extreme heat have tangible physiological impacts. In this context, extreme heat is severe and excessive heat, usually associated with a combination of high temperatures and high humidities relative to the typical or expected weather for an area at that time of year. Extreme heat can be considered a heat wave, or extreme heat event, if the period of unusually hot weather lasts 2 or more days (NWS, n.d.). Extreme heat events are a major weather-related health hazard (Mora, Dousset, et al., 2017) that are experienced around the world. For example, excess deaths of thousands of people during the 2003 European and 2010 Russian heat waves illustrate the major risks associated with humans' limited thermoregulatory capacities 
(Barriopedro, Fischer, Luterbacher, Trigo, \& Garcia-Herrera, 2011; Grumm, 2011; Poumadère, Mays, Le Mer, \& Blong, 2005; Toulemon \& Barbieri, 2008). Capacities are reached when conditions are too hot, too humid, or both, for the human body to dissipate heat. This prompts physiological responses to cool down (Mora, Counsell, et al., 2017). Human bodies respond in two key ways. One, blood vessels dilate to redirect blood from the core to the periphery dissipating heat to the environment, subsequently reducing blood flow to organs. Two, the body's temperature can exceed cells' tolerance, leading to cell breakdown. Both of these bodily responses lead to cell death and break down the integrity of cell membrane (Mora, Counsell, et al., 2017). Furthermore, these physiological responses are not unique to a single group of people (such as the elderly or sick). These reactions happen in all human bodies (Mora, Counsell, et al., 2017). Despite the seriousness these consequences pose from heat exposure, people are still inadvertently exposed to extreme heat; those particularly at risk include the elderly, those living alone, those without access to cooling, those who are homeless, or outdoor workers (Kuras, Hondula, \& BrownSaracino, 2015). Yet even still, people do make the choice to expose themselves to extreme heat situations, such as by visiting nature-based tourism destinations known for being hot or during hot weather. Death Valley National Park, for example, is a tourism destination in part because it is the site of the highest ambient air temperature recorded on Earth (El Fadli et al., 2013).

\subsection{TOURISM AND CLIMATE CHANGE}

Since nature-based tourism is highly weather dependent, understanding visitor perceptions of destinations will be crucial for economically sustainable tourism destinations (De Urioste-Stone, Scaccia, \& Howe-Poteet, 2015). Among all economic 
sectors, tourism is considered one of the most vulnerable industries to climate change given it often utilizes unique natural resources to attract tourists (Lépy et al., 2014). Results from a 2015 study conducted in Acadia National Park indicate that a majority of visitors are concerned with the negative effects that unpredictable weather may have on the region (De Urioste-Stone et al., 2015). A primary factor that determines the desirability of weather and climate is temperature. Extracted results from emission scenarios show that many current tourism destinations will suffer from the various effects of climate change, primarily a change in predicable weather conditions from season to season (Matzarakis, 2006). Knowledge of thermal climates can be helpful not only for existing and planned tourist destinations, but also in providing information about where and when weather and climate may negatively affect tourists (Matzarakis, 2006). This knowledge could significantly impact the future of local economies that rely on tourism based income.

Current climate change research demonstrates that between now and the year of 2100 three elements of heat waves in the United States will increase: frequency, severity, and area of impact (Kharin et al., 2007; Schwartz et al., 2015; USGCRP, 2018). While there is no single definition of a heat wave, the widely accepted definition is a period of abnormally high temperatures lasting two or more days, measured relative to the normal temperatures for that particular season and location (Basu \& Samet, 2002; NWS, n.d.; Smith, 2013). Temperatures considered normal in a hotter climate could be termed a heat wave in a cooler climate if the length and temperature of the event are outside the normal or expected climate pattern for that area and time of year. Additionally, night time temperatures typically do not fall as much as normal during a heat wave, thus intensifying the overall effect of the abnormally high temperatures. During heat waves, impacted areas 
will often experience excessive death rates due to heat induced illnesses (Basu \& Samet, 2002; Toulemon \& Barbieri, 2008). Warmer temperatures and drier conditions will continue to increase around the world under current emission scenarios (Kharin et al., 2007; Mora, Dousset, et al., 2017).

Within the United States, both southern and northern cities are expected to see an increase in heat wave events, exposing less adapted populations to more deadly conditions (Basu \& Samet, 2002; Bobb, Peng, Bell, \& Dominici, 2014; Lopez et al., 2018; McMichael, Woodruff, \& Hales, 2006; Meehl et al., 2000). There has recently been a decline in heatrelated deaths in northern cities; this is understood as a result of catching-up to southern cities' coping and adaptation strategies (Bobb et al., 2014). However, these adaptations in northern cities have been mostly structural, such as a higher prevalence of air-conditioning. Even under current climate conditions, extreme heat events are the deadliest weatherrelated hazard in the US, causing more direct deaths than any other hazard over the past 30 years (McGeehin \& Mirabelli, 2001; NWS, 2016, Sheridan \& Dixon, 2017). Because extreme heat events are so deadly and their severity and frequency are projected to increase, an understanding of the risk perceptions associated with extreme heat is urgently needed. Through a greater understanding of risk perceptions that informs risk communication, more lives can be saved in extreme heat conditions.

\subsection{RISK STUDIES AND BEHAVIORAL FRAMEWORKS}

Natural hazards research falls at the intersection of fields such as human geography, physical geography, geographic information systems, public health, anthropology, sociology, and psychology (Montz \& Tobin, 2011a). It is therefore in a unique position to understand how contexts and experiences impact individual perceptions. Historically, 
research on risk perceptions of natural hazards has focused on perceptions of geophysical hazards like volcanoes, earthquakes, and landslides (Bolin \& Stanford, 1998; Jóhannesdóttir \& Gísladóttir, 2010; O’hare \& Rivas, 2005) and perceptions of meteorological hazards like tornadoes and floods (Simmons \& Sutter, 2011; Wallace, Poole, \& Horney, 2016). Perceptions are important to hazard research since most people will make decisions in part based on their personal assessment of a threat. This makes perceptions important elements to consider in risk management and risk communication (Bubeck et al., 2012; Grothmann \& Patt, 2005; Lindell \& Perry, 2012). The distinction is that perceived risk is subjective and can differ from expert risk assessments. Yet, risk perceptions of heat waves and extreme heat are relatively understudied, likely a result of how this particular natural hazard intersects with environmental health fields. This has resulted in the absence of robust literature on risk perceptions of extreme heat.

A wide range of data are available on weather, climate, land use, and land cover, ranging in scale from the neighborhood to the continent. Additionally, considerable data exist on socioeconomic attributes that predict vulnerability to heat mortality due to extreme heat (Reid et al., 2009). Combined, these data can be used to generate total vulnerability indices to extreme heat, which have been mapped on the regional and neighborhood scales (ESRI \& NOAA, 2016; Harlan, Brazel, Prashad, Stefanov, \& Larsen, 2006; Reid et al., 2009; Son, Lee, Anderson, \& Bell, 2011). Although these data reveal important relationships between physical and social vulnerability, they do not capture individual risk perceptions of extreme heat. This is an important component of vulnerability to hazards, and in particular weather related hazards (Bubeck et al., 2012; Grothmann \& Patt, 2005; 
Lindell \& Perry, 2012) and is the next step to understanding how people make decisions under extreme heat or natural hazard conditions (Morgan \& de Dear, 2003).

Bubeck et al. (2012), Grothmann and Patt (2005), and Lindell and Perry (2012), all lay out frameworks and models of how people process information, make decisions, and then protect themselves and adapt to a natural hazards or climate change; and all of them include perceptions as part of the framework or model. Bubeck et al. (2012) includes perceptions of the actual threat, in their case flooding, and perceptions of coping abilities in order to determine the coping response of people and communities. Lindell and Perry (2012) also include threat perceptions, and protective action perceptions, but also stakeholder perceptions. Stakeholders are defined as government authorities, scientific evaluators, watchdogs (e.g. media, environmental groups, citizens), and industry/employers. Lindell and Perry found these important to include in their Protect Action Decision Model as stakeholders can hold power over other's decisions to adopt hazard adjustments. Grothmann and Patt (2005) include perceptions in their model of private proactive adaptation to climate change in a number of ways, such as in perceptions of adaptive incentives and adaptive capacity. Also included in their model were perceptions about social discourse on climate change risk and adaptation, and the perceived probability and perceived severity about climate change risk. Regardless of how perceptions are included in each of these frameworks or models, it is clear that perceptions play an integral role in understanding the decision-making process of humans when confronted with climate change or a natural hazard.

Slovic and Peters (2006) describe how humans perceive and act on risk in two ways: one way is intuitive, automatic, natural, nonverbal, experiential; and the other way is 
analytical, deliberative, and verbal. The first way is instinctive and the second way uses logic and reason in the decision making process. Slovic and Peters explain that people judge a risk not only by how they logically think about the risk, but also by how they feel about the risk. For example, if one's feelings towards and activity is favorable, one will tend to judge risks associated with the activity as low and the benefits as high. The opposite is also true; if one's feelings toward the activity are unfavorable, the risk associated with it will be high and the benefits low. If feelings towards an activity guide perceptions about that activity, then by providing information about the risks and benefits of that activity, one's perceptions should change. According to the frameworks described above, then this should also change one's behavior and act in a more protective manner. In the case of risks related to heat, it may be difficult to gauge the range of feelings humans have about the risk, because in contrast to other hazards such as hurricanes or earthquakes, heat is a frequently experienced phenomenon for most people. Hot weather occurs typically during certain seasons across most of the world, yet hot weather does not always constitute a hazard. The extent to which hot weather becomes hazardous depends both on the weather itself and the vulnerability of people who are exposed to it. Due to the regularity that humans experience heat, people may see the phenomenon as normal without distinguishing particular feelings about extreme heat as a hazard. With this in mind, it makes it difficult to judge people's feelings toward heat as a hazard, and thus their risk perceptions.

A few studies on heat risks perceptions have focused on populations considered the most vulnerable, such as elderly or those in cities. A study conducted in nursing homes in London and Norwich in the United Kingdom, found that residents do not perceive heat as a risk to their health, despite evidence to the contrary (Abrahamson et al., 2009). Another 
study examined the efficacy of heat watch warning systems in four North American cities (Sheridan, 2007). The study included a survey of residents in the metropolitan areas to measure their perception of their own vulnerability to heat. It found that many respondents believe they are not vulnerable to heat, or that the weather is not hot enough. One more study looked at heat-related health inequalities within Phoenix, AZ to order to understand the relationships between the microclimates of urban neighborhoods, population characteristics, and the resources people possess to cope with climatic conditions (Harlan et al., 2006). Lower socioeconomic and ethnic minority groups were more likely to live in warmer neighborhoods with greater exposure to heat stress, leaving them more vulnerable to heat exposure because they had fewer social and material resources to cope with extreme heat.

\subsection{THERMAL STUDIES}

Other studies have focused less on specific heat risk perceptions but on thermal perceptions in predominantly hot places or during hot seasons. Many studies have been conducted in indoor or urban settings, specifically examining perceptions in office spaces or urban public spaces respectively (Chen \& Ng, 2012; Kántor et al., 2016; Kuras et al., 2015, 2015; Pearlmutter, Jiao, \& Garb, 2014; Yin et al., 2012). These studies are valuable for clarifying key components of thermal perceptions, yet they are not specifically designed to understand heat risk perceptions. Evidence from thermal perception studies demonstrate that perceptions are highly influenced by thermal history and recent thermal sensations (Brager \& de Dear, 1998; Chen \& Ng, 2012; Lin, 2009; Yin et al., 2012). Each person psychologically and physiologically perceives and responds to heat differently. Brager and de Dear (1998) suggest that how someone expects to experience their environment greatly 
impacts how one actually does experience the environment. People create their own thermal preference through the way they interact with the environment and gradually adopt their expectations to match the thermal environment. Thus, one's comfort in an environment is influenced by people's expectations of the thermal environment.

Another study looked at systematic patterns of how different people experience the environment differently. For example Morgan and de Dear (2003) found that women in a six month shopping mall study wore marginally heavier clothing than men. Using a value based on the amount of clothing worn, an insulation value, women showed a greater variability in their insulation values that could be explained by variations in mean daily outdoor temperatures. Morgan and de Dear suggest a fundamental difference in clothing norms and behaviors between men and women; men over 30 years of age will typically wear pants, while women of all ages will wear skirts, shorts, or dresses in hot weather. This gender difference gives the impression that women have a heightened temperature sensitively, reflected in their clothing patters compared to males. Both of these elements, how one expects to experience the environment (Brager \& de Dear, 1998) and one's sensitivity to the environment (Morgan \& de Dear, 2003) is a possible product of where one grew up, or currently lives. This suggests that heat risk perceptions could vary based on one's geographic and demographic characteristics (Basu \& Samet, 2002; Kántor et al., 2016; McGeehin \& Mirabelli, 2001; Sawka, 2015; Shen \& Zhu, 2015).

Regional climate and cultural variation in temperature controlled spaces lead to differences in experiences of indoor and outdoor ambient temperatures; which in turn affects one's thermal sensations of their environment (Hitchings, 2011). These differences have led scholars to investigate what contributes to a sense of a thermal 'neutral' 
temperature, and why it varies among people (Chen \& Ng, 2012; Hitchings, 2011; Lin, 2009). For example, compared to people in other Asian cities of similar tropical climates, the people of Hong Kong have a lower 'neutral' temperature; they are more sensitive to outdoor heat precisely because of heavy air conditioning use keeping them cool in controlled environments (Hitchings, 2011). Indeed, much of the world's population spends a great deal of time in controlled temperatures (Kuras et al., 2015; Morgan \& de Dear, 2003), exposing us less to our outdoor climates. Scholars have highlighted geographic variation in preferred 'neutral' temperature to suggest more regionally specific indoor thermal standards, which could reduce energy usage in areas where cooling or heating is necessary (Dear \& Brager, 2001; Hitchings, 2011).

Incidentally this regional difference in a preferred 'neutral' temperature allows us to interpret regional differences in how people from different places think about and react to various environments (Hitchings, 2011). Through this research, thermal standards for indoor settings and many public spaces have been made available, but these thermal standards are not available for a range of outdoor settings, such as public recreation areas (Höppe, 2002). A greater understanding of risk perceptions and thermal sensations based on geographic characteristics and thermal histories could lead to better communication strategies about heat related hazards (Lin, 2009; Yin et al., 2012).

\subsection{TOURISM AND THERMAL PERCEPTIONS}

While studies stress that perceived risk influences a person's overall vulnerability (Akompab et al., 2013; Jóhannesdóttir \& Gísladóttir, 2010; Lujala, Lein, \& Rød, 2015; Wachinger et al., 2013), few studies have investigated heat risk perceptions in the US (Howe et al., 2019). Furthermore, no study has specifically investigated heat risk 
perceptions in tourist populations. Since tourist populations do not regularly experience the climate of their destination, heat risk perceptions can be even more difficult to gauge. Visitors can experience additional vulnerability to extreme weather since they are less acclimatized to their new surroundings. Their thermal perceptions are formed in different environments, leading to differing thermal histories and this may cause them to be less informed about what protective actions to take to best protect themselves from extreme heat.

While this is an understudied area of research, there are some studies that begin to look at how thermal perceptions could vary based on one's geographic origin. A study conducted in outdoor and semi-outdoor locations in subtropical Sydney, Australia ( $n=$ 1,018 ), found a correlation between a tourist's region of origin could influence what people perceived the actual temperature to be (Spagnolo \& de Dear, 2003). Another outdoor thermal comfort study conducted during the warm season at the Melbourne, Australia Royal Botanic Garden $(n=2,198)$ found that overseas tourists have different comfort perception and preferences compared to local Australian visitors (Lam, Loughnan, \& Tapper, 2016). The difference in perceptions demonstrates that overseas tourists were less acclimatized to the extreme heat conditions of Melbourne in summer. In this study Australian visitors felt cooler than Chinese and European tourists, possibly due to acclimatization of their local Australian weather (Lam et al., 2016; Nikolopoulou et al., 2001). Another study conducted on several Caribbean beaches in the islands of Barbados, Saint Lucia, and Tobago $(n=472)$, found that perception of outdoor microclimate conditions in a coastal environment varied between everyday users of the space and tourists on vacation (Rutty \& Scott, 2015). These studies, and others, have highlighted that there 
are differences in visitors' perceptions of weather and climate depending on their place of origin (Chen \& Ng, 2012; Lam et al., 2016; Lin, 2009; Mahmoud, 2011; Nikolopoulou et al., 2001; Spagnolo \& de Dear, 2003).

Although some data on tourists' thermal perceptions has been collected in rural outdoor environments (Akompab et al., 2013; Lam et al., 2016; Rutty \& Scott, 2015), this literature review did not uncover any research published on the heat risk perceptions of visitors to outdoor recreation areas in the southwestern United States. The southwestern United States, including Arizona, Colorado, Nevada, New Mexico, Utah, and parts of southern California, receives many international and domestic visitors (Moab \& Us, 2017; Schums, 2018). This region is home to many highly visited national and state parks, monuments, preserves, outdoor recreation areas, and other public lands. Landscapes in these sites are primarily arid and experiences extreme summer heat. Notable tourist sites include: Arches National Park (NP), Grand Canyon NP, Death Valley NP, and Zion NP. This region has also experienced progressively higher visitation rates every year (Moab \& Us, 2017). In 2013, there were nearly 1.1 million visitors to Arches National Park (NP), followed by 1.3 million, 1.4 million, and 1.6 million in the subsequent years. In the same years visitation to Grand Canyon NP was 4.5 million, 4.7 million, 5.5 million, and 6 million. Every year these national parks respond to heat-related illnesses and heat-related fatalities of visitors (“"100 percent avoidable,"” 2016; "Heatstroke and Heat Exhaustion," n.d.; "Keeping your cool in summer," 2013; "Man found dead at Arches," 2016; "Woman found dead at Arches," 2016; KUTV, 2017; Schums, 2018; Stilson, 2017). The rapid growth in visitation has increased the number of people at risk of extreme heat exposure. 
A possible reason why this area experiences high heat mortality and morbidity could be due to a lack of acclimatization by visitors to the hot and dry environment.

To further understanding of visitors to a hot and arid environment, two heat acclimatization studies inspected thresholds of biological adaptations in high performance athletes in warm to hot environments (Sawka, 2015; Sawka, Leon, Montain, \& Sonna, 2011). Findings show that it takes 1-2 weeks of daily 90-minute exposures to heat stress for athletes to acclimatize to high heat environments. This acclimatization to heat can improve comfort, increase exercise capacities, reduce physical strain, and reduce risks of serious heat illness during exposure to heat stress (Cheuvront, Kenefick, Montain, \& Sawka, 2010; Sawka, 2015). Of course, most tourists are not high-performance athletes, yet every year, tourists engage in strenuous activities, such as hiking, in hot environments, that are perhaps beyond their typical physical expenditure. However, some will not perform the necessary adaptive behaviors to ensure their health and safety; this generates a higher potential for vulnerability (A. Schums, personal communication, December 16, 2018). With the rapid growth in visitation, the number of people at risk to extreme heat exposure has increased. Not only is understanding visitors' perceptions at tourist destinations useful for tour planning, marketing, and agencies that manage the destinations (Freitas, 2003; Lam et al., 2016), understanding visitors' perceptions could save lives by improving communication and response efforts to the diversity of tourists visiting the region.

\subsection{GEOGRAPHIC THEMES}

The discipline of geography has no single universal definition. However, one possible definition is "the study of the ways in which space is involved in the operation and outcome of social and biophysical processes" (Gregory, Johnston, Geraldine, Watts, \& 
Wathmore, 2013, p. 288). Geography has no single method of enquiry. However, geographic sub-disciplines examines how outcomes of processes differ from place to place in various ways. In the case of the subdiscipline of human geography, its research methods explore how "place, space, and environment influence the operation and the outcome of social processes and human activities" (Gregory et al., 2013, p. 350). This thesis explores how the operations of people from different places may differ in the same environment. This thesis also explores how the environment influences people and their behaviors, which is a key question addressed by the sub-discipline of human-environment geography. This thesis in particular explores how humans interact with the environment when the environment itself is a hazard for humans.

Geography has a long tradition of research on environmental and natural hazards, which examines both the risk of a potential event and the degree to which people are likely to suffer if they experience an event (Colten \& Sumpter, 2009; Cutter, 1996; Gregory et al., 2013; Montz \& Tobin, 2011a). Here event refers to both natural and weather related hazards. Exploring and examining how people interacted with a potentially hazardous environment is embedded in what geography as a discipline encompasses. The study presented in this thesis adds to the discipline of geography and hazards research by examining how humans feel about and interact with the hazard of extreme heat.

Ultimately, risk perceptions of extreme heat are likely to be influenced by many factors. Perhaps the most prominent factor is to which climate an individual is most acclimatized: there is supporting literature about this factor on thermal perceptions and risk perceptions, yet it remains unclear just how much impact it generates on one's thermal perception and ultimately one's risk perception of extreme heat. This investigation focuses 
on how geographic differences and thermal perceptions are associated with risk perceptions of extreme heat among a population that is becoming increasingly vulnerable: outdoor recreationists to the hot dry climates of the southwestern U.S. 


\section{RESEARCH DESIGN}

The purpose of this study is to understand visitors' thermal perceptions and risk perceptions of extreme heat at a recreation area in southeast Utah where heat related illness and death is a common concern and an unfortunate consequences of unprepared visitors (““100 percent avoidable,"” 2016; "Heatstroke and Heat Exhaustion," n.d.; "Keeping your cool in summer," 2013; "Man found dead at Arches," 2016; "Woman found dead at Arches," 2016; KUTV, 2017; Schums, 2018; Stilson, 2017). This study's objective is to investigate geographic and environmental factors that influence risk perceptions and protective behaviors.

\subsection{STUDY AREA}

In order to gather visitors' perceptions to extreme heat in the area I conducted intercept surveys at two trailheads in the vicinity of Moab, Utah: Corona Arch in Canyon Rims Recreation Area (Bureau of Land Management) and Delicate Arch in Arches NP (National Park Service). This area was selected because of its high volume of tourists in the summer season, and the local agency's ability to host me for a summer season. The following two trails were selected as comparable trails in length, sun exposure, difficulty, and as out-and-back formatted trails.

Corona Arch trail is approximately 2.25 miles round trip with roughly 400 feet of elevation gain. The first half of the trail is gravel and rock, the second half is a marked path on slickrock. Due to part of the trail going through a canyon like section, there is shade at either morning, or late afternoon. Corona Arch trail is rated moderately strenuous by the on the Bureau of Land Management's (BLM) website ("Corona Arch Trail," n.d.). 
Delicate Arch trail is approximately 3 miles round trip with almost 500 feet of elevation gain. Almost the entire trail is exposed rock, while the trail has no shade. While the National Park Service's (NPS) website for Delicate does not give a difficulty rating for the trail, it does write "Rangers frequently rescue people who underestimate the trail's difficulty". Delicate Arch trail is understood to be rated as moderate to strenuous.

Search and Rescue (SAR) in Arches NP has experienced problems related to the variety of people visiting the park and their experience, or lack thereof, with extreme heat. However, it has also been hard for the park to justify procedural changes because it is not always clear exactly how many SARs per year are related to heat (A. Schums, personal communication, December 16, 2018). In order to understand how difficult it is for the park to manage for inexperienced hikers and visitors, it is necessary to understand how statistics on SAR operations are reported and recorded. First, to get simple statistics from the reports, i.e. "how many reports this year occurred at trail A", the commanding SAR officer has to open each filed report individually and keep count. And second, within the reports, the level of detail varies widely between the reporting officer. Additionally, there were 27 unfinished reports for the 2018 calendar year as of December of 2018 (A. Schums, personal communication, December 16, 2018). Many of the SAR reports that can be clearly linked to heat report either "insufficient prep" for the hike, "not drinking water", "fatigue", "dizzy", "poor physical condition" of the hiker, or a pre-existing health condition (e.g. diabetes).

Arches NP has put in place two preventative measures to decrease the number of SARs. The first is more restrictions on tour buses. Each bus needs an additional permit to hike specific trails. Second, the park recently introduced a preventative SAR program that 
has seen a subjective decrease in the number of incidences reported. This decrease is considered subjective because there is no clear reporting on the number of incidents per year before the preventative SAR program, and the number of incidents per year after the program's implementation. This program places an internship-based ranger at the trailhead of popular trails. This ranger then chats with hikers as they head out to see if they understand how long the trail will take them, and if they are carrying enough water. Officers who have worked at the park before and after the two programs' implementations believe they have made a difference in the number of SARs (A. Schums, personal communication, December 16, 2018).

It is important to note that due to the different structures of the two governing agencies of these lands, and the difference in visitation to the respective trailheads, it is very difficult for BLM to implement similar programs at Corona Arch trailhead. Search and Rescue information strictly related to BLM or Corona Arch is not readily available.

\subsection{RESEARCH QUESTIONS}

The research questions for the study are as follows:

1) What is the relationship between thermal perception, thermal sensations, and instrumental records in a hot and arid outdoor environment?

a. How do instrumental records and acclimatization relate to thermal perception and thermal sensations?

b. How do geographic attributes (place of residence) relate to thermal perception and thermal sensations?

2) How do thermal perception and thermal sensations relate to heat risk perceptions? 
a. Do thermal perception and thermal sensations predict heat risk perceptions after controlling for geography and demographics?

b. Do geographic attributes predict heat risk perceptions after controlling for thermal perception, thermal sensations and demographics?

3) Do risk perceptions predict heat protective behavior?

\subsection{SURVEY DESIGN}

In order to make this study comparable to other thermal perception and thermal sensation studies, the survey was designed using similar or standardized questions (Johansson, Thorsson, Emmanuel, \& Krüger, 2014; Lai, Guo, Hou, Lin, \& Chen, 2014; Lam et al., 2016; Lin, 2009; Ng \& Cheng, 2012; Rutty \& Scott, 2015; Yin et al., 2012). Conceivably, standardization will allow this study to be of value to future studies of similar design. This survey was pilot tested in April 2018 on Utah State University's campus. The pilot intended to test the wording of the survey and receive feedback on the instrument's design and interpretability. Minor edits were made to enhance flow of the questions and the survey overall. The questions included in the survey, the possible answers, and explanations for why they are included in appendix A. Below, Table 1, lays out the variables that were included in the final models, the questions, and possible answers associated with that variable.

Table 1

Survey questions

\begin{tabular}{|l|l|}
\hline Name of variable & Question \\
\hline Geographic attribute & Where do you currently live? \\
\hline City, town or country, State or province, ZIP or postal code, Country \\
\hline Thermal perceptions & What do you think the outside temperature is right \\
\hline
\end{tabular}




\begin{tabular}{|c|c|}
\hline & now? \\
\hline \multicolumn{2}{|c|}{ An X placed on a thermometer (Fahrenheit and Celsius) } \\
\hline Thermal sensation & $\begin{array}{l}\text { How does the current temperature compare to } \\
\text { typical weather for this time of year where you } \\
\text { currently live? }\end{array}$ \\
\hline \multicolumn{2}{|c|}{ Colder than where I live, Similar to where I live, Hotter than where I live } \\
\hline Thermal sensation & Please describe how you are feeling right now: \\
\hline \multicolumn{2}{|c|}{ Cold, Cool, Slightly Cool, Neutral, Slightly Warm, Warm, Hot } \\
\hline Thermal sensation & Do you find this environment... \\
\hline \multicolumn{2}{|c|}{ Very Uncomfortable, Uncomfortable, Acceptable, Comfortable, Very Comfortable } \\
\hline Risk perception & $\begin{array}{l}\text { A heat wave is a period of unusually and } \\
\text { uncomfortably hot weather. If a heat wave were to } \\
\text { occur here, how much, if at all, do you think it would } \\
\text { harm the following? }\end{array}$ \\
\hline \multicolumn{2}{|c|}{$\begin{array}{l}\text { An X placed on a scale from } 0 \% \text { to } 100 \% \text { for both their health and their community's } \\
\text { health. }\end{array}$} \\
\hline Risk perception & $\begin{array}{l}\text { A heat wave is a period of unusually and } \\
\text { uncomfortably hot weather. If a heat wave were to } \\
\text { occur in your local area (where you live), how much } \\
\text { if at all, do you think it would harm the following? }\end{array}$ \\
\hline \multicolumn{2}{|c|}{$\begin{array}{l}\text { An X placed on a scale from } 0 \% \text { to } 100 \% \text { for both their health and their community's } \\
\text { health. }\end{array}$} \\
\hline Risk Perception & $\begin{array}{l}\text { How worried, if at all, are you about the effects of } \\
\text { heat waves on the following? }\end{array}$ \\
\hline \multicolumn{2}{|c|}{$\begin{array}{l}\text { An X placed on a scale from } 0 \% \text { to } 100 \% \text { for both their health and their community's } \\
\text { health. }\end{array}$} \\
\hline Behavior & Did you check the weather conditions for today? \\
\hline \multicolumn{2}{|l|}{ Yes, No } \\
\hline Behavior & $\begin{array}{l}\text { How many liters of water, per person, is your group } \\
\text { carrying? }\end{array}$ \\
\hline \multicolumn{2}{|c|}{ None, Less than $1 / 2$ liter, $1 / 2$ to 1 liter, $1-2$ liters, $2-3$ liters, More than 3 liters } \\
\hline \multicolumn{2}{|l|}{ Demographics } \\
\hline Age & $\begin{array}{l}18-24 \text { years old, } 25-34 \text { years old, } 35-44 \text { years old } \\
45-54 \text { years old, } 55-64 \text { years old, } 65-74 \text { years old, } 75 \\
\text { years or older }\end{array}$ \\
\hline Gender & $\begin{array}{l}\text { Male, Female, Non-binary or third gender/Prefer to } \\
\text { self-describe }\end{array}$ \\
\hline
\end{tabular}




\begin{tabular}{|l|l|}
\hline Hispanic/Non-Hispanic & Yes, No \\
\hline Race/ethnicity & $\begin{array}{l}\text { African American or Black, Asian, American Indian } \\
\text { or Alaska Native, Native Hawaiian or Pacific } \\
\text { Islander, White or Caucasian, Other }\end{array}$ \\
\hline Education & $\begin{array}{l}\text { Less than high school, Some high school, no } \\
\text { diploma, High school graduate or GED, Some } \\
\text { college, no degree, Associate degree, Bachelor's } \\
\text { degree, Master's, professional or doctorate degree }\end{array}$ \\
\hline $\begin{array}{l}\text { Note. The name of variable in right-column in italics, question in left-column, possible answers } \\
\text { (in gray). }\end{array}$ \\
\hline
\end{tabular}

The Utah State University Institutional Review Board (IRB) approved this survey on May 29, 2018, protocol \#9353. Both the BLM and the NPS approved the survey before surveying began at each site.

\subsection{COLLECTION PROCEDURES}

At the trailheads of each trail, I used a random sampling technique as follows. Since visitation during the week and weekends can vary (peak visitation or not), I surveyed on various days across various time (Table 2). Additionally, I recruited groups to participate at evenly spaced intervals established at the start of each surveying session. The interval varied if the day was a high visitation day or a low visitation day. For example, during most surveying sessions at Corona Arch trailhead I could approach almost all groups, such as every group or every other group. On the other hand, at Delicate Arch trailhead it was clear I would not be able to approach at such a high rate so a larger surveying interval was established. Once the interval was established, it was used until the end of that surveying session (Table 3). The intent of this sampling technique was to maximize participation yet minimize the number of participants surveyed at a given time. When surveying too many groups at once, I ran the risk of becoming disorganized and could unintentionally create 
errors in my sampling on that day. I recorded the time at which I handed out the survey and when it was returned to me, I wrote the time it was handed out on the physical survey. By recording my data immediately after surveying, I was able to correct errors in organization before the data was too far removed to correct. If the designated group declined to participate, I asked the following group to participate, using that group as the designated group and continued the spaced intervals afterwards. I asked only one member of each group to participate. The individual whose birthday was coming up next was selected to randomize within groups. If, however that group member declined to participate, the person who verbally agreed to participate completed the survey. It was

Table 2

Survey timetable

\begin{tabular}{|r|l|r|l|r|r|r|}
\hline Date* & Trail & $\begin{array}{l}\text { Survey } \\
\text { day }\end{array}$ & $\begin{array}{l}\text { Survey } \\
\text { session** }\end{array}$ & $\begin{array}{l}\text { Start } \\
\text { time*** }\end{array}$ & $\begin{array}{l}\text { End } \\
\text { time*** }\end{array}$ & $\begin{array}{l}\text { Total } \\
\text { time**** }\end{array}$ \\
\hline $6 / 7 / 2018$ & Corona & 1 & 1 & $10: 58$ & $12: 49$ & $1: 51$ \\
\hline $6 / 8 / 2018$ & Corona & 2 & 2 & $9: 01$ & $11: 01$ & $2: 00$ \\
\hline $6 / 11 / 2018$ & Corona & 3 & 3 & $17: 04$ & $19: 58$ & $2: 54$ \\
\hline $6 / 12 / 2018$ & Corona & 4 & 4 & $8: 12$ & $10: 58$ & $2: 46$ \\
\hline $6 / 12 / 2018$ & Corona & 4 & 5 & $19: 10$ & $20: 28$ & $1: 18$ \\
\hline $6 / 13 / 2018$ & Corona & 5 & 6 & $13: 15$ & $15: 15$ & $2: 00$ \\
\hline $6 / 15 / 2018$ & Corona & 6 & 7 & $15: 59$ & $19: 00$ & $3: 01$ \\
\hline $6 / 16 / 2018$ & Corona & 7 & 8 & $7: 10$ & $10: 10$ & $3: 00$ \\
\hline $6 / 16 / 2018$ & Corona & 7 & 9 & $12: 40$ & $14: 58$ & $2: 18$ \\
\hline $6 / 17 / 2018$ & Corona & 8 & 10 & $7: 08$ & $9: 04$ & $1: 56$ \\
\hline $6 / 25 / 2018$ & Corona & 9 & 11 & $12: 50$ & $15: 55$ & $3: 05$ \\
\hline $6 / 27 / 2018$ & Corona & 10 & 12 & $17: 15$ & $20: 25$ & $3: 10$ \\
\hline $6 / 28 / 2018$ & Corona & 11 & 13 & $9: 01$ & $11: 55$ & $2: 54$ \\
\hline $6 / 29 / 2018$ & Corona & 12 & 14 & $7: 53$ & $10: 41$ & $2: 48$ \\
\hline $6 / 30 / 2018$ & Corona & 13 & 15 & $17: 10$ & $20: 30$ & $3: 20$ \\
\hline $7 / 1 / 2018$ & Corona & 14 & 16 & $10: 00$ & $13: 00$ & $3: 00$ \\
\hline $7 / 2 / 2018$ & Delicate & 15 & 17 & $8: 00$ & $11: 05$ & $3: 05$ \\
\hline $7 / 3 / 2018$ & Delicate & 16 & 18 & $11: 56$ & $15: 01$ & $3: 05$ \\
\hline $7 / 5 / 2018$ & Delicate & 17 & 19 & $14: 58$ & $18: 00$ & $3: 02$ \\
\hline $7 / 6 / 2018$ & Delicate & 18 & 20 & $10: 01$ & $12: 54$ & $2: 53$ \\
\hline & & & & & & \\
\hline
\end{tabular}




\begin{tabular}{|r|l|r|r|r|r|r|}
\hline $7 / 7 / 2018$ & Delicate & 19 & 21 & $9: 02$ & $11: 10$ & $2: 08$ \\
\hline $7 / 8 / 2018$ & Delicate & 20 & 22 & $17: 15$ & $20: 14$ & $2: 59$ \\
\hline $7 / 9 / 2018$ & Delicate & 21 & 23 & $15: 10$ & $18: 10$ & $3: 00$ \\
\hline $7 / 10 / 2018$ & Delicate & 22 & 24 & $9: 15$ & $12: 00$ & $2: 45$ \\
\hline
\end{tabular}

*Date format: MM/DD/YYYY.

** On two days I conducted two survey sessions.

***I recorded the time that I started and ended surveying. While there was an even target time to start and end, due to traffic on the roads to the site or low hiker turn out, the exact start and end times are not perfect. Time format: $24 \mathrm{HR}$.

*****Target time session was 2 hours while at Corona and 3 hours at Delicate due to the greater travel time it took to get to Delicate Arch trailhead.

Table 3

Surveying rates

\begin{tabular}{|c|c|c|c|c|c|}
\hline Date* & Trail & $\begin{array}{l}\text { Surveying } \\
\text { interval** }\end{array}$ & $\begin{array}{l}\text { Number of } \\
\text { surveys } \\
\text { collected } * * *\end{array}$ & Rejections**** & $\begin{array}{l}\text { Number of } \\
\text { people } \\
\text { approached } * * * * *\end{array}$ \\
\hline $6 / 7 / 2018$ & Corona & $50 \%$ & 7 & 3 & 10 \\
\hline $6 / 8 / 2018$ & Corona & $67 \%$ & 8 & 4 & 12 \\
\hline $6 / 11 / 2018$ & Corona & $50 \%$ & 10 & 0 & 10 \\
\hline $6 / 12 / 2018$ & Corona & $100 \%$ & 17 & 1 & 18 \\
\hline $6 / 12 / 2018$ & Corona & $100 \%$ & 3 & 0 & 3 \\
\hline $6 / 13 / 2018$ & Corona & $100 \%$ & 1 & 0 & 1 \\
\hline $6 / 15 / 2018$ & Corona & $67 \%$ & 7 & 1 & 8 \\
\hline $6 / 16 / 2018$ & Corona & $67 \%$ & 12 & 2 & 14 \\
\hline $6 / 16 / 2018$ & Corona & $67 \%$ & 10 & 2 & 12 \\
\hline $6 / 17 / 2018$ & Corona & $100 \%$ & 9 & 0 & 9 \\
\hline $6 / 25 / 2018$ & Corona & $80 \%$ & 3 & 0 & 3 \\
\hline $6 / 27 / 2018$ & Corona & $50 \%$ & 2 & 0 & 2 \\
\hline $6 / 28 / 2018$ & Corona & $100 \%$ & 9 & 1 & 10 \\
\hline $6 / 29 / 2018$ & Corona & $67 \%$ & 9 & 0 & 9 \\
\hline $6 / 30 / 2018$ & Corona & $80 \%$ & 11 & 2 & 13 \\
\hline $7 / 1 / 2018$ & Corona & $100 \%$ & 16 & 2 & 18 \\
\hline $7 / 2 / 2018$ & Delicate & $14 \%$ & 30 & 5 & 35 \\
\hline $7 / 3 / 2018$ & Delicate & $70 \%$ & 25 & 1 & 26 \\
\hline $7 / 5 / 2018$ & Delicate & $77 \%$ & 23 & 5 & 28 \\
\hline $7 / 6 / 2018$ & Delicate & $50 \%$ & 33 & 4 & 37 \\
\hline $7 / 7 / 2018$ & Delicate & $33 \%$ & 30 & 10 & 40 \\
\hline $7 / 8 / 2018$ & Delicate & $67 \%$ & 30 & 2 & 32 \\
\hline $7 / 9 / 2018$ & Delicate & $60 \%$ & 23 & 1 & 24 \\
\hline
\end{tabular}




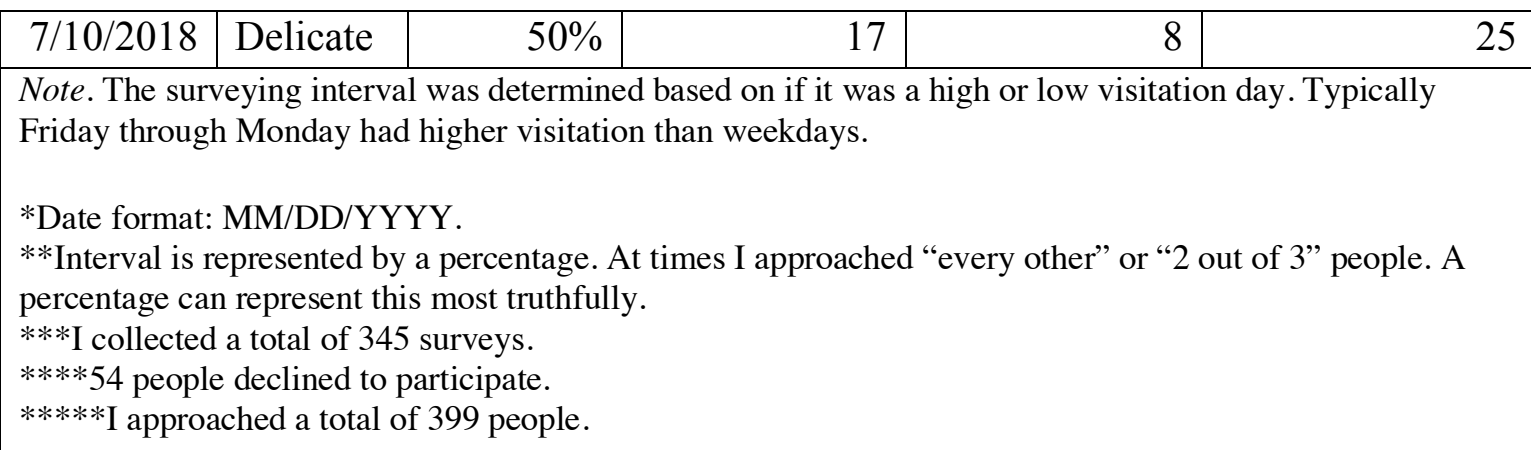

especially apparent that in order for families to participate, the parent most willing to would need to be the one to complete the survey. As an incentive, participants were offered a travel size tube of sunscreen for completing the survey. This incentive proved to be effective.

The most common reason hikers declined to participate was due to English language comprehension. Hikers would signal that they could not understand me and politely decline. The second most common reason hikers declined was due to the heat. One hiker declined by stating "No, it's getting hotter by the minute." Other hikers would express an already exhausted look and then politely decline. Only once was a rejection due to perceived stress. Parents with three kids debated if they should hike due to the heat before declining to participate.

There are many tour buses that enter Arches NP, and in order to hike to Delicate Arch tour buses need a specialized permit. I did not approach any visitors from tour buses for participation as it would be difficult to distribute one survey to the group and then have the group wait on that one participant. Additionally, many of the tour buses cater to nonEnglish speakers, which as previously noted was the primary reason for rejection. Tour bus visitors tend to be from East Asian countries. Thus, while many visitors from East Asian countries visit the park, they are likely to be underrepresented in this survey. 
Once I started surveying at Delicate Arch trailhead, I coordinated with the ranger that monitors the trailhead so that their conversations with visitors would not affect participation or responses. On a day when I was there, the ranger would stand 20-30 feet onto the trail near the warning sign (Fig. 3 in Appendix B) and speak to people after they had taken the survey. In this way, they were able to allow me to conduct surveys and do their job of warning visitors about the risks associated with the hike.

While collecting survey responses, I also recorded atmospheric conditions using a Kestrel 5400 Heat Stress Tracker instrument. To ensure that the data would be collected consistently the Kestrel was placed on a tripod 1.3 meters off the ground. This height was chosen as it is the standard used in similar studies (Johansson et al., 2014; Lam et al., 2016). The instrument recorded data every minute. At the end of each survey period, the data was downloaded and saved. Data collected from the instrument includes: air temperature, relative humidity, wind speed and direction (true and magnitude), crosswind, heat stress index, wet bulb temperature, thermal work limit (TWL) psychrometric wet bulb temperature, natural wet bulb temperature, globe temperature, wind chill, headwind, barometric pressure, and dew point. The instrumental weather data was compared to participants' temperature estimates based on their time of response. As a backup should data for a specific time not be recorded, a SensorPush temperature and humidity sensor was also used at the same location, recording at minute intervals. However, the Kestrel successfully collected temperature data for the all the times necessary.

Surveys were collected on 22 days over the course of 34 days. The survey interval was designed to balance the number of times surveys were conducted across high and low visitation days and times. The time of day was recorded at the time of the participation (just 
after the survey was handed to the participant). The target sample was a total of 450 participants. This target was based on previous thermal perception field studies, which surveyed an average of 437 people over the course of 3 weeks to 10 months (Lai et al., 2014; Lam et al., 2016; Lin, 2009; Ng \& Cheng, 2012; Rutty \& Scott, 2015; Yin et al., 2012). In total I collected 345 surveys. I approached 399 groups and was rejected a total of 54 times. The participation rate for the entire survey period was $86 \%$.

All survey responses were entered in a csv file using Microsoft Excel. If participants had left questions blank, a value of -9999 was entered. After loading the file into R Studio, the data was cleaned and values of -9999 were assigned an NA value. Some variables were calculated after all surveys were entered. Participants' overall risk perception was calculated by summing the values from all six of the risk perception questions then dividing it by 6 to give each participant a risk perception value on a scale of $0-100$. This variable is labeled 'riskp.' Cronbach's $\alpha$ indicated that the sum of these six items into a scale was reliable $(\alpha=0.86)$. A temperature 'difference' value was calculated as the absolute difference between the temperature participants estimated the temperature to be and the actual temperature taken at the time of their respective survey. Thermal sensation variables however were analyzed as individual variables. Participants' location was used to assign a region or division based on the U.S. Census Bureau classifications (U. S. Census Bureau, 2018b). This region-based assignment was additionally used to give participants a geographic 'distance' variable. In this case, the classification used was the distance from Moab. Participants were assigned one of the following groups: Utah, West, U.S. and Non-US. Participants' location was also used to assign a Köppen Climate Classification. 


\subsection{ANALYSIS}

The variables thermal perception, difference, and riskp, were analyzed separately as dependent variables through linear mixed-effects regression models in $\mathrm{R}$ using the 'Ime4' (Bates, Mächler, Bolker, \& Walker, 2015), and 'sjPlot' packages (Lüdecke \& Schwemmer, 2018). Demographic features were added to the model first as fixed-effects. After controlling for demographic features, models were built iteratively by adding one random effect at a time.

The variables check (Q8), and water (Q18) were also analyzed separately as dependent variables through a generalized linear mixed-effects models using the same packages as the previous models (Bates et al., 2015; Lüdecke \& Schwemmer, 2018). Demographic features were added first as fixed effects, then the models were built upon iteratively by adding one random effect at a time. Since the responses for water in liters per person (Q18) were not dichotomous, the variable was split into two new dichotomous responses. One version of the new variable split the variable at the 1-liter mark, where responses of less than 1 liter were coded as 0 , and responses of more than 1 liter were coded as 1 . The other version of the new variable split the variable at the 2-liter mark, responses of less than 2 liters were coded as 1 , responses of more than 2 liters were coded as 2 . This allowed the two different models to compare when participants were likely to carry less or more than 1 liter of water, or carry less or more than 2 liters of water. The 2-liter mark was used because the National Park Service recommends carrying 2 or more liters of water per person on the Delicate Arch hike.

For the instrumental records variables it was important to not use variables that correlate together. For this reason the variables of temperature, dew point, and globe 
temperature were used. Temperature is measured in degrees Celsius. Dew point is the temperature in degrees Celsius below which water can begin to condense. Globe temperature, also in degrees Celsius, is the temperature measured inside a 6-inch copper globe painted black. Globe temperature is also known as "black globe temperature" and is intended to resemble the thermal conditions felt by the human body. While globe temperature can correlate with temperature, it does not correlate with dew point. These variables were first used in the models separately, then together to see which variable, if any, had a more significant impact on the dependent variable of the respective model.

\section{RESULTS}

\subsection{DESCRIPTIVE}

From the three thermal sensation questions, most participants reported that they found the environment to be 'hotter than where they live,' $(n=206)$, reported feeling 'warm,' $(n=111)$ and that they found the environment to be 'acceptable' $(n=178)$. On average, the temperature when surveying people was $33.7^{\circ} \mathrm{C}\left(92.6^{\circ} \mathrm{F}\right)\left(\sigma=4^{\circ} \mathrm{C}\right)$. Yet, the average temperature estimate from participants was $33^{\circ} \mathrm{C}\left(91.6^{\circ} \mathrm{F}\right)\left(\sigma=5^{\circ} \mathrm{C}\right)[\mathrm{Q} 9]$. The average risk perception score of participants was 44/100 (riskp) $(\sigma=19)$ [Q13-Q15]. However, participants reported the highest average risk perception on Q13 (If a heat wave were to occur in your local area (where you live), how much, if at all, do you think it would harm your community?) at 56/100 $(\sigma=22)$. Across the six risk perception questions, respondents reported higher risk perceptions for their community's health than for their own health. Most participants checked the weather $(n=295)$. The most frequently reported 
amount of water carried was 1-2 liters. This is just under the recommended amount of water by the National Park Service.

Table 4

Descriptive statistics for dependent variables

\begin{tabular}{|c|c|c|}
\hline \multicolumn{3}{|c|}{ Frequency of Behavioral Variables } \\
\hline & $\mathrm{N}$ & $\%$ \\
\hline \multicolumn{3}{|l|}{ Check the weather } \\
\hline No & 47 & 13.7 \\
\hline Yes & 295 & 85.8 \\
\hline No Response & 2 & 0.6 \\
\hline \multicolumn{3}{|c|}{ Carrying water (amount per person) } \\
\hline None & 3 & 0.9 \\
\hline Less than $1 / 2$ liter & 9 & 2.6 \\
\hline $1 / 2-1$ liter & 74 & 21.5 \\
\hline $1-2$ liters & 154 & 44.8 \\
\hline 2-3 liters & 72 & 20.9 \\
\hline More than 3 liters & 32 & 9.3 \\
\hline No Response & 0 & 0 \\
\hline
\end{tabular}

The distribution of respondents across most demographic characteristics differs in several key ways from the demographics of the US according to the 2017 American Community Survey (Table 5). However, this survey includes international participants, which means it cannot be perfectly compared. As compared to the 2017 American Community Survey most age groups were overrepresented in the sample, except for ' 55 64 years' and ' $65+$ years' which were underrepresented by 4.2 and 12.9 percentage points respectively. By gender, males were overrepresented by 7.8 percentage points. The 2017 American Community Survey does not include a non-binary or third gender option, while this survey provided that as a response option. Non-Hispanics were overrepresented by 10.2 percentage points. By race, 'African American or Black' respondents were 
underrepresented by 11.8 percentage points, 'Asian' respondents were overrepresented by 3.9 percentage points, and 'White or Caucasian' respondents were overrepresented by 9 percentage points. By education, attainment below a Bachelor's degree, less than high school, some high school, high school graduate, some collage, associate decree, was underrepresented by $4.2,6.6,22.4,6.8,1.9$ percentage points respectively. However, this sample overrepresents 'Bachelor's degree' and 'Master's, professional, or doctorate degree' by 19.6 and 22.5 percentage points respectively.

Table 5

Descriptive statistics for random effects

\begin{tabular}{|lccc|}
\hline Frequency of Demographic Variables & \multicolumn{3}{l|}{} \\
\hline \hline Age & N & $\%$ & National \%* \\
\hline 18-24 years & 50 & 14.5 & 7.0 \\
25-34 years & 109 & 31.7 & 13.0 \\
35-44 years & 69 & 20.1 & 12.7 \\
45-54 years & 72 & 20.9 & 13.4 \\
55-64 years & 36 & 10.5 & 14.7 \\
65+ years & 7 & 2.0 & 14.9 \\
No Response & 1 & 0.3 & - \\
\hline Gender & & & \\
\hline Male & 196 & 57.0 & 49.2 \\
Female & 145 & 42.2 & 50.8 \\
Non-binary or third gender & 1 & 0.3 & - \\
No Response & 2 & 0.6 & - \\
\hline Hispanic & & & \\
\hline No & 317 & 92.2 & 82.4 \\
Yes & 25 & 7.3 & 17.6 \\
No Response & 2 & 0.6 & - \\
\hline Race & & & \\
\hline African American or Black & 3 & 0.9 & 12.7 \\
Asian & 32 & 9.3 & 5.4 \\
Native Hawaiian or Pacific Islander & 1 & 0.3 & 0.2 \\
White or Caucasian & 282 & 82.0 & 73.0 \\
& & &
\end{tabular}




\begin{tabular}{|lccc|} 
Other & 19 & 5.5 & 8.7 \\
No Response & 7 & 2.0 & - \\
\hline Education & 4 & & \\
\hline Less than high school & 4 & 0.6 & 5.4 \\
Some high school, no diploma & 17 & 4.9 & 7.2 \\
High school graduate - diploma or GED & 48 & 14.0 & 27.3 \\
Some college, no degree & 22 & 6.4 & 8.3 \\
Associate degree & 133 & 38.7 & 19.1 \\
Bachelor's degree & 118 & 34.3 & 11.8 \\
Master's, professional, or doctorate degree & 0 & 0 & - \\
No Response & *American Community Survey 2017 (U. S. Census Bureau, 2017) \\
\hline \multicolumn{4}{l}{} \\
\hline
\end{tabular}

The distribution of respondents across geographic characteristics is overrepresentative of the Western region according to 2018 population estimates from the U.S. Census Bureau (Table 6). The Midwest is overrepresented by only 0.6 percentage points, the Northeast is underrepresented by 11.3 , the South is underrepresented by 18.3 , and the West is overrepresented by 18.4. Considering the location of the study area is in the western region of the United States, this overrepresentation of western states is not surprising.

The distribution of respondents across the Köppen Climate Classifications is uneven (Table 6). The 'Arid' classification does not appear to be overrepresented even though the study area is in an arid region of the United States. More than half of the respondents (53.8\%) are from a 'temperate' climate. 'Tropical' climates were the least represented at $1.5 \%$ of the respondents.

Table 6

Descriptive statistics for fixed effects

\begin{tabular}{|c|c|c|c|}
\hline \multicolumn{4}{|c|}{ Frequency of Geographic Variables } \\
\hline & $\mathrm{N}$ & $\%$ & National \%* \\
\hline \multicolumn{4}{|l|}{ Region 4} \\
\hline Midwest & 57 & 16.6 & 17.2 \\
\hline
\end{tabular}




\begin{tabular}{|lccc|} 
Northeast & 33 & 9.6 & 20.9 \\
South & 68 & 19.8 & 38.1 \\
West & 145 & 42.2 & 23.8 \\
Non US & 41 & 11.9 & - \\
\hline Geographic 'distance' & & & \\
\hline Utah & 46 & 13.3 & - \\
West & 99 & 28.8 & - \\
US & 158 & 45.9 & - \\
Non US & 41 & 11.9 & - \\
\hline Köppen & & & \\
\hline Arid & 44 & 12.8 & - \\
Continental & 110 & 32.0 & - \\
Temperate & 185 & 53.8 & - \\
Tropical & 5 & 1.5 & - \\
\hline *Population Estimates 2018 (U. S. Census Bureau, 2018a) \\
\hline
\end{tabular}

This survey was conducted at two trailheads and as such, there are minor differences between the average risk perceptions. At Corona Arch trailhead the average risk perception of participants was $42 / 100$ (riskp) $(\sigma=20)$. At Delicate Arch trailhead the average risk perception of participants was $46 / 100$ (riskp) $(\sigma=19)$. This demonstrates that while Corona hikers had lower heat risk perceptions overall, there is a larger variation across participants.

\subsection{EXPLORATORY REGRESSIONS}

In order to identify which variables were most associated with the dependent variables of thermal perception and risk perception, a series of linear regressions were performed using one variable at a time. For the dependent variable of thermal perception, thermal sensations had a small association. Thermal comparison (e.g. "how does this environment compare to where you currently live" [Q10]), explained the smallest amount of variation with an adjusted $\mathrm{r}^{2}$ of $5 \%$. Environment as a thermal sensation ("how do you 
find this environment" [Q12]), explained only 9\% of the variation (adjusted $\mathrm{r}^{2}$ ). Thermal sensation (e.g. "how do you feel..." [Q11]), explained the largest amount of variation with an adjusted $\mathrm{r}^{2}$ of $14 \%$. Instrumental records were able to explain more of the variation in the linear regression models predicting thermal perceptions. The three instrumental records of temperature, dew point, and globe temperature were each able to explain $62 \%$ of the variation. Combined they were able to explain $64 \%$ of the variation. Thus, instrumental records were better than thermal sensations in predicting thermal perceptions.

Similarly, a series of linear regressions were performed to identify how a series of predictor variables were associated with heat risk perception. In these tests all of the variables were able to explain no more than $1 \%$ of the variation in risk perception. This demonstrates that none of the variables have a strong impact on risk perception scores.

\subsection{LINEAR MIXED-EFFECT MODELS}

Results from the linear mixed-effects model predicting participants thermal perception, or temperature estimates $(\mathrm{Q} 9)$, shows that an increase of $1^{\circ} \mathrm{C}$ would result in a $0.76^{\circ} \mathrm{C}$ increase in perceived temperature (Table 7). The environmental variables (temperature (C), dew point (C), and globe temperature (C)) had the largest and only significant effect on thermal perception; temperature had the largest effect. The effects of all three variables (temperature, dew point, and globe temperature) were positive; as these variables increased, so too did the perceived temperature as reported by participants. Spatial and demographic variables had little influence in this model.

The model predicting the absolute difference between a participant's estimated temperature and the actual temperature (Table 8), shows that neither temperature variables, spatial variables, nor demographic variables have a significant impact on a participants' 
temperature estimate. This null result is important since temperature is not an influential factor in how accurate a participant's temperature estimate was. From both model sets, the AIC increases as the complexity of the model increases. Thus, in predicting temperature estimates and temperature estimate accuracy, simpler models perform better.

Lastly in the linear mixed-effect set of models, none of the variables strongly predicted risk perception (riskp) (Table 9). However, again the null results of this model are relevant since temperature is not an influential factor in predicting a participant's risk perception.

\subsection{GENERALIZED LINEAR MIXED-EFFECTS MODELS}

Results from the generalized linear mixed-effects model predicting if participants checked the weather show that risk perception was a strong predictor of checking the weather, while temperature was not (Table 10). The AICs from this set of models continued to increase until risk perception was added to the model, then it decreased. This model shows that a 1-unit increase in total risk perception increases the likelihood that the participant checked the weather by $2 \%$. Similarly, a 10 -unit increase in risk perception, increases the likelihood that the participant checked the weather by $20 \%$. Demographic random effects exhibited very little variation in predicting checking the weather. Age appears to be the strongest individual predictor, however all of the predictors had essentially no influence. Odd ratios for the random effects of this model are found in Appendix F.

However, risk perception was not a strong predictor of whether or not participants carried any amount of water (Table 11). None of the variables strongly influenced the likelihood that the participant was carrying the specified amount of water. Utahns were the 
least likely to carry water more than 1 liter of water compared to the other the geographic ‘distance' groups (West, US, and non US) (Table 11). 
Table 7

\section{Thermal perception}

Thermal Perception (temperature estimate)

$\begin{array}{lllll}\text { Model } 1 & \text { Model } 2 & \text { Model } 3 & \text { Model } 4 & \text { Model } 5\end{array}$

Predictors Estimates Conf. Int Estimates Conf. Int Estimates Conf. Int Estimates Conf. Int Estimates Conf. In

\begin{tabular}{|c|c|c|c|c|c|c|c|c|c|c|}
\hline Intercept & 2.38 & $\begin{array}{c}-0.50- \\
5.25\end{array}$ & 2.51 & $\begin{array}{c}-0.54- \\
5.56\end{array}$ & 3.11 & $\begin{array}{c}-0.24- \\
6.45\end{array}$ & 2.58 & $\begin{array}{c}-0.56- \\
5.71\end{array}$ & 3.19 & $\begin{array}{c}-0.26- \\
6.63\end{array}$ \\
\hline $\begin{array}{l}\text { Temperature } \\
\text { (C) }\end{array}$ & $\begin{array}{l}0.76 \\
* * *\end{array}$ & $\begin{array}{c}0.65- \\
0.88\end{array}$ & $\begin{array}{l}0.77 \\
* * *\end{array}$ & $\begin{array}{c}0.66- \\
0.88\end{array}$ & $\begin{array}{l}0.76 \\
* * *\end{array}$ & $\begin{array}{c}0.65- \\
0.87\end{array}$ & $\begin{array}{l}0.76 \\
* * *\end{array}$ & $\begin{array}{c}0.64- \\
0.87\end{array}$ & $\begin{array}{l}0.75 \\
* * *\end{array}$ & $\begin{array}{c}0.64- \\
0.87\end{array}$ \\
\hline $\begin{array}{l}\text { Dew Point } \\
\text { (C) }\end{array}$ & $0.07^{*}$ & $\begin{array}{c}0.01- \\
0.12\end{array}$ & $0.07^{*}$ & $\begin{array}{c}0.02- \\
0.13\end{array}$ & $0.08^{* *}$ & $\begin{array}{c}0.02- \\
0.13\end{array}$ & $0.07^{*}$ & $\begin{array}{c}0.02- \\
0.13\end{array}$ & $0.08^{* *}$ & $\begin{array}{c}0.02- \\
0.13\end{array}$ \\
\hline $\begin{array}{l}\text { Globe Temp } \\
\text { (C) }\end{array}$ & $0.11^{* *}$ & $\begin{array}{c}0.04- \\
0.18\end{array}$ & $0.11^{* *}$ & $\begin{array}{c}0.04- \\
0.19\end{array}$ & $0.12^{* *}$ & $\begin{array}{c}0.05- \\
0.19\end{array}$ & $0.12^{* *}$ & $\begin{array}{c}0.04- \\
0.19\end{array}$ & $0.12^{* *}$ & $\begin{array}{c}0.05- \\
0.20\end{array}$ \\
\hline $\begin{array}{l}\text { United } \\
\text { States (a) }\end{array}$ & & & & & -0.08 & $\begin{array}{c}-1.15- \\
0.99\end{array}$ & & & -0.06 & $\begin{array}{l}-1.14- \\
1.02\end{array}$ \\
\hline Utah (a) & & & & & -0.82 & $\begin{array}{c}-2.14- \\
0.50\end{array}$ & & & -0.71 & $\begin{array}{c}-2.12- \\
0.69\end{array}$ \\
\hline $\begin{array}{l}\text { Western } \\
\text { States (a) }\end{array}$ & & & & & -0.63 & $\begin{array}{c}-1.77- \\
0.52\end{array}$ & & & -0.61 & $\begin{array}{c}-1.83- \\
0.60\end{array}$ \\
\hline $\begin{array}{l}\text { Continental } \\
\text { (b) }\end{array}$ & & & & & & & 0.15 & $\begin{array}{c}-0.94- \\
1.25\end{array}$ & -0.14 & $\begin{array}{c}-1.37- \\
1.10\end{array}$ \\
\hline $\begin{array}{l}\text { Temperate } \\
\text { (b) }\end{array}$ & & & & & & & 0.41 & $\begin{array}{c}-0.63- \\
1.46\end{array}$ & 0.04 & $\begin{array}{l}-1.12- \\
1.20\end{array}$ \\
\hline Tropical (b) & & & & & & & 1.36 & $\begin{array}{c}-1.54- \\
4.26\end{array}$ & 0.84 & $\begin{array}{c}-2.14- \\
3.83\end{array}$ \\
\hline \multicolumn{11}{|c|}{ Random Effects } \\
\hline$\sigma^{2}$ & 9.64 & & 9.46 & & 9.43 & & 9.49 & & 9.50 & \\
\hline \multirow[t]{6}{*}{$\tau_{00}$} & \multirow[t]{6}{*}{0.21 Trail } & & \multicolumn{2}{|c|}{0.11 Q20_age } & \multicolumn{2}{|c|}{0.15 Q20_age } & \multicolumn{2}{|c|}{0.13 Q20_age } & \multicolumn{2}{|c|}{0.16 Q20_age } \\
\hline & & & \multicolumn{2}{|c|}{0.00 Q24_educ_bin } & \multicolumn{2}{|c|}{0.00 Q24_educ_bin } & \multicolumn{2}{|c|}{0.00 Q24_educ_bin } & \multicolumn{2}{|c|}{0.00 Q24_educ_bin } \\
\hline & & & \multicolumn{2}{|c|}{0.05 Q21_gender } & \multicolumn{2}{|c|}{0.06 Q21_gender } & \multicolumn{2}{|c|}{0.07 Q21_gender } & \multicolumn{2}{|c|}{0.07 Q21_gender } \\
\hline & & & \multicolumn{2}{|c|}{0.00 Q23_race_bin } & \multicolumn{2}{|c|}{0.00 Q23_race_bin } & \multicolumn{2}{|c|}{0.00 Q23_race_bin } & \multicolumn{2}{|c|}{0.00 Q23_race_bin } \\
\hline & & & \multicolumn{2}{|c|}{0.64 Q22_hispanic } & \multicolumn{2}{|c|}{1.04 Q22_hispanic } & \multicolumn{2}{|c|}{0.70 Q22_hispanic } & \multicolumn{2}{|c|}{0.91 Q22_hispanic } \\
\hline & & & \multicolumn{2}{|c|}{0.16 Trail } & \multicolumn{2}{|c|}{0.10 Trail } & \multicolumn{2}{|c|}{0.16 Trail } & \multicolumn{2}{|c|}{0.10 Trail } \\
\hline Observations & 342 & & \multicolumn{2}{|l|}{342} & \multicolumn{2}{|l|}{342} & \multicolumn{2}{|l|}{342} & \multicolumn{2}{|l|}{342} \\
\hline AIC & \multicolumn{2}{|l|}{1771.474} & \multicolumn{2}{|c|}{1779.418} & 1781.09 & & 1781.12 & & 1783.25 & \\
\hline
\end{tabular}

Note. Linear mixed-effect model of thermal perception. (a) Geographic distance, intercept is 'Non US.' (b) Köppen Climate Classification, intercept is 'Arid.' 
Table 8

Thermal difference (difference between perceived and actual air temperature)

Thermal Difference (absolute difference between temperature and temperature estimates)

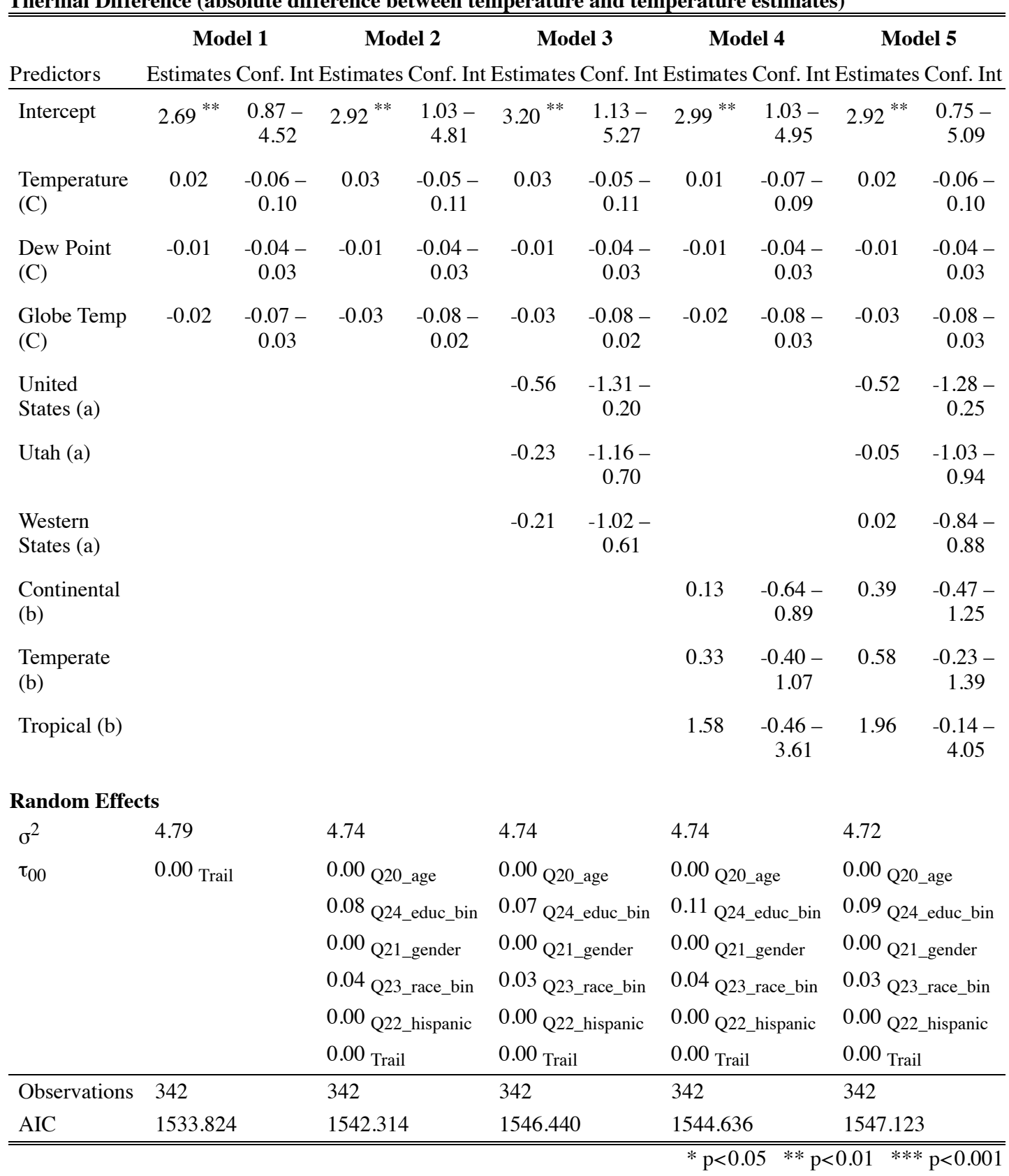

Note. Linear mixed-effect model of the absolute difference between actual temperature and thermal perception. (a) Geographic distance, intercept is 'Non US.' (b) Köppen Climate Classification, intercept is 'Arid.' 
Table 9

\section{Risk perception}

Risk Perception

\begin{tabular}{|c|c|c|c|c|c|c|c|c|}
\hline \multirow[b]{2}{*}{ Predictors } & \multicolumn{2}{|c|}{ Model 1} & \multicolumn{2}{|c|}{ Model 2} & \multicolumn{2}{|c|}{ Model 3} & \multicolumn{2}{|c|}{ Model 4} \\
\hline & Estimates & Conf. Int & Estimates & Conf. Int & Estimates & Conf. Int & Estimates & Conf. Int \\
\hline Intercept & $\begin{array}{l}46.73 \\
* * *\end{array}$ & $\begin{array}{c}39.10- \\
54.35\end{array}$ & $\begin{array}{l}46.93 \\
* * *\end{array}$ & $\begin{array}{c}38.19- \\
55.68\end{array}$ & $\begin{array}{c}54.95 \\
* * *\end{array}$ & $\begin{array}{c}34.21- \\
75.68\end{array}$ & $\begin{array}{c}55.67 \\
* * *\end{array}$ & $\begin{array}{c}34.69- \\
76.64\end{array}$ \\
\hline United States (a) & & & -2.41 & $\begin{array}{c}-9.22- \\
4.40\end{array}$ & -2.56 & $\begin{array}{c}-9.41- \\
4.29\end{array}$ & -2.59 & $\begin{array}{c}-9.45- \\
4.27\end{array}$ \\
\hline Utah (a) & & & 2.54 & $\begin{array}{c}-5.90- \\
10.97\end{array}$ & 2.45 & $\begin{array}{c}-6.08- \\
10.97\end{array}$ & 2.32 & $\begin{array}{c}-6.22- \\
10.87\end{array}$ \\
\hline Western States (a) & & & 0.47 & $\begin{array}{c}-6.76- \\
7.71\end{array}$ & 0.10 & $\begin{array}{c}-7.22- \\
7.42\end{array}$ & -0.01 & $\begin{array}{c}-7.35- \\
7.34\end{array}$ \\
\hline Temperature (C) & & & & & -0.23 & $\begin{array}{c}-0.76- \\
0.29\end{array}$ & -0.26 & $\begin{array}{c}-0.79- \\
0.27\end{array}$ \\
\hline $\begin{array}{l}\text { Temperature Difference } \\
\text { (absolute) }\end{array}$ & & & & & & & -0.16 & $\begin{array}{c}-0.84- \\
0.52\end{array}$ \\
\hline \multicolumn{9}{|l|}{ Random Effects } \\
\hline$\sigma^{2}$ & 370.72 & & 366.88 & & 369.78 & & 370.85 & \\
\hline \multirow[t]{6}{*}{$\tau_{00}$} & \multicolumn{2}{|c|}{1.23 Q20_age } & \multicolumn{2}{|c|}{1.87 Q20_age } & \multicolumn{2}{|c|}{2.62 Q20_age } & \multicolumn{2}{|c|}{2.20 Q20_age } \\
\hline & \multicolumn{2}{|c|}{0.00 Q24_educ_bin } & \multicolumn{2}{|c|}{0.00 Q24_educ_bin } & \multicolumn{2}{|c|}{0.00 Q24_educ_bin } & \multicolumn{2}{|c|}{0.00 Q24_educ_bin } \\
\hline & \multicolumn{2}{|c|}{0.00 Q21_gender } & \multicolumn{2}{|c|}{0.00 Q21_gender } & \multicolumn{2}{|c|}{0.00 Q21_gender } & \multicolumn{2}{|c|}{0.00 Q21_gender } \\
\hline & \multicolumn{2}{|c|}{25.53 Q23_race_bin } & \multicolumn{2}{|c|}{14.86 Q23_race_bin } & \multicolumn{2}{|c|}{24.49 Q23_race_bin } & \multicolumn{2}{|c|}{$\begin{array}{l}24.30 \\
\text { Q23_race_bin }\end{array}$} \\
\hline & \multicolumn{2}{|l|}{3.91 Trail } & \multicolumn{2}{|l|}{4.10 Trail } & \multicolumn{2}{|c|}{10.01 Trail } & \multicolumn{2}{|c|}{10.99 Trail } \\
\hline & \multicolumn{2}{|c|}{$0.00 \mathrm{Q} 22$ hispanic } & \multicolumn{2}{|c|}{0.00 Q22_hispanic } & \multicolumn{2}{|c|}{0.00 Q22_hispanic } & \multicolumn{2}{|c|}{0.00 Q22_hispanic } \\
\hline Observations & \multicolumn{2}{|l|}{328} & \multicolumn{2}{|l|}{328} & \multicolumn{2}{|l|}{328} & \multicolumn{2}{|l|}{328} \\
\hline AIC & \multicolumn{2}{|l|}{2888.227} & 2895.868 & & 2881.476 & & 2883.54 & \\
\hline
\end{tabular}

Note. Linear mixed-effect model of risk perception. (a) Geographic distance, intercept is 'Non US.' 
Table 10

Check the weather

Check the weather

\begin{tabular}{|c|c|c|c|c|c|c|c|c|c|c|}
\hline \multirow[b]{2}{*}{ Predictors } & \multicolumn{2}{|c|}{ Model 1} & \multicolumn{2}{|c|}{ Model 2} & \multicolumn{2}{|c|}{ Model 3} & \multicolumn{2}{|c|}{ Model 4} & \multicolumn{2}{|c|}{ Model 5} \\
\hline & $\begin{array}{l}\text { Odds } \\
\text { Ratios }\end{array}$ & Conf. Int & $\begin{array}{l}\text { Odds } \\
\text { Ratios }\end{array}$ & Conf. Int & $\begin{array}{l}\text { Odds } \\
\text { Ratios }\end{array}$ & Conf. Int & $\begin{array}{l}\text { Odds } \\
\text { Ratios }\end{array}$ & Conf. Int & $\begin{array}{l}\text { Odds } \\
\text { Ratios }\end{array}$ & Conf. Int \\
\hline Intercept & $\begin{array}{l}6.76 \\
* * *\end{array}$ & $\begin{array}{r}2.81- \\
16.25\end{array}$ & $\begin{array}{c}7.36 \\
* *\end{array}$ & $\begin{array}{l}2.16- \\
25.02\end{array}$ & 7.30 & $\begin{array}{l}0.41- \\
129.84\end{array}$ & 7.74 & $\begin{array}{l}0.42- \\
141.04\end{array}$ & 2.53 & $\begin{array}{r}0.11- \\
59.04\end{array}$ \\
\hline United States (a) & & & 0.86 & $\begin{array}{c}0.30- \\
2.50\end{array}$ & 0.86 & $\begin{array}{c}0.30- \\
2.50\end{array}$ & 0.85 & $\begin{array}{c}0.29- \\
2.48\end{array}$ & 0.89 & $\begin{array}{c}0.30- \\
2.61\end{array}$ \\
\hline Utah (a) & & & 0.71 & $\begin{array}{c}0.21- \\
2.45\end{array}$ & 0.71 & $\begin{array}{c}0.21- \\
2.47\end{array}$ & 0.71 & $\begin{array}{c}0.21- \\
2.48\end{array}$ & 0.73 & $\begin{array}{c}0.21- \\
2.58\end{array}$ \\
\hline Western States (a) & & & 1.16 & $\begin{array}{c}0.36- \\
3.72\end{array}$ & 1.16 & $\begin{array}{c}0.36- \\
3.74\end{array}$ & 1.16 & $\begin{array}{c}0.36- \\
3.73\end{array}$ & 1.20 & $\begin{array}{c}0.37- \\
3.87\end{array}$ \\
\hline Temperature (C) & & & & & 1.00 & $\begin{array}{c}0.93- \\
1.08\end{array}$ & 1.00 & $\begin{array}{c}0.93- \\
1.08\end{array}$ & 1.01 & $\begin{array}{c}0.93- \\
1.09\end{array}$ \\
\hline $\begin{array}{l}\text { Temperature } \\
\text { Difference } \\
\text { (absolute) }\end{array}$ & & & & & & & 0.98 & $\begin{array}{c}0.84- \\
1.13\end{array}$ & 0.96 & $\begin{array}{c}0.82- \\
1.11\end{array}$ \\
\hline Risk Perception & & & & & & & & & $\begin{array}{c}1.02 \\
*\end{array}$ & $\begin{array}{c}1.00- \\
1.04\end{array}$ \\
\hline \multicolumn{11}{|l|}{ Random Effects } \\
\hline$\sigma^{2}$ & 3.29 & & 3.29 & & 3.29 & & 3.29 & & 3.29 & \\
\hline \multirow[t]{6}{*}{$\tau_{00}$} & \multicolumn{2}{|c|}{0.16 Q20_age } & \multicolumn{2}{|c|}{0.16 Q20_age } & \multicolumn{2}{|c|}{0.16 Q20_age } & \multicolumn{2}{|c|}{0.16 Q20_age } & \multicolumn{2}{|c|}{0.16 Q20_age } \\
\hline & \multicolumn{2}{|c|}{$\begin{array}{l}0.15 \\
\text { Q24_educ_bin }\end{array}$} & \multicolumn{2}{|c|}{$\begin{array}{l}0.13 \\
\text { Q24_educ_bin }\end{array}$} & \multicolumn{2}{|c|}{$\begin{array}{l}0.13 \\
\text { Q24_educ_bin }\end{array}$} & \multicolumn{2}{|c|}{$\begin{array}{l}0.13 \\
\text { Q24_educ_bin }\end{array}$} & \multicolumn{2}{|c|}{$\begin{array}{l}0.16 \\
\text { Q24_educ_bin }\end{array}$} \\
\hline & \multicolumn{2}{|c|}{$\begin{array}{l}0.14 \\
\text { Q21_gender }\end{array}$} & \multicolumn{2}{|c|}{$\begin{array}{l}0.12 \\
\text { Q21_gender }\end{array}$} & \multicolumn{2}{|c|}{0.12 Q21_gender } & \multicolumn{2}{|c|}{0.12 Q21_gender } & \multicolumn{2}{|c|}{0.18 Q21_gender } \\
\hline & \multicolumn{2}{|c|}{$\begin{array}{l}0.00 \\
\text { Q23_race_bin }\end{array}$} & \multicolumn{2}{|c|}{$\begin{array}{l}0.00 \\
\text { Q23_race_bin }\end{array}$} & \multicolumn{2}{|c|}{$\begin{array}{l}0.00 \\
\text { Q23_race_bin }\end{array}$} & \multicolumn{2}{|c|}{0.00} & \multicolumn{2}{|c|}{0.09} \\
\hline & \multicolumn{2}{|c|}{0.00 Trail } & \multicolumn{2}{|c|}{0.00 Trail } & \multicolumn{2}{|c|}{0.00 Trail } & \multicolumn{2}{|c|}{0.00 Trail } & \multicolumn{2}{|c|}{0.00 Trail } \\
\hline & \multicolumn{2}{|c|}{$\begin{array}{l}0.00 \\
\text { Q22_hispanic }\end{array}$} & $\begin{array}{l}0.00 \\
\text { Q22_his }\end{array}$ & spanic & $\begin{array}{l}0.00 \\
\text { Q22_his }\end{array}$ & panic & $\begin{array}{l}0.00 \\
\text { Q22_his! }\end{array}$ & panic & $\begin{array}{l}0.00 \\
\text { Q22_his }\end{array}$ & spanic \\
\hline Observations & 327 & & 327 & & 327 & & 327 & & 327 & \\
\hline AIC & 269.22 & & 274.26 & & 276.26 & & 278.162 & & 274.53 & \\
\hline
\end{tabular}

Note. Generalized linear mixed-effect model of checking the weather. (a) Geographic distance, intercept is 'Non US.' 
Table 11

Carrying more than 1 liter of water

Carrying water (more than 1 liter)

\begin{tabular}{|c|c|c|c|c|c|c|c|c|c|c|}
\hline \multirow[b]{2}{*}{ Predictors } & \multicolumn{2}{|c|}{ Model 1} & \multicolumn{2}{|c|}{ Model 2} & \multicolumn{2}{|c|}{ Model 3} & \multicolumn{2}{|c|}{ Model 4} & \multicolumn{2}{|c|}{ Model 5} \\
\hline & $\begin{array}{l}\text { Odds } \\
\text { Ratios } \\
\end{array}$ & $\begin{array}{c}\text { Conf. } \\
\text { Int }\end{array}$ & $\begin{array}{l}\text { Odds } \\
\text { Ratios } \\
\end{array}$ & Conf. Int & $\begin{array}{l}\text { Odds } \\
\text { Ratios } \\
\end{array}$ & Conf. Int & $\begin{array}{l}\text { Odds } \\
\text { Ratios } \\
\end{array}$ & Conf. Int & $\begin{array}{l}\text { Odds } \\
\text { Ratios } \\
\end{array}$ & Conf. Int \\
\hline Intercept & $\begin{array}{c}3.18 \\
* * *\end{array}$ & $\begin{array}{c}2.13- \\
4.77\end{array}$ & $\begin{array}{c}8.64 \\
* * *\end{array}$ & $\begin{array}{r}2.93- \\
25.46\end{array}$ & 4.43 & $\begin{array}{r}0.43- \\
45.20\end{array}$ & 3.89 & $\begin{array}{r}0.38- \\
39.87\end{array}$ & 4.17 & $\begin{array}{r}0.38- \\
45.97\end{array}$ \\
\hline United States (a) & & & 0.36 & $\begin{array}{c}0.12- \\
1.07\end{array}$ & 0.36 & $\begin{array}{c}0.12- \\
1.08\end{array}$ & 0.36 & $\begin{array}{c}0.12- \\
1.08\end{array}$ & 0.35 & $\begin{array}{c}0.12- \\
1.08\end{array}$ \\
\hline Utah (a) & & & $\begin{array}{l}0.27 \\
*\end{array}$ & $\begin{array}{c}0.08- \\
0.93\end{array}$ & $\begin{array}{l}0.28 \\
*\end{array}$ & $\begin{array}{c}0.08- \\
0.95\end{array}$ & $\begin{array}{c}0.29 \\
*\end{array}$ & $\begin{array}{c}0.08- \\
1.00\end{array}$ & 0.29 & $\begin{array}{c}0.08- \\
1.00\end{array}$ \\
\hline Western States (a) & & & 0.35 & $\begin{array}{c}0.11- \\
1.11\end{array}$ & 0.36 & $\begin{array}{c}0.12- \\
1.15\end{array}$ & 0.37 & $\begin{array}{c}0.12- \\
1.19\end{array}$ & 0.37 & $\begin{array}{c}0.12- \\
1.19\end{array}$ \\
\hline Temperature (C) & & & & & 1.02 & $\begin{array}{c}0.96- \\
1.08\end{array}$ & 1.03 & $\begin{array}{c}0.97- \\
1.09\end{array}$ & 1.03 & $\begin{array}{c}0.97- \\
1.09\end{array}$ \\
\hline $\begin{array}{l}\text { Temperature } \\
\text { Difference (absolute) }\end{array}$ & & & & & & & 1.09 & $\begin{array}{c}1.00- \\
1.18\end{array}$ & 1.09 & $\begin{array}{c}1.00- \\
1.18\end{array}$ \\
\hline Risk Perception & & & & & & & & & 1.00 & $\begin{array}{c}0.99- \\
1.01\end{array}$ \\
\hline \multicolumn{11}{|l|}{ Random Effects } \\
\hline$\sigma^{2}$ & 3.29 & & 3.29 & & 3.29 & & 3.29 & & 3.29 & \\
\hline \multirow[t]{6}{*}{$\tau_{00}$} & \multicolumn{2}{|c|}{0.07 Q20_age } & \multicolumn{2}{|c|}{0.08 Q20_age } & \multicolumn{2}{|c|}{0.07 Q20_age } & \multicolumn{2}{|c|}{0.08 Q20_age } & \multicolumn{2}{|c|}{0.08 Q20_age } \\
\hline & \multicolumn{2}{|c|}{$\begin{array}{l}0.00 \\
\text { Q24_educ_bin }\end{array}$} & \multicolumn{2}{|c|}{$\begin{array}{l}0.00 \\
\text { Q24_educ_bin }\end{array}$} & \multicolumn{2}{|c|}{$\begin{array}{l}0.00 \\
\text { Q24_educ_bin }\end{array}$} & \multicolumn{2}{|c|}{$\begin{array}{l}0.00 \\
\text { Q24_educ_bin }\end{array}$} & \multicolumn{2}{|c|}{$\begin{array}{l}0.00 \\
\text { Q24_educ_bin }\end{array}$} \\
\hline & \multicolumn{2}{|c|}{$\begin{array}{l}0.00 \\
\text { Q21_gender }\end{array}$} & \multicolumn{2}{|c|}{0.00 Q21_gender } & \multicolumn{2}{|c|}{0.00 Q21_gender } & \multicolumn{2}{|c|}{$0.00 \mathrm{Q} 21$ _gender } & \multicolumn{2}{|c|}{0.00 Q21_gender } \\
\hline & \multicolumn{2}{|c|}{$\begin{array}{l}0.00 \\
\text { Q23_race_bin }\end{array}$} & \multicolumn{2}{|c|}{$\begin{array}{l}0.00 \\
\text { Q23 race bin }\end{array}$} & \multicolumn{2}{|c|}{0.00} & \multicolumn{2}{|c|}{0.00} & \multicolumn{2}{|c|}{0.00} \\
\hline & \multicolumn{2}{|c|}{0.02 Trail } & \multicolumn{2}{|c|}{0.01 Trail } & \multicolumn{2}{|c|}{0.00 Trail } & \multicolumn{2}{|c|}{0.00 Trail } & \multicolumn{2}{|c|}{0.00 Trail } \\
\hline & \multicolumn{2}{|c|}{0.00} & $\begin{array}{l}0.00 \\
\text { Q22_his }\end{array}$ & spanic & $\begin{array}{l}0.00 \\
\text { Q22_his }\end{array}$ & spanic & $\begin{array}{l}0.00 \\
\text { Q22_his }\end{array}$ & spanic & $\begin{array}{l}0.00 \\
\text { Q22_his }\end{array}$ & spanic \\
\hline Observations & 328 & & 328 & & 328 & & 328 & & 328 & \\
\hline AIC & 372.16 & & 372.77 & & 374.38 & & 372.61 & & 374.56 & \\
\hline
\end{tabular}

Note. Generalized linear mixed-effect model of carrying more than 1 liter of water. (a) Geographic distance, intercept is 'Non US.' 


\section{DISCUSSION}

Based on my literature review, I hypothesized that participants' thermal perceptions of ambient conditions would be more accurate (align more closely with the instrumental records) if they indicate a geographic origin of a similar environment (hot and arid), if they have spent more time in the region, or if they indicate their most recent 60 minutes has been spent in an outdoor setting. However, none of these hypotheses were confirmed. Geographic features, time in the area, and recent experience did not prove to be an influential predictor of temperature accuracy.

In order to explore my first set research questions, how thermal sensations, thermal perceptions, instrumental records, and geographic attributes relate to each other, I performed a series of linear regressions. This enabled me to explore variable relationships one at a time. Models that used thermal sensations to predict thermal perceptions were not able to explain more than $15 \%$ of the variation. However, models where instrumental records were used to predict thermal perceptions were able to predict $60 \%$ or more of the variation. When exploring how acclimatization (time spent in the region) might predict thermal perceptions, none of the models were able to predict more than $4 \%$ of the variation. Geographic variables were able to explain more of the variation, up to $6.5 \%$, with the Köppen Climate Classification able to explain the most. These linear regressions made it clear that while there is some relationship between the variables of interest, the strongest relationship with thermal perceptions is instrumental records, or the ambient conditions. This aligns with what the linear mixed-effects models found: that temperature is the best predictor of thermal perception. 
In predicting thermal perception, none of the independent variables used in the model strongly predicted temperature estimates except for the instrumental records (temperature (C), dew point (C), and globe temperature (C)). Thus, participants' thermal perception changes as the temperature changes. However, participants were not perfectly accurate when estimating the temperature. By plotting the predictive values for this model's terms (Fig. 1), it's clear that participants were close to accurately predicting the ambient temperature. However, participants are predicted to underestimate the temperature when the temperatures are low, and overestimate when the temperatures are high. For example, when the ambient temperatures were below approximately $35^{\circ} \mathrm{C}\left(95^{\circ} \mathrm{F}\right)$, participants underestimated the temperature. Yet when the temperatures were above $35^{\circ} \mathrm{C}$

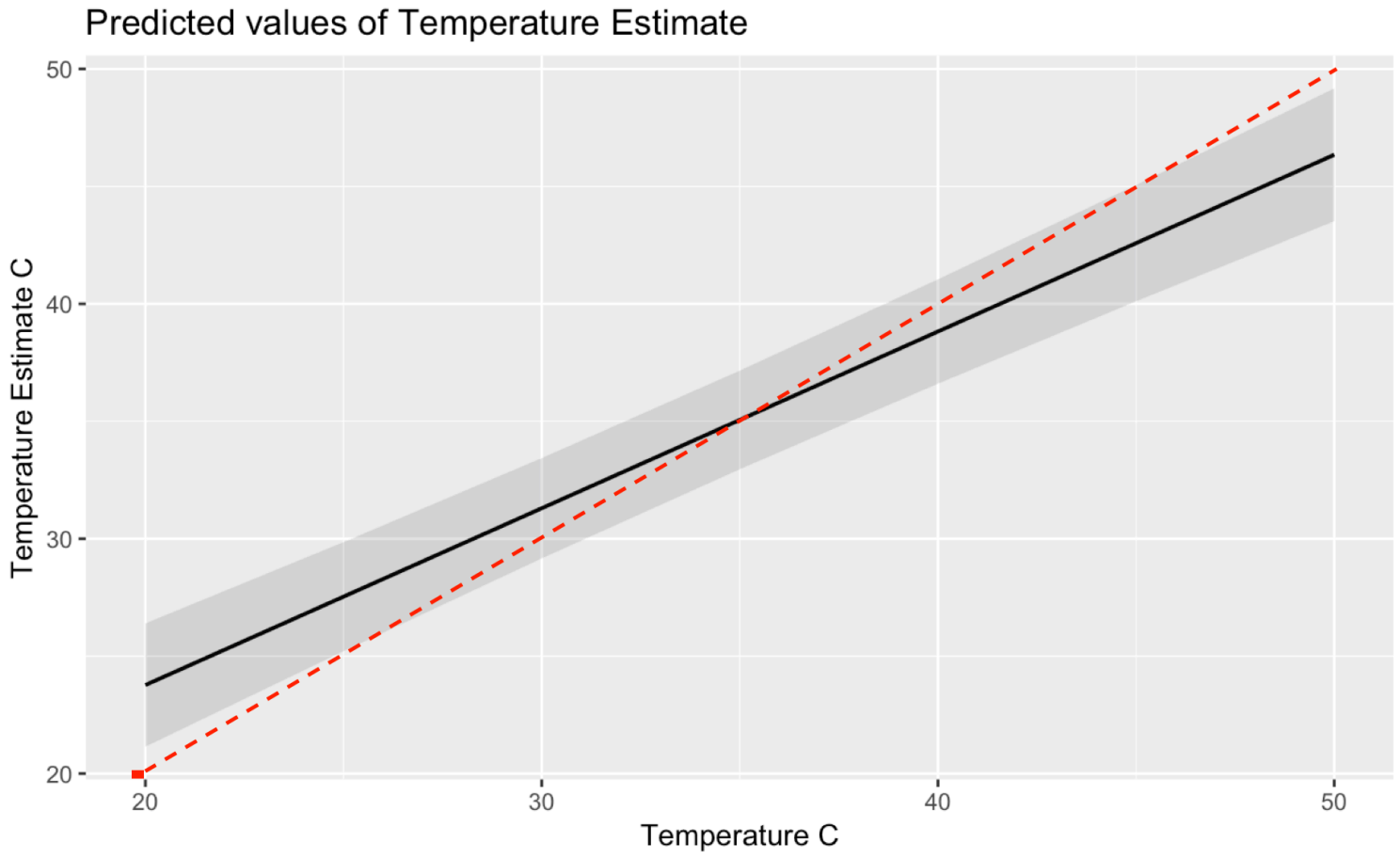

Figure 1. Predicted values of temperature. Predicted temperature values by participates from the linear mixed-effect model of thermal perception, model 5 . The dashed line represents a prefect prediction.

$\left(95^{\circ} \mathrm{F}\right)$, participants underestimate the temperature. The amount by which participants under or overestimate the temperature increase the further the temperature is from $35^{\circ} \mathrm{C}$ 
$\left(95^{\circ} \mathrm{F}\right)$. So, while visitors were close to accurately estimating the temperature, they were not perfectly accurate. This is important for managers and park employees to understand as visitors to the parks may be underestimating severely hot temperatures, and thereby placing themselves at more risk of extreme heat exposure.

In order to answer my second set of research question, how thermal sensations, thermal perceptions, instrumental records, and geographic attributes relate to risk perceptions, I followed the same method as the first set of research questions for the second set. This set of linear regressions showed that there were no clear relationships of how the variables of interest relate to, or predict risk perceptions. I hypothesized that there would be a positive relationship between thermal perceptions and risk perceptions. In other words, that as one's thermal perception increases, so would their risk perception. However, this was not supported. Based on the variables examined in this study, it is still unclear what factors contribute to risk perceptions in this population.

In both the models predicting difference (the absolute difference between a participant's estimated temperature and the actual temperature) and riskp (the average risk perception for participants across all the risk perception questions), temperature, and the other instrumental records, did not significantly predict the dependent variable. These null results are interesting to note as it shows thermal perceptions and risk perceptions are different and change based on different factors. For example, if the temperature increases, so would one's thermal perception, yet a visitor's risk perception does not change. Since temperature is a non-significant factor, it could mean that visitors are again placing themselves at more risk by underestimating the risk of extreme heat. 
From the models predicting riskp, there are trends within the random effects worth bringing attention to. First, "white or caucasian" participants were more likely to have lower risk perception compared to all other racial categories. Second, age did not play a role in predicting risk perception. Despite their greater vulnerability to heat, older populations did not show a higher risk perception of extreme heat. Both of these findings are consistent with other studies that found whites to have lower heat risk perceptions (Howe et al., 2019) and older populations to have similar risk perceptions to younger age groups (Fig. 2) (Esplin, Marlon, Leiserowitz, \& Howe, 2019; Howe et al., 2019). Two

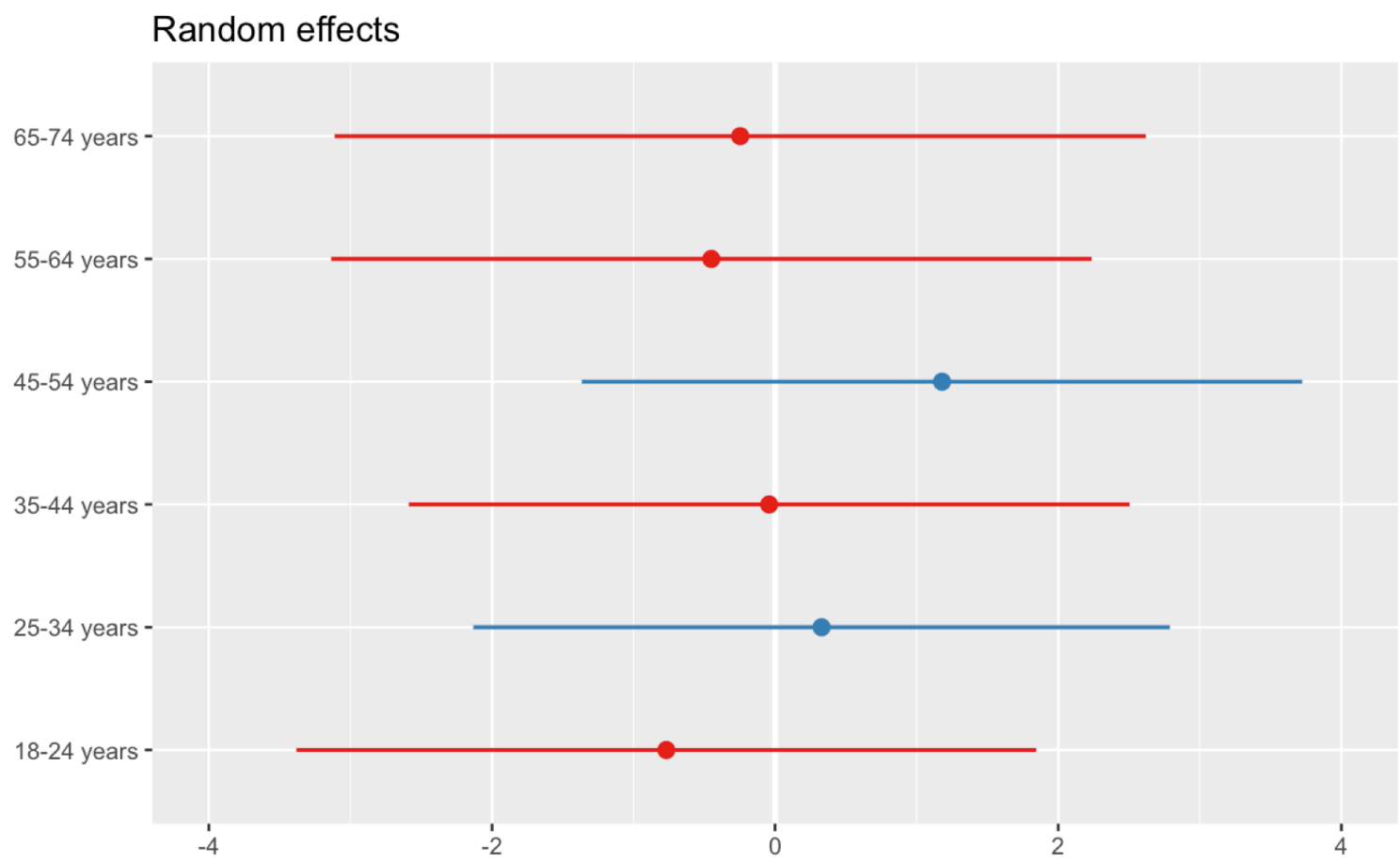

Figure 2. Random effects of age on risk perception. Random effects of age on risk perception. There is little variation across age groups, suggesting that age is not a strong predictive factor of overall risk perception.

trends that did differ from these studies were a difference between genders and between Hispanics and non-Hispanics. While Howe et al. 2019 and Esplin et al. 2019 found women and Hispanics to have higher risk perceptions than men and non-Hispanics, this study did 
not. This is likely a result of this study's small sample size that was less representative of the U.S. Hispanic population.

It is also interesting to note that participants hiking at different trails had different risk perceptions. Those hiking at Corona Arch trail were more likely to have a lower risk perception than those hiking at Delicate Arch trail. I hypothesize this is because those hiking at Corona Arch were more experienced hikers.

Lastly, to answer my third research question, if risk perceptions predict heat protective behaviors, I used two questions from the survey originally intended to provide insightful information to federal land managers. These questions asked if the participant checked the weather conditions for the day, and how much water their respective group was carrying per person. For checking the weather, risk perception proved to be a statistically significant predictor. The higher one's risk perception, the more likely one was to check the weather conditions for the day. However, like the risk perception variable, this action did not show variation across age groups, race, gender, or ethnicity. Additionally, there was not significant variation across these groups when it came to how likely they were to carry more than 1 liter of water. This behavior is the only dependent variable to have shown variation based on a geographic attribute. Utahns were the least likely to carry more than one liter of water. This appears counter intuitive as those most familiar with this area would be expected to practice protective behaviors. However, it is possible that Utahns, due to a greater familiarity with the area and the arid environment, have a false sense of security when it comes to extreme heat.

This study has two primary limitations. First is the relatively small sample size. While the goal of the study was to collect 450 surveys, the final sample size is 105 surveys 
short of that goal. As this study is exploratory, 345 surveys is appropriate for understanding some general trends. Second, there was a relatively small window of time in which to sample in. In total there were only 34 days in which I could conduct intercept surveys. This small window of time, late May to end of June, is in part due to the delay in acquiring the necessary permits required by both the BLM and NPS. This sampling window was in the early summer season, which limited the participants to primarily those traveling for summer vacation. If the survey had been conducted at different times throughout the year, a more robust sample of visitors could have been surveyed. Additionally, this time of the year, while generally hot, is not necessarily the hottest part of the season. Ideally, surveys would have been conducted throughout the summer vacation months (May-August). Further studies should look at larger visitor populations over a longer period, in order to see how perceptions might vary across seasons.

As both heatwaves and extreme heat conditions are predicted to increase in severity, frequency, and area affected in the next century (Jones et al., 2015; Kharin et al., 2007; Mora, Dousset, et al., 2017; Schwartz et al., 2015; USGCRP, 2018) it is extremely relevant to study risk perceptions of this hazard. There is a relationship between where one is from and how one experiences the environment (Basu \& Samet, 2002; Kántor et al., 2016; McGeehin \& Mirabelli, 2001; Sawka, 2015; Shen \& Zhu, 2015). Additionally, we know that how one experiences the environment impacts how one perceives the environment, and thus how one acts in the environment (Bubeck et al., 2012; Grothmann \& Patt, 2005; Lindell \& Perry, 2012). This study set out to see if there is if there is a direct connection between where one is from and risk perceptions of a hot and arid environment. More explicitly, this study set out to explore the relationship between geographic attributes, 
thermal perceptions, thermal sensations, risk perceptions, and instrumental records. I found that while thermal perceptions are accurate and change with temperature, risk perceptions do not change and increase with thermal perceptions. In other words, as temperatures increase risk perceptions are not increasing. This creates a mismatch between these two perceptions.

This study's findings are meaningful for federal land, state land, and private land managers and owners, as it shows that risk perceptions are different from thermal perceptions, and it is yet to be determined how to increase risk perceptions in a hot and arid environment. It also shows that visitors are not more likely to perform protective behaviors on a day with higher temperatures. If extreme heat conditions are not what changes a visitor's protective behavior, the National Park Service and Bureau of Land Management should consider other messaging strategies in order to impact visitors' risk perceptions, as communication strategies to increase risk perceptions and protective behaviors could reduce heat-related health issues and visitor deaths in the Moab area in the next 50 years. 


\section{CONCLUSIONS}

The relationship between people, their physical environments, and their perceptions is a key area of research in human-environment geography. In this tradition, this study explores how people perceive and interact with a hazardous environment; in this case, I explored how visitors perceive and behave in the context of extreme heat in a major desert Southwest outdoor recreation destination. I compared how people perceive temperatures to how they perceive the risks of heat, and I examined how such perceptions vary with exposure to actual changes in temperature and among people from different places and climates. I apply a geographic lens to this research with the purpose of furthering our understanding of risk perceptions of extreme heat events by investigating the relationships between people and their physical environment. It is difficult to predict how people will react and change their perceptions to heat waves and extreme heat, given that this is a relatively new area of research. This study strives to understand attributes that are most reliable at predicting responses to extreme heat risks. This in turn may inform adaptation strategies that will be most effective in protecting human life against extreme heat events.

A key finding of this study is that visitors are not scaling their risk perception with increases in temperature. This imbalance between risk perception and thermal perception puts visitors at greater risk to extreme heat. In order to protect visitors, interventions are necessary. It is important for land managers and park employees to understand how visitors might be scaling their risk perception, as visitors are likely to underestimate severely hot temperatures, placing themselves at more risk of extreme heat exposure.

Another key finding in this study is that risk perceptions of vulnerable populations do not vary from the general population, despite their greater likelihood of being affected 
by extreme heat (Abrahamson et al., 2009; Mora, Counsell, et al., 2017). This null finding is significant because it could influence how the National Park Service and Bureau of Land Management frames their risk messaging going forwards. If the risk perceptions of more vulnerable populations do not vary from those of less vulnerable populations, such agencies could consider messaging more targeted to those populations about their greater risk of being affected by extreme heat.

The third key finding from this study is that people are not more likely to perform protective behaviors even on days of higher temperatures. This finding should be especially important for land managers of hot and arid environments. It shows that even on hotter days, visitors are not more likely to protect themselves from the heat more than any given day.

As dangerous as it can be to visit public lands in times of extreme heat, it is still a beautiful and wondrous location to explore. Public lands management agencies should not seek to keep people out of these areas, which would go against their mission to preserve and protect lands for the public. However, in order to protect the very people who own the land, these agencies should continue to adapt their communication methods using the best available evidence.

The National Park Service is trying two new strategies to protect visitors from the extreme heat in this study area. First, a sign roughly 10 feet onto the trail of Delicate Arch at Arches National Park warns visitors about the dangers of hiking in the middle of the day, that there is little shade, and to carry 2 or more liters of water. Second, a volunteer ranger stands near the sign and stops to talk with people before they start hiking to see if they understand the risks, know how far and long the hike will take, and if they are carrying the 
recommended amount of water. While the NPS was unable to objectively confirm if these two new approaches have saved lives or prevented heat-related illness on the Delicate Arch trail, rangers have subjectively noted that it has made a difference in the number of search and rescues they have performed in years following the implementation of these two new strategies. However, at the Bureau of Land Management's Corona Arch trail, no new program has been implemented to warn or protect visitors about the risks of extreme heat. Expanded risk communication activities, such as those begun by the NPS at Delicate Arch, could likely benefit many more users across other public lands. Such actions are necessary to educate visitors about the risks of extreme heat with the goal of changing their risk perception while engaged in outdoor recreation.

To conclude, these findings should be of importance to managers of local outdoor recreation and public lands management agencies, (e.g., the National Park Service, the Bureau of Land Management), public health officials, and emergency responders, and even private land holders, for further consideration when creating outreach and informative programs designed to protect visitors from extreme heat. 


\section{REFERENCES}

"100 percent avoidable": Hiker deaths mount in blazing Arizona heat wave. (2016). Retrieved May 14, 2018, from The Salt Lake Tribune website: http://archive.sltrib.com/article.php?id=4035101\&itype=CMSID

Abrahamson, V., Wolf, J., Lorenzoni, I., Fenn, B., Kovats, S., Wilkinson, P., ... Raine, R. (2009). Perceptions of heatwave risks to health: Interview-based study of older people in London and Norwich, UK. Journal of Public Health, 31(1), 119-126. https://doi.org/10.1093/pubmed/fdn102

Akompab, D. A., Bi, P., Williams, S., Grant, J., Walker, I. A., \& Augoustinos, M. (2013). Heat Waves and Climate Change: Applying the Health Belief Model to Identify Predictors of Risk Perception and Adaptive Behaviours in Adelaide, Australia. International Journal of Environmental Research and Public Health, 10(6), 2164-2184. https://doi.org/10.3390/ijerph10062164

Barriopedro, D., Fischer, E. M., Luterbacher, J., Trigo, R. M., \& Garcia-Herrera, R. (2011). The Hot Summer of 2010: Redrawing the Temperature Record Map of Europe. Science, 332(6026), 220-224. https://doi.org/10.1126/science.1201224

Basu, R., \& Samet, J. M. (2002). Relation between Elevated Ambient Temperature and Mortality: A Review of the Epidemiologic Evidence. Epidemiologic Reviews, 24(2), 190-202. https://doi.org/10.1093/epirev/mxf007

Bates, D., Mächler, M., Bolker, B., \& Walker, S. (2015). Fitting Linear Mixed-Effects Models Using lme4. Journal of Statistical Software, 67(1), 1-48. https://doi.org/10.18637/jss.v067.i01 
Bobb, J. F., Peng, R. D., Bell, M. L., \& Dominici, F. (2014). Heat-Related Mortality and Adaptation to Heat in the United States. Environmental Health Perspectives. https://doi.org/10.1289/ehp.1307392

Bolin, R., \& Stanford, L. (1998). The Northridge Earthquake: Community-based Approaches to Unmet Recovery Needs. Disasters, 22(1), 21-38. https://doi.org/10.1111/1467-7717.00073

Brager, G. S., \& de Dear, R. J. (1998). Thermal adaptation in the built environment: A literature review. Energy and Buildings, 27(1), 83-96. https://doi.org/10.1016/S0378-7788(97)00053-4

Bubeck, P., Botzen, W. J. W., \& Aerts, J. C. J. H. (2012). A Review of Risk Perceptions and Other Factors that Influence Flood Mitigation Behavior. Risk Analysis, 32(9), 1481-1495. https://doi.org/10.1111/j.1539-6924.2011.01783.x

Chen, L., \& Ng, E. (2012). Outdoor thermal comfort and outdoor activities: A review of research in the past decade. Cities, 29(2), 118-125. https://doi.org/10.1016/j.cities.2011.08.006

Cheuvront, S. N., Kenefick, R. W., Montain, S. J., \& Sawka, M. N. (2010). Mechanisms of aerobic performance impairment with heat stress and dehydration. Journal of Applied Physiology, 109(6), 1989-1995. https://doi.org/10.1152/japplphysiol.00367.2010

Colten, C. E., \& Sumpter, A. R. (2009). Social memory and resilience in New Orleans. Natural Hazards, 48(3), 355-364. https://doi.org/10.1007/s11069-008-9267-x

Corona Arch Trail. (n.d.). Retrieved February 20, 2019, from https://www.blm.gov/visit/corona-arch-trail 
Cutter, S. L. (1996). Vulnerability to environmental hazards. Progress in Human Geography, 20(4), 529-539. https://doi.org/10.1177/030913259602000407

De Urioste-Stone, S. M., Scaccia, M. D., \& Howe-Poteet, D. (2015). Exploring visitor perceptions of the influence of climate change on tourism at Acadia National Park, Maine. Journal of Outdoor Recreation and Tourism, 11, 34-43. https://doi.org/10.1016/j.jort.2015.07.001

Dear, R. de, \& Brager, G. S. (2001). The adaptive model of thermal comfort and energy conservation in the built environment. International Journal of Biometeorology, 45(2), 100-108. https://doi.org/10.1007/s004840100093

El Fadli, K. I., Cerveny, R. S., Burt, C. C., Eden, P., Parker, D., Brunet, M., ... Pace, M. B. (2013). World Meteorological Organization Assessment of the Purported World Record $58^{\circ} \mathrm{C}$ Temperature Extreme at El Azizia, Libya (13 September 1922). Bulletin of the American Meteorological Society, 94(2), 199-204. https://doi.org/10.1175/BAMS-D-12-00093.1

Esplin, E. D., Marlon, J. R., Leiserowitz, A., \& Howe, P. D. (2019). "Can You Take the Heat?" Heat-Induced Health Symptoms Are Associated with Protective Behaviors. Weather, Climate, and Society, 11(2), 401-417. https://doi.org/10.1175/WCAS-D-18-0035.1

ESRI, \& NOAA. (2016). Future Heat Events and Social Vulnerability. Retrieved May 1, 2018, from https://maps.esri.com/jg/HeatVulnerability/index.html

Freitas, C. R. de. (2003). Tourism climatology: Evaluating environmental information for decision making and business planning in the recreation and tourism sector. 
International Journal of Biometeorology, 48(1), 45-54.

https://doi.org/10.1007/s00484-003-0177-z

Gregory, D., Johnston, R., Geraldine, P., Watts, M. J., \& Wathmore, S. (Eds.). (2013).

The Dictionary of Human Geography (5th ed.). Wiley-Blackwell.

Grothmann, T., \& Patt, A. (2005). Adaptive capacity and human cognition: The process of individual adaptation to climate change. Global Environmental Change, 15(3), 199-213. https://doi.org/10.1016/j.gloenvcha.2005.01.002

Grumm, R. H. (2011). The central European and Russian heat event of July-August 2010. Bulletin of the American Meteorological Society, 92(10), 1285-1296.

Harlan, S. L., Brazel, A. J., Prashad, L., Stefanov, W. L., \& Larsen, L. (2006). Neighborhood microclimates and vulnerability to heat stress. Social Science \& Medicine, 63(11), 2847-2863. https://doi.org/10.1016/j.socscimed.2006.07.030

Heatstroke and Heat Exhaustion. (n.d.). Retrieved May 14, 2018, from http://www.utahmountainbiking.com/firstaid/heatstrok.htm

Hitchings, R. (2011). Coping with the immediate experience of climate: Regional variations and indoor trajectories. Wiley Interdisciplinary Reviews: Climate Change, 2(2), 170-184. https://doi.org/10.1002/wcc.106

Höppe, P. (2002). Different aspects of assessing indoor and outdoor thermal comfort. Energy and Buildings, 34(6), 661-665. https://doi.org/10.1016/S0378$7788(02) 00017-8$

Howe, P. D., Marlon, J. R., Wang, X., \& Leiserowitz, A. (2019). Public perceptions of the health risks of extreme heat across US states, counties, and neighborhoods. 
Proceedings of the National Academy of Sciences, 116(14), 6743-6748. https://doi.org/10.1073/pnas.1813145116

Jóhannesdóttir, G., \& Gísladóttir, G. (2010). People living under threat of volcanic hazard in southern Iceland: Vulnerability and risk perception. Nat. Hazards Earth Syst. Sci., 10(2), 407-420. https://doi.org/10.5194/nhess-10-407-2010

Johansson, E., Thorsson, S., Emmanuel, R., \& Krüger, E. (2014). Instruments and methods in outdoor thermal comfort studies - The need for standardization. Urban Climate, 10, 346-366. https://doi.org/10.1016/j.uclim.2013.12.002 Jones, B., O’Neill, B. C., McDaniel, L., McGinnis, S., Mearns, L. O., \& Tebaldi, C. (2015). Future population exposure to US heat extremes. Nature Climate Change, 5(7), 652-655. https://doi.org/10.1038/nclimate2631

Kántor, N., Kovács, A., \& Takács, Á. (2016). Seasonal differences in the subjective assessment of outdoor thermal conditions and the impact of analysis techniques on the obtained results. International Journal of Biometeorology, 60(11), 16151635. https://doi.org/10.1007/s00484-016-1151-x

Keeping your cool in summer. (2013). Retrieved May 14, 2018, from Moabnewssun.com website: http://www.moabsunnews.com/get_out_and_go/article_1c5d0dde-f94e11e2-afab-001a4bcf6878.html

Kharin, V. V., Zwiers, F. W., Zhang, X., \& Hegerl, G. C. (2007). Changes in Temperature and Precipitation Extremes in the IPCC Ensemble of Global Coupled Model Simulations. Journal of Climate, 20(8), 1419-1444. https://doi.org/10.1175/JCLI4066.1 
Knez, I., Thorsson, S., Eliasson, I., \& Lindberg, F. (2009). Psychological mechanisms in outdoor place and weather assessment: Towards a conceptual model. International Journal of Biometeorology, 53(1), 101-111. https://doi.org/10.1007/s00484-008-0194-z

Kuras, E. R., Hondula, D. M., \& Brown-Saracino, J. (2015). Heterogeneity in individually experienced temperatures (IETs) within an urban neighborhood: Insights from a new approach to measuring heat exposure. International Journal of Biometeorology, 59(10), 1363-1372. https://doi.org/10.1007/s00484-014-0946$\mathrm{x}$

KUTV, L. D. C. (2017, June 15). Excessive heat watch issued for southern Utah. Retrieved May 14, 2018, from KUTV website: http://kutv.com/news/local/excessive-heat-watch-issued-for-southern-utah

Lai, D., Guo, D., Hou, Y., Lin, C., \& Chen, Q. (2014). Studies of outdoor thermal comfort in northern China. Building and Environment, 77, 110-118. https://doi.org/10.1016/j.buildenv.2014.03.026

Lam, C. K. C., Loughnan, M., \& Tapper, N. (2016). Visitors' perception of thermal comfort during extreme heat events at the Royal Botanic Garden Melbourne. International Journal of Biometeorology, 62(1), 97-112. https://doi.org/10.1007/s00484-015-1125-4

Lépy, É., Heikkinen, H. I., Karjalainen, T. P., Tervo-Kankare, K., Kauppila, P., Suopajärvi, T., ... Rautio, A. (2014). Multidisciplinary and Participatory Approach for Assessing Local Vulnerability of Tourism Industry to Climate 
Change. Scandinavian Journal of Hospitality and Tourism, 14(1), 41-59.

https://doi.org/10.1080/15022250.2014.886373

Lin, T.-P. (2009). Thermal perception, adaptation and attendance in a public square in hot and humid regions. Building and Environment, 44(10), 2017-2026.

https://doi.org/10.1016/j.buildenv.2009.02.004

Lindell, M. K., \& Perry, R. W. (2012). The Protective Action Decision Model:

Theoretical Modifications and Additional Evidence. Risk Analysis, 32(4), 616632. https://doi.org/10.1111/j.1539-6924.2011.01647.x

Lopez, H., West, R., Dong, S., Goni, G., Kirtman, B., Lee, S.-K., \& Atlas, R. (2018). Early emergence of anthropogenically forced heat waves in the western United States and Great Lakes. Nature Climate Change, 8.

Lüdecke, D., \& Schwemmer, C. (2018). sjPlot: Data Visualization for Statistics in Social Science (Version 2.6.2). Retrieved from https://CRAN.Rproject.org/package $=$ sjPlot

Lujala, P., Lein, H., \& Rød, J. K. (2015). Climate change, natural hazards, and risk perception: The role of proximity and personal experience. Local Environment, 20(4), 489-509. https://doi.org/10.1080/13549839.2014.887666

Mahmoud, A. H. A. (2011). Analysis of the microclimatic and human comfort conditions in an urban park in hot and arid regions. Building and Environment, 46(12), 2641-2656. https://doi.org/10.1016/j.buildenv.2011.06.025

Man found dead at Arches. (2016). Retrieved May 14, 2018, from Moabnewssun.com website: http://www.moabsunnews.com/news/article_5a7b908a-6ad0-11e6-bc8d8379572e4175.html 
Matzarakis, A. (2006). Weather- and climate-related information for tourism. Tourism and Hospitality Planning \& Development, 3(2), 99-115.

https://doi.org/10.1080/14790530600938279

McGeehin, M. A., \& Mirabelli, M. (2001). The potential impacts of climate variability and change on temperature-related morbidity and mortality in the United States. Environmental Health Perspectives, 109(Suppl 2), 185-189.

McMichael, A. J., Woodruff, R. E., \& Hales, S. (2006). Climate change and human health: Present and future risks. The Lancet, 367(9513), 859-869. https://doi.org/10.1016/S0140-6736(06)68079-3

Meehl, G. A., Zwiers, F., Evans, J., Knutson, T., Mearns, L., \& Whetton, P. (2000). Trends in Extreme Weather and Climate Events: Issues Related to Modeling Extremes in Projections of Future Climate Change. Bulletin of the American Meteorological Society, 81(3), 427-436. https://doi.org/10.1175/15200477(2000)081<0427:TIEWAC $>2.3 . \mathrm{CO} ; 2$

Moab, M. A. P. B. 907, \& Us, U. 84532 P.-2299 C. (2017). Park Statisticsâ "Arches National Park (U.S. National Park Service). Retrieved May 7, 2018, from https://www.nps.gov/arch/learn/management/statistics.htm

Montz, B. E., \& Tobin, G. A. (2011a). Natural hazards: An evolving tradition in applied geography. Applied Geography, 31(1), 1-4. https://doi.org/10.1016/j.apgeog.2010.06.005

Montz, B. E., \& Tobin, G. A. (2011b). Natural hazards: An evolving tradition in applied geography. Applied Geography, 31(1), 1-4. https://doi.org/10.1016/j.apgeog.2010.06.005 
Mora, C., Counsell, C. W. W., Bielecki, C. R., \& Louis, L. V. (2017). Twenty-Seven Ways a Heat Wave Can Kill You: Deadly Heat in the Era of Climate Change. Circulation: Cardiovascular Quality and Outcomes, 10(11), e004233. https://doi.org/10.1161/CIRCOUTCOMES.117.004233

Mora, C., Dousset, B., Caldwell, I. R., Powell, F. E., Geronimo, R. C., Bielecki, C. R., ... Trauernicht, C. (2017). Global risk of deadly heat. Nature Climate Change, 7(7), 501. https://doi.org/10.1038/nclimate3322

Morgan, C., \& de Dear, R. (2003). Weather, clothing and thermal adaptation to indoor climate. Climate Research, 24, 267-284. https://doi.org/10.3354/cr024267

Ng, E., \& Cheng, V. (2012). Urban human thermal comfort in hot and humid Hong Kong. Energy and Buildings, 55, 51-65. https://doi.org/10.1016/j.enbuild.2011.09.025

Nikolopoulou, M., Baker, N., \& Steemers, K. (2001). Thermal comfort in outdoor urban spaces: Understanding the human parameter. Solar Energy, 70(3), 227-235. https://doi.org/10.1016/S0038-092X(00)00093-1

NWS. (n.d.). NOAA’s National Weather Serviceâ "Glossary. Retrieved May 17, 2018, from https://forecast.weather.gov/glossary.php?letter=h

NWS Analyze, F. and S. O. (2016). NWS Analyze, Forecast and Support Office. Retrieved May 1, 2018, from http://www.nws.noaa.gov/om/hazstats.shtml O’hare, G., \& Rivas, S. (2005). The landslide hazard and human vulnerability in La Paz City, Bolivia. The Geographical Journal, 171(3), 239-258. https://doi.org/10.1111/j.1475-4959.2005.00163.x 
Pearlmutter, D., Jiao, D., \& Garb, Y. (2014). The relationship between bioclimatic thermal stress and subjective thermal sensation in pedestrian spaces. International Journal of Biometeorology, 58(10), 2111-2127. https://doi.org/10.1007/s00484014-0812-X

Poumadère, M., Mays, C., Le Mer, S., \& Blong, R. (2005). The 2003 Heat Wave in France: Dangerous Climate Change Here and Now: The 2003 Heat Wave in France. Risk Analysis, 25(6), 1483-1494. https://doi.org/10.1111/j.15396924.2005.00694.x

Reid, C., O’Neill, M., Gronlund, C., Brines, S., Brown, D., Diez-Roux, A., \& Schwartz, J. (2009). Mapping Community Determinants of Heat Vulnerability. Environmental Health Perspectives. https://doi.org/10.1289/ehp.0900683

Rohrmann, B., \& Renn, O. (2000). Risk Perception Research. In O. Renn \& B. Rohrmann (Eds.), Cross-Cultural Risk Perception: A Survey of Empirical Studies (pp. 11-53). https://doi.org/10.1007/978-1-4757-4891-8_1

Rutty, M., \& Scott, D. (2015). Bioclimatic comfort and the thermal perceptions and preferences of beach tourists. International Journal of Biometeorology, 59(1), 3745. https://doi.org/10.1007/s00484-014-0820-X

Sawka, M. N. (2015). Heat acclimatization to improve an athletic performance in warmhot environments. 28(153), 7.

Sawka, M. N., Leon, L. R., Montain, S. J., \& Sonna, L. A. (2011). Integrated Physiological Mechanisms of Exercise Performance, Adaptation, and Maladaptation to Heat Stress. In Comprehensive Physiology (pp. 1883-1928). https://doi.org/10.1002/cphy.c100082 
Schums, A. V. (2018, December 16). National Park Ranger Interview [Phone].

Schwartz, J. D., Lee, M., Kinney, P. L., Yang, S., Mills, D., Sarofim, M. C., ... Horton, R. M. (2015). Projections of temperature-attributable premature deaths in 209 U.S. cities using a cluster-based Poisson approach. Environmental Health, 14, 85. https://doi.org/10.1186/s12940-015-0071-2

Shen, D., \& Zhu, N. (2015). Influence of the temperature and relative humidity on human heat acclimatization during training in extremely hot environments. Building and Environment, 94, 1-11. https://doi.org/10.1016/j.buildenv.2015.07.023

Sheridan, S. C. (2007). A survey of public perception and response to heat warnings across four North American cities: An evaluation of municipal effectiveness. International Journal of Biometeorology, 52(1), 3-15. https://doi.org/10.1007/s00484-006-0052-9

Sheridan, S. C., \& Dixon, P. G. (2017). Spatiotemporal trends in human vulnerability and adaptation to heat across the United States. Anthropocene, 20, 61-73. https://doi.org/10.1016/j.ancene.2016.10.001

Simmons, K. M., \& Sutter, D. (2011). Going Forward: Using Societal Impacts Research to Reduce Tornado Risk. In Economic and Societal Impacts of Tornadoes (pp. 243-257). https://doi.org/10.1007/978-1-935704-02-7_7

Slovic, P., \& Peters, E. (2006). Risk Perception and Affect. Current Directions in Psychological Science, 15(6), 322-325. https://doi.org/10.1111/j.14678721.2006.00461.x

Smith, K. (2013). Environmental Hazards: Assessing Risk and Reducing Disaster (6th Edition). Routledge. 
Son, J.-Y., Lee, J.-T., Anderson, G. B., \& Bell, M. L. (2011). Vulnerability to temperature-related mortality in Seoul, Korea. Environmental Research Letters, 6(3), 034027. https://doi.org/10.1088/1748-9326/6/3/034027

Spagnolo, J., \& de Dear, R. (2003). A field study of thermal comfort in outdoor and semioutdoor environments in subtropical Sydney Australia. Building and Environment, 38(5), 721-738. https://doi.org/10.1016/S0360-1323(02)00209-3

Stilson, A. (2017, June 19). Heat hitting Utah early; record highs expected. Retrieved May 14, 2018, from DeseretNews.com website: https://www.deseretnews.com/article/865683276/Heat-hitting-Utah-early-recordhighs-expected.html

Toulemon, L., \& Barbieri, M. (2008). The mortality impact of the August 2003 heat wave in France: Investigating the 'harvesting' effect and other long-term consequences. Population Studies, 62(1), 39-53. https://doi.org/10.1080/00324720701804249

U. S. Census Bureau. (2017). American FactFinderâ "Results. Retrieved April 9, 2019, from https://factfinder.census.gov/faces/tableservices/jsf/pages/productview.xhtml?src= bkmk

U. S. Census Bureau. (2018a). American FactFinderâ "Results. Retrieved April 9, 2019, from https:/factfinder.census.gov/faces/tableservices/jsf/pages/productview.xhtml?pid $=$ PEP_2018_PEPANNRES\&prodType $=$ table

U. S. Census Bureau. (2018b). Cartographic Boundary Shapefilesâ "States. Retrieved May 4, 2018, from https://www.census.gov/geo/maps-data/data/cbf/cbf_state.html 
USGCRP. (2018). Fourth National Climate Assessment. Retrieved December 19, 2018, from https://nca2018.globalchange.gov

Wachinger, G., Renn, O., Begg, C., \& Kuhlicke, C. (2013). The Risk Perception Paradox-Implications for Governance and Communication of Natural Hazards. Risk Analysis, 33(6), 1049-1065. https://doi.org/10.1111/j.15396924.2012.01942.x

Wallace, J. W., Poole, C., \& Horney, J. A. (2016). The association between actual and perceived flood risk and evacuation from Hurricane Irene, Beaufort County, North Carolina. Journal of Flood Risk Management, 9(2), 125-135. https://doi.org/10.1111/jfr3.12115

Woman found dead at Arches. (2016). Retrieved May 1, 2018, from Moabnewssun.com website: http://www.moabsunnews.com/news/article_1f849476-3e4e-11e6-8bbe7b29ead79560.html

Yin, J., Zheng, Y., Wu, R., Tan, J., Ye, D., \& Wang, W. (2012). An analysis of influential factors on outdoor thermal comfort in summer. International Journal of Biometeorology, 56(5), 941-948. https://doi.org/10.1007/s00484-011-0503-9 
APPENDICES 


\section{APPENDIX A}

\section{SURVEY QUESTIONS}

Survey questions, possible answers, and explanations for why the question was included in the survey.

\begin{tabular}{|c|c|}
\hline Question & Possible answers \\
\hline 1. Where do you currently live? & $\begin{array}{l}\text { City, town or country, State or province, } \\
\text { ZIP or postal code, Country }\end{array}$ \\
\hline \multicolumn{2}{|c|}{$\begin{array}{l}\text { This will establish the participant's geographic origin and it will be used as a } \\
\text { geographic variable in the models. }\end{array}$} \\
\hline $\begin{array}{l}\text { 2. How long have you lived at the above } \\
\text { location? }\end{array}$ & Number of years in a space provided. \\
\hline \multicolumn{2}{|c|}{ This indicates the participant's long-term acclimatization. } \\
\hline $\begin{array}{l}\text { 3. How many days have you been in this } \\
\text { region, including Utah, Colorado, New } \\
\text { Mexico, Arizona, and Nevada? }\end{array}$ & $\begin{array}{l}\text { Less than } 1 \text { day, 1-7 days, } 8-14 \text { days, } 14+ \\
\text { days }\end{array}$ \\
\hline \multicolumn{2}{|c|}{$\begin{array}{l}\text { Similar to Q3, this indicates the participant's short-term acclimatization to the current } \\
\text { environment. }\end{array}$} \\
\hline 4. How often do you exercise? & Regularly, Occasionally, Rarely, Never \\
\hline \multicolumn{2}{|c|}{$\begin{array}{l}\text { This question asks participants to measure their physical fitness. It will be used to } \\
\text { understand one's ability to complete physical tasks without undue fatigue. }\end{array}$} \\
\hline $\begin{array}{l}\text { 5. In the last } 60 \text { minutes, where have you } \\
\text { primarily been? }\end{array}$ & $\begin{array}{l}\text { In the car (with air conditioning), In the } \\
\text { car (without air conditioning), Outside } \\
\text { (hiking or doing other physical activity), } \\
\text { Outside (mostly seated), Inside (in the } \\
\text { Visitor Center or another building) }\end{array}$ \\
\hline \multicolumn{2}{|c|}{$\begin{array}{l}\text { With this question we can understand the participants' immediate thermal experience, } \\
\text { which could impact their thermal sensation during the survey. }\end{array}$} \\
\hline 6. Have you done this hike before? & Yes, No \\
\hline \multicolumn{2}{|c|}{$\begin{array}{l}\text { This question is included with the aim of being beneficial to the BLM and park service, } \\
\text { in so much as they can understand how many people repeat the hike. }\end{array}$} \\
\hline $\begin{array}{l}\text { 7. How long do you think this hike will } \\
\text { take (including time at the destination)? }\end{array}$ & $\begin{array}{l}\text { Number of hours and minutes in a space } \\
\text { provided. }\end{array}$ \\
\hline \multicolumn{2}{|c|}{$\begin{array}{l}\text { This is also included with the aim of being beneficial to the BLM and park service. } \\
\text { From this estimation of how long people believe the hike will take them, the park } \\
\text { service could emphasize more or less in messages about the actual duration of the hike. }\end{array}$} \\
\hline
\end{tabular}




\begin{tabular}{|l|l|}
\hline $\begin{array}{l}\text { 8. How many liters of water, per person, is } \\
\text { your group carrying? }\end{array}$ & $\begin{array}{l}\text { None, Less than } 1 / 2 \text { liter, } 1 / 2 \text { to } 1 \\
\text { liters, 2-3 liters, More than } 3 \text { lit }\end{array}$ \\
\hline $\begin{array}{l}\text { This behavioral measure will be used to understand a participant's preparedn } \\
\text { protective behavior. Likewise, it could be helpful the BLM and park service } \\
\text { understand how prepared hikers are. }\end{array}$ \\
\hline $\begin{array}{l}\text { 9. What do you think the outside } \\
\text { temperature is right now? }\end{array}$ & $\begin{array}{l}\text { An X placed on a thermometer } \\
\text { (Fahrenheit and Celsius) }\end{array}$ \\
\hline
\end{tabular}

This is to measure the participant's thermal perception, by understanding what the participant believes the current temperature to be. I will also calculate a difference of the actual temperature and the perceived temperature.

\begin{tabular}{l|l}
$\begin{array}{l}\text { 10. How does the current temperature } \\
\text { compare to typical weather for this time of } \\
\text { year where you currently live? }\end{array}$ & $\begin{array}{l}\text { Colder than where I live, Similar to } \\
\text { where I live, Hotter than where I live }\end{array}$ \\
\hline
\end{tabular}

This is a measurement of the participant's thermal sensation.

\begin{tabular}{l|l}
$\begin{array}{l}\text { 11. Please describe how you are feeling } \\
\text { right now: }\end{array}$ & $\begin{array}{l}\text { Cold, Cool, Slightly Cool, Neutral, } \\
\text { Slightly Warm, Warm, Hot }\end{array}$ \\
\hline
\end{tabular}

This is a measurement of the participant's thermal sensation.

\begin{tabular}{|l|l} 
12. Do you find this environment... & Very Uncomfortable, Uncomfortable,
\end{tabular} Acceptable, Comfortable, Very

Comfortable

This is a measurement of the participant's thermal sensation.

13. A heat wave is a period of unusually and uncomfortably hot weather. If a heat wave were to occur here, how much, if at all, do you think it would harm the following?

This question measures one aspect of risk perception, severity, for a heatwave in the Moab area.

14. A heat wave is a period of unusually and uncomfortably hot weather. If a heat wave were to occur in your local area (where you live), how much, if at all, do you think it would harm the following?
An X placed on a scale from $0 \%$ to $100 \%$ for both their health and their community's health.

This question measures one aspect of risk perception, severity, for a heatwave where the participants' local area.

15. How worried, if at all, are you about the effects of heat waves on the following?

An X placed on a scale from $0 \%$ to $100 \%$ for both their health and their community's health.

This question measures another aspect of risk perception, affect. 


\begin{tabular}{|c|c|}
\hline $\begin{array}{l}\text { 16. How often have you experienced the } \\
\text { following effects of heat in the past year } \\
\text { a. Decreased productivity at work, b. } \\
\text { Personal discomfort, c. Heat-related } \\
\text { illness, such as heat exhaustion or heat } \\
\text { stroke. }\end{array}$ & Never, Rarely, Occasionally, Often \\
\hline \multicolumn{2}{|c|}{$\begin{array}{l}\text { These questions will provide an understanding of their medical history, and previous } \\
\text { experience with the impacts of extreme heat. }\end{array}$} \\
\hline $\begin{array}{l}\text { 17. Have you received or heard } \\
\text { information about what to do during hot } \\
\text { weather since entering the area? }\end{array}$ & Yes, No \\
\hline \multicolumn{2}{|c|}{$\begin{array}{l}\text { This question is not intended to measure the effectiveness of any current } \\
\text { communication strategies. Instead it is included with the aim to notify the park service } \\
\text { and public health officials about how visible warnings about extreme heat are } \\
\text { currently. }\end{array}$} \\
\hline $\begin{array}{l}\text { 18. Did you check the weather conditions } \\
\text { for today? }\end{array}$ & Yes, No \\
\hline \multicolumn{2}{|c|}{$\begin{array}{l}\text { This behavioral measure will be used to understand a participant's preparedness, a } \\
\text { protective behavior. Likewise, it could be helpful the park service to understand how } \\
\text { prepared hikers are. }\end{array}$} \\
\hline 19.1. How many people are in your group? & Number of people in a space provided. \\
\hline 19.2. How many in your group are: & $\begin{array}{l}\text { Number provide for each: less than } 5 \\
\text { years old, } 5-18 \text { years old, } 19-64 \text { years } \\
\text { old, older than } 65\end{array}$ \\
\hline \multicolumn{2}{|c|}{$\begin{array}{l}\text { This two-part question is designed to measure the groups' size and age composition. } \\
\text { Additionally, it could help the park service understand what the ages of a typical hiking } \\
\text { group are. }\end{array}$} \\
\hline
\end{tabular}




\begin{tabular}{|l|l|}
\hline \multicolumn{2}{|l|}{ The following questions are included to collect the demographics of each participant. } \\
\hline 20. What is your age? & $\begin{array}{l}18-24 \text { years old, 25-34 years old, 35-44 } \\
\text { years old, 45-54 years old, 55-64 years } \\
\text { old, 65-74 years old, 75 years or older }\end{array}$ \\
\hline 21. Are you... & $\begin{array}{l}\text { Male, Female, Non-binary or third } \\
\text { gender/Prefer to self-describe }\end{array}$ \\
\hline $\begin{array}{l}\text { 22. Are you of Spanish, Hispanic or Latino } \\
\text { descent? }\end{array}$ & Yes, No \\
\hline $\begin{array}{l}\text { 23. Which race or ethnic background best } \\
\text { describes you? }\end{array}$ & $\begin{array}{l}\text { African American or Black, Asian, } \\
\text { American Indian or Alaska Native, } \\
\text { Native Hawaiian or Pacific Islander, } \\
\text { White or Caucasian, Other }\end{array}$ \\
\hline $\begin{array}{l}\text { 24. What is the highest level of school you } \\
\text { have completed? }\end{array}$ & $\begin{array}{l}\text { Less than high school, Some high school, } \\
\text { no diploma, High school graduate or } \\
\text { GED, Some college, no degree, } \\
\text { Associate degree, Bachelor's degree, } \\
\text { Master's, professional or doctorate } \\
\text { degree }\end{array}$ \\
\hline
\end{tabular}




\section{APPENDIX B}

\section{SURVEY WITH LETTER OF INFORMATION FOR PARTICIPANTS}

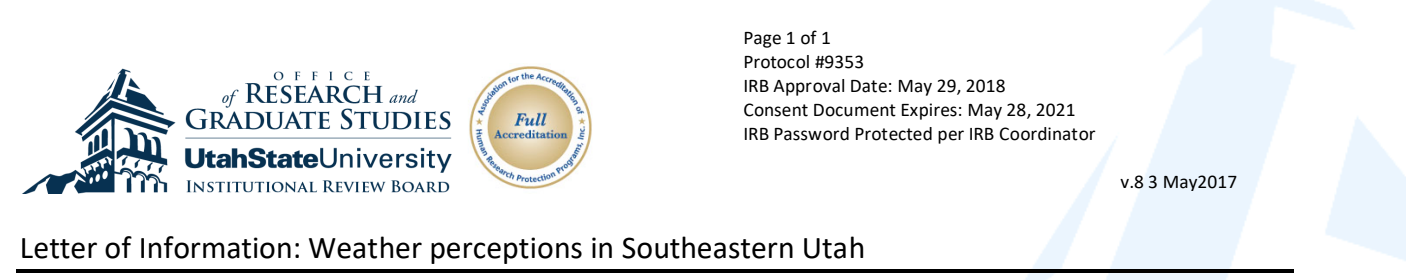

Dr. Peter Howe and Kirsten Goldstein, researchers from Utah State University, are doing a survey research study about how people perceive summer weather in Southeastern Utah.

If you would like to be a part of this study, you will take a survey before your hike, which will take approximately $\mathbf{7}$ minutes. If you have already participated in this survey, please return this survey to the researcher, indicating you have already participated.

This is a minimal risk research study. The risks of participating are no more likely or serious than those you encounter in everyday activities. There is a small risk of loss of confidentiality.

This study will help us learn more about how people respond to weather and how to communicate about weather conditions more effectively in the future.

Your participation in this study is anonymous. Your identity will not be collected and therefore cannot be revealed in any publications resulting from this research study. No video, photo images, or audio recordings will be made.

Your participation is completely voluntary. If you do not wish to participate you may withdraw by returning this survey to the researcher, indicating you do not wish to participate.

For your participation in this research study, you will receive a travel-size tube of sunscreen. You will receive this after you have completed the survey.

By continuing on to the survey, you agree to participate in this study. You indicate that you understand the risks and benefits of participation, and that you know what you will be asked to do. You also agree that you have asked any questions you might have, and are clear on how to stop your participation in the study if you choose to do so. You may keep a copy of this letter for your records. If you would like to be in this study, and are 18 years of age or older, please continue to the survey on the next page.

\section{IRB Review}

The Institutional Review Board (IRB) for the protection of human research participants at Utah State University has reviewed and approved this study. If you have questions about the research study itself, please contact the Principal Investigator at (435) 797-9457 or peter.howe@usu.edu. If you have questions about your rights or would simply like to speak with someone other than the research team about questions or concerns, please contact the IRB Director at (435) 797-0567 or irb@usu.edu.

Peter D. Howe, Ph.D.

Assistant Professor of Geography

Utah State University

Principal Investigator

(435) 797-9457; peter.howe@usu.edu
Kirsten Goldstein

Graduate Student of Geography

Utah State University

Co-Investigator

(320) 296-1909; kgoldstein@aggiemail.usu.edu

Department of Environment and Society | 435-797-1790 ｜ 5215 Old Main Hill ｜ Logan, UT 84322 


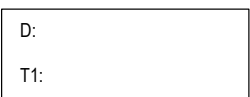

1. Where do you currently live?

City, town, or county:

State or province:

ZIP or postal code:

Country:

2. How long have you lived at the above location?

years

3. How many days have you been in this region, including Utah, Colorado, New Mexico, Arizona, and Nevada? (circle one)
Less than 1 day
1-7 days
8-14 days
$14+$ days

4. How often do you exercise? (circle one)

Regularly Occasionally Rarely Never

5. In the last $\mathbf{6 0}$ minutes, where have you primarily been? (circle one)

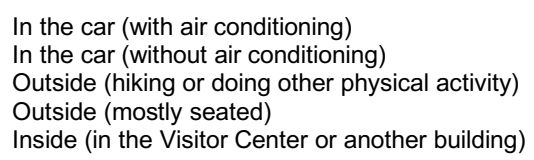

6. Have you done this hike before? (circle one)

Yes No

7. How long do you think this hike will take (including time at the destination)?

hours minutes

8. How many liters of water, per person, is your group carrying?

Please circle your best estimate.

None Less than $1 / 2$ liter $\quad 1 / 2$ to 1 liter $\quad 1-2$ liters $\quad 2-3$ liters $\quad$ More than 3 liters

Please provide your best guess for the following questions without referring to personal electronics or outside information:

9. What do you think the outside temperature is right now? Indicate your best estimate by placing an X mark on the scale below.

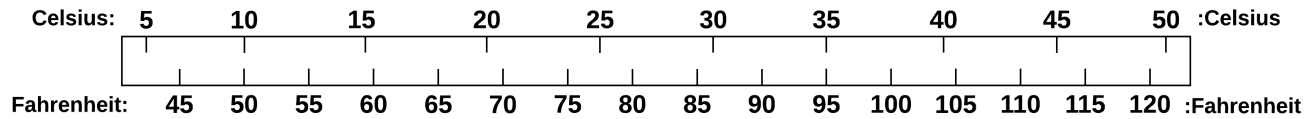

10. How does the current temperature here compare to typical weather for this time of year where you currently live? (circle one)

\begin{tabular}{l|l|l} 
Colder than where I live & Similar to where I live & Hotter than where I live
\end{tabular}

Continue to next page 
11. Please describe how you are feeling right now: (circle one)

Cold $\mid$ Cool $\mid$ Slightly Cool $\mid$ Neutral $\mid$ Slightly Warm $\mid$ Warm $\mid$ Hot

12. Do you find this environment... (circle one)

\begin{tabular}{l|l|l|l|l} 
Very Uncomfortable & Uncomfortable & Acceptable & Comfortable & Very Comfortable
\end{tabular}

13. A heat wave is a period of unusually and uncomfortably hot weather. If a heat wave were to occur here, how much, if at all, do you think it would harm the following?

Provide your best estimate by placing an X mark on the scale below for each item.

\begin{tabular}{|c|c|c|c|}
\hline & $\begin{array}{l}\text { Would cause no } \\
\text { harm at all }\end{array}$ & $\begin{array}{l}\text { Moderate } \\
\text { harm }\end{array}$ & $\begin{array}{l}\text { Would cause } \\
\text { extreme harm }\end{array}$ \\
\hline Your health: & 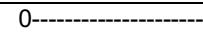 & 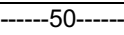 & 100 1------------- \\
\hline $\begin{array}{l}\text { The health of others in } \\
\text { this area: }\end{array}$ & 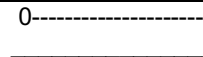 & 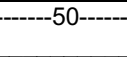 & -------100 \\
\hline
\end{tabular}

14. If a heat wave were to occur in your local area (where you live), how much, if at all, do you think it would harm the following?

Provide your best estimate by placing an X mark on the scale below for each item.

\begin{tabular}{|c|c|c|}
\hline & $\begin{array}{lc}\text { Would cause no } & \text { Moderate } \\
\text { harm at all } & \text { harm }\end{array}$ & $\begin{array}{l}\text { Would cause } \\
\text { extreme harm }\end{array}$ \\
\hline Your health: & 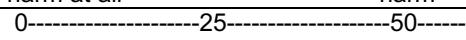 & - \\
\hline The health of others in & 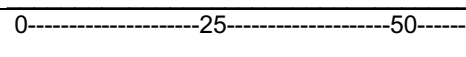 & -100 \\
\hline
\end{tabular}

15. How worried, if at all, are you about the effects of heat waves on the following? Provide your best estimate by placing an X mark on the scale below for each item.

\begin{tabular}{|c|c|c|c|c|c|}
\hline & $\begin{array}{l}\text { Not worried } \\
\text { at all }\end{array}$ & $\begin{array}{c}\text { A little } \\
\text { worried }\end{array}$ & $\begin{array}{l}\text { Moderately } \\
\text { worried }\end{array}$ & $\begin{array}{c}\text { Very } \\
\text { worried }\end{array}$ & $\begin{array}{r}\text { Extremely } \\
\text { worried }\end{array}$ \\
\hline Your health: & \multicolumn{5}{|c|}{ 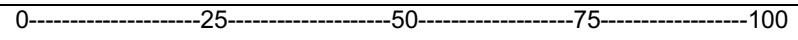 } \\
\hline $\begin{array}{l}\text { The health of others in } \\
\text { your community: }\end{array}$ & |0----------- & ----25----. & -------50------ & -----75---- & "-------100 \\
\hline
\end{tabular}

16. How often have you experienced the following effects of heat in the past year?
a. Decreased productivity at work (circle one): Never
Rarely Occasionally Often
b. Personal discomfort (circle one):
Never
Rarely
Occasionally Often

c. Heat-related illness, such as heat exhaustion or heat stroke (circle one):
Never
Rarely
Occasionally
Often

17. Have you received or heard information about what to do during hot weather since entering the area? (circle one)

Yes

No

Continue to next page

2 of 3 
18. Did you check the weather conditions for today? (circle one)

Yes

No

19. How many people are in your group?

people

How many people in your group are:

less than 5 years old: 5-18 years old: 19-64 years old: older than 65 :

20. What is your age? (circle one)
18-24 years old
25-34 years old
35-44 years old
45-54 years old
55-64 years old
65-74 years old
75 years or older

21. Are you... (circle one)
Male
Female
Non-binary/ third gender
Prefer to self-describe:

22. Are you of Spanish, Hispanic, or Latino descent? (circle one)

Yes

No

23. Which race or ethnic background best describes you?

African American or Black

Asian

American Indian or Alaska Native

Native Hawaiian or Pacific Islander

White or Caucasian

Other:

24. What is the highest level of school you have completed?

Less than high school

Some high school, no diploma

High school graduate - high school diploma or the equivalent (GED)

Some college, no degree

Associate degree

Bachelor's degree

Master's, professional, or doctorate degree

Thank you for completing this survey! 


\section{APPENDIX C}

\section{PHOTOS FROM TRAILHEAD}

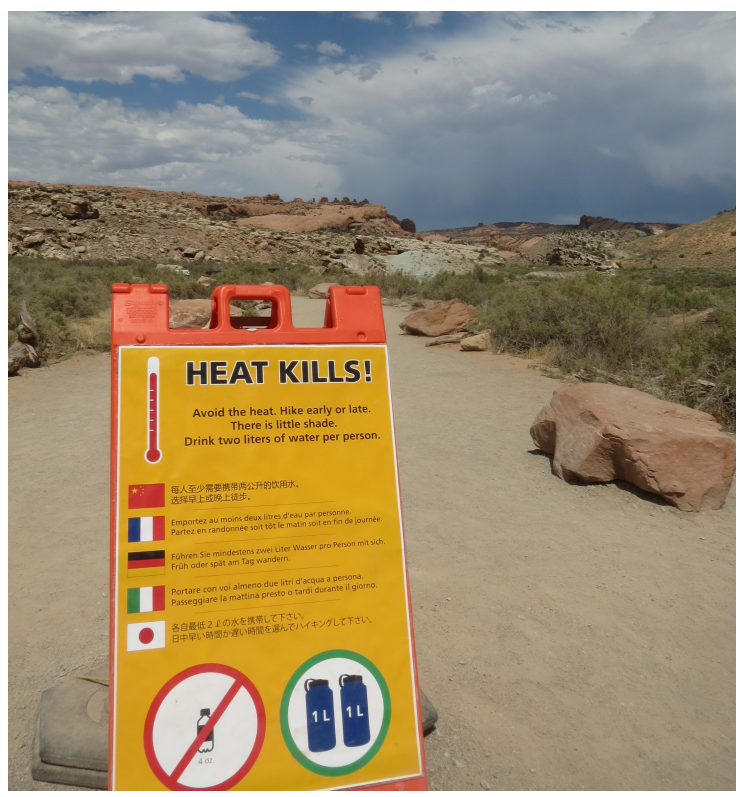

Figure 3. Warning sign. Warning sign placed at the start of Delicate Arch trailhead. Sign reads: "Heat Kills! Avoid the heat. Hike early or late. There is little shade. Drink two liters of water per person." Message is written in English, Mandarin Chinese, French, German, Italian, and Japanese. Notably missing is Spanish.

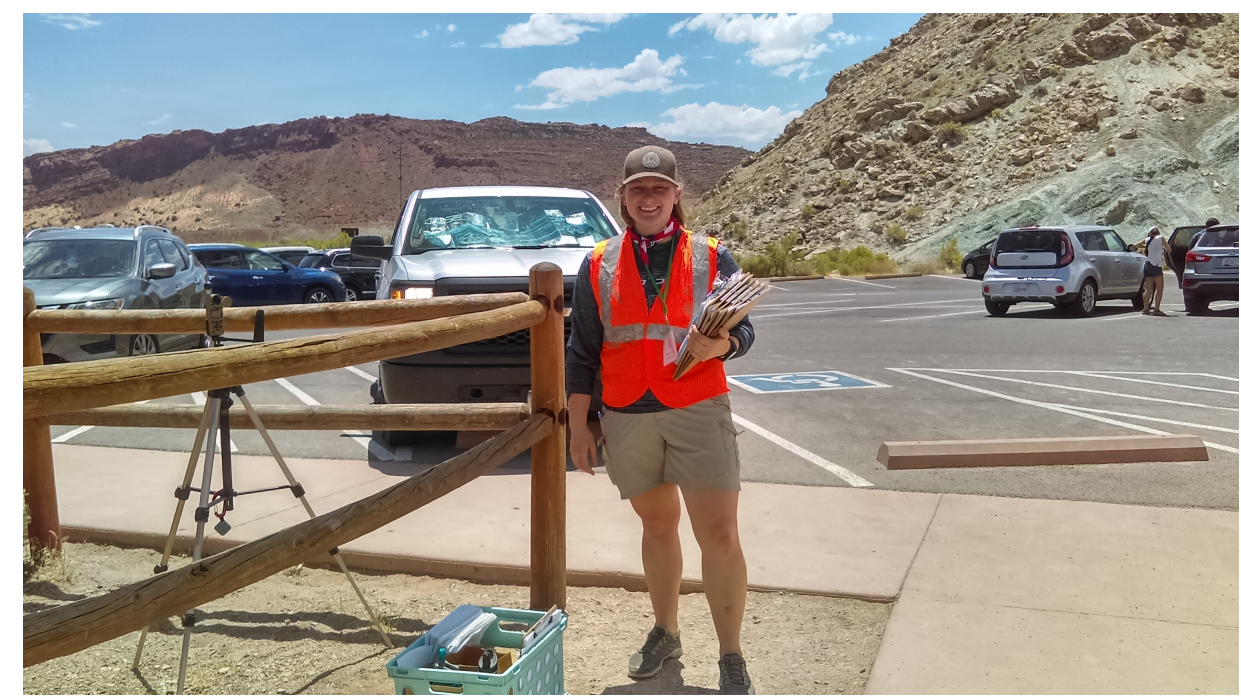

Figure 4. Survey location. Myself at the trailhead for Delicate Arch trail. To the left is the Kestrel 5400 Heat Stress Tracker instrument. I am looking in the direction of the trail and warning sign. 


\section{APPENDIX D}

\section{LINEAR MIXED-EFFECT MODELS}

Thermal Perception (temperature estimate)

Model $1 \quad$ Model 2

Model 3

Model 4

Model 5

Predictors Estimates Conf. Int Estimates Conf. Int Estimates Conf. Int Estimates Conf. Int Estimates Conf. Int

\begin{tabular}{|c|c|c|c|c|c|c|c|c|c|c|}
\hline Intercept & 2.38 & $\begin{array}{l}-0.50- \\
5.25\end{array}$ & 2.51 & $\begin{array}{c}-0.54- \\
5.56\end{array}$ & 3.11 & $\begin{array}{c}-0.24- \\
6.45\end{array}$ & 2.58 & $\begin{array}{c}-0.56- \\
5.71\end{array}$ & 3.19 & $\begin{array}{c}-0.26- \\
6.63\end{array}$ \\
\hline $\begin{array}{l}\text { Temperature } \\
\text { (C) }\end{array}$ & $\begin{array}{l}0.76 \\
* * *\end{array}$ & $\begin{array}{c}0.65- \\
0.88\end{array}$ & $\begin{array}{l}0.77 \\
* * *\end{array}$ & $\begin{array}{c}0.66- \\
0.88\end{array}$ & $\begin{array}{l}0.76 \\
* * *\end{array}$ & $\begin{array}{c}0.65- \\
0.87\end{array}$ & $\begin{array}{c}0.76 \\
* * *\end{array}$ & $\begin{array}{c}0.64- \\
0.87\end{array}$ & $\begin{array}{l}0.75 \\
* * *\end{array}$ & $\begin{array}{c}0.64- \\
0.87\end{array}$ \\
\hline $\begin{array}{l}\text { Dew Point } \\
\text { (C) }\end{array}$ & $0.07^{*}$ & $\begin{array}{c}0.01- \\
0.12\end{array}$ & $0.07^{*}$ & $\begin{array}{c}0.02- \\
0.13\end{array}$ & $0.08^{* *}$ & $\begin{array}{c}0.02- \\
0.13\end{array}$ & $0.07^{*}$ & $\begin{array}{c}0.02- \\
0.13\end{array}$ & $0.08^{* *}$ & $\begin{array}{c}0.02- \\
0.13\end{array}$ \\
\hline $\begin{array}{l}\text { Globe Temp } \\
\text { (C) }\end{array}$ & $0.11^{* *}$ & $\begin{array}{c}0.04- \\
0.18\end{array}$ & $0.11^{* *}$ & $\begin{array}{c}0.04- \\
0.19\end{array}$ & $0.12^{* *}$ & $\begin{array}{c}0.05- \\
0.19\end{array}$ & $0.12^{* *}$ & $\begin{array}{c}0.04- \\
0.19\end{array}$ & $0.12^{* *}$ & $\begin{array}{c}0.05- \\
0.20\end{array}$ \\
\hline $\begin{array}{l}\text { United } \\
\text { States (a) }\end{array}$ & & & & & -0.08 & $\begin{array}{l}-1.15- \\
0.99\end{array}$ & & & -0.06 & $\begin{array}{c}-1.14- \\
1.02\end{array}$ \\
\hline Utah (a) & & & & & -0.82 & $\begin{array}{c}-2.14- \\
0.50\end{array}$ & & & -0.71 & $\begin{array}{c}-2.12- \\
0.69\end{array}$ \\
\hline $\begin{array}{l}\text { Western } \\
\text { States (a) }\end{array}$ & & & & & -0.63 & $\begin{array}{l}-1.77- \\
0.52\end{array}$ & & & -0.61 & $\begin{array}{c}-1.83- \\
0.60\end{array}$ \\
\hline $\begin{array}{l}\text { Continental } \\
\text { (b) }\end{array}$ & & & & & & & 0.15 & $\begin{array}{c}-0.94- \\
1.25\end{array}$ & -0.14 & $\begin{array}{c}-1.37- \\
1.10\end{array}$ \\
\hline $\begin{array}{l}\text { Temperate } \\
\text { (b) }\end{array}$ & & & & & & & 0.41 & $\begin{array}{c}-0.63- \\
1.46\end{array}$ & 0.04 & $\begin{array}{l}-1.12- \\
1.20\end{array}$ \\
\hline Tropical (b) & & & & & & & 1.36 & $\begin{array}{c}-1.54- \\
4.26\end{array}$ & 0.84 & $\begin{array}{c}-2.14- \\
3.83\end{array}$ \\
\hline \multicolumn{11}{|c|}{ Random Effects } \\
\hline$\sigma^{2}$ & 9.64 & & 9.46 & & 9.43 & & 9.49 & & 9.50 & \\
\hline \multirow[t]{6}{*}{$\tau_{00}$} & \multirow[t]{6}{*}{0.21 Trail } & & \multicolumn{2}{|c|}{0.11 Q20_age } & \multicolumn{2}{|c|}{0.15 Q20_age } & \multicolumn{2}{|c|}{0.13 Q20_age } & \multicolumn{2}{|c|}{0.16 Q20_age } \\
\hline & & & \multicolumn{2}{|c|}{0.00 Q24_educ_bin } & \multicolumn{2}{|c|}{0.00 Q24_educ_bin } & \multicolumn{2}{|c|}{0.00 Q24_educ_bin } & \multicolumn{2}{|c|}{0.00 Q24_educ_bin } \\
\hline & & & \multicolumn{2}{|c|}{0.05 Q21_gender } & \multicolumn{2}{|c|}{0.06 Q21_gender } & \multicolumn{2}{|c|}{0.07 Q21_gender } & \multicolumn{2}{|c|}{0.07 Q21_gender } \\
\hline & & & \multicolumn{2}{|c|}{0.00 Q23_race_bin } & \multicolumn{2}{|c|}{0.00 Q23_race_bin } & \multicolumn{2}{|c|}{0.00 Q23_race_bin } & \multicolumn{2}{|c|}{0.00 Q23_race_bin } \\
\hline & & & \multicolumn{2}{|c|}{0.64 Q22_hispanic } & \multicolumn{2}{|c|}{1.04 Q22_hispanic } & \multicolumn{2}{|c|}{0.70 Q22_hispanic } & \multicolumn{2}{|c|}{0.91 Q22_hispanic } \\
\hline & & & \multicolumn{2}{|c|}{$0.16_{\text {Trail }}$} & \multicolumn{2}{|c|}{$0.10_{\text {Trail }}$} & \multicolumn{2}{|c|}{$0.16_{\text {Trail }}$} & \multicolumn{2}{|c|}{$0.10_{\text {Trail }}$} \\
\hline \multirow{2}{*}{$\begin{array}{l}\text { Observations } \\
\text { AIC }\end{array}$} & 342 & & \multicolumn{2}{|l|}{342} & \multicolumn{2}{|l|}{342} & \multicolumn{2}{|l|}{342} & \multicolumn{2}{|l|}{342} \\
\hline & \multicolumn{2}{|l|}{1771.474} & \multicolumn{2}{|c|}{1779.418} & 1781.09 & & 1781.12 & & 1783.25 & \\
\hline
\end{tabular}


Thermal Difference (absolute difference between temperature and temperature estimates)

\section{Model 1 \\ Model 2 \\ Model 3 \\ Model 4 \\ Model 5}

Predictors Estimates Conf. Int Estimates Conf. Int Estimates Conf. Int Estimates Conf. Int Estimates Conf. Int

\begin{tabular}{|c|c|c|c|c|c|c|c|c|c|c|}
\hline Intercept & $2.69^{* *}$ & $\begin{array}{c}0.87- \\
4.52\end{array}$ & $2.92^{* *}$ & $\begin{array}{c}1.03- \\
4.81\end{array}$ & $3.20^{* *}$ & $\begin{array}{c}1.13- \\
5.27\end{array}$ & $2.99^{* *}$ & $\begin{array}{c}1.03- \\
4.95\end{array}$ & $2.92^{* *}$ & $\begin{array}{c}0.75- \\
5.09\end{array}$ \\
\hline $\begin{array}{l}\text { Temperature } \\
\text { (C) }\end{array}$ & 0.02 & $\begin{array}{c}-0.06- \\
0.10\end{array}$ & 0.03 & $\begin{array}{c}-0.05- \\
0.11\end{array}$ & 0.03 & $\begin{array}{c}-0.05- \\
0.11\end{array}$ & 0.01 & $\begin{array}{c}-0.07- \\
0.09\end{array}$ & 0.02 & $\begin{array}{c}-0.06- \\
0.10\end{array}$ \\
\hline $\begin{array}{l}\text { Dew Point } \\
\text { (C) }\end{array}$ & -0.01 & $\begin{array}{c}-0.04- \\
0.03\end{array}$ & -0.01 & $\begin{array}{c}-0.04- \\
0.03\end{array}$ & -0.01 & $\begin{array}{c}-0.04- \\
0.03\end{array}$ & -0.01 & $\begin{array}{c}-0.04- \\
0.03\end{array}$ & -0.01 & $\begin{array}{c}-0.04- \\
0.03\end{array}$ \\
\hline $\begin{array}{l}\text { Globe Temp } \\
\text { (C) }\end{array}$ & -0.02 & $\begin{array}{c}-0.07- \\
0.03\end{array}$ & -0.03 & $\begin{array}{c}-0.08- \\
0.02\end{array}$ & -0.03 & $\begin{array}{c}-0.08- \\
0.02\end{array}$ & -0.02 & $\begin{array}{c}-0.08- \\
0.03\end{array}$ & -0.03 & $\begin{array}{c}-0.08- \\
0.03\end{array}$ \\
\hline $\begin{array}{l}\text { United } \\
\text { States (a) }\end{array}$ & & & & & -0.56 & $\begin{array}{c}-1.31- \\
0.20\end{array}$ & & & -0.52 & $\begin{array}{c}-1.28- \\
0.25\end{array}$ \\
\hline Utah (a) & & & & & -0.23 & $\begin{array}{c}-1.16- \\
0.70\end{array}$ & & & -0.05 & $\begin{array}{c}-1.03- \\
0.94\end{array}$ \\
\hline $\begin{array}{l}\text { Western } \\
\text { States (a) }\end{array}$ & & & & & -0.21 & $\begin{array}{c}-1.02- \\
0.61\end{array}$ & & & 0.02 & $\begin{array}{c}-0.84- \\
0.88\end{array}$ \\
\hline $\begin{array}{l}\text { Continental } \\
\text { (b) }\end{array}$ & & & & & & & 0.13 & $\begin{array}{c}-0.64- \\
0.89\end{array}$ & 0.39 & $\begin{array}{c}-0.47- \\
1.25\end{array}$ \\
\hline $\begin{array}{l}\text { Temperate } \\
\text { (b) }\end{array}$ & & & & & & & 0.33 & $\begin{array}{c}-0.40- \\
1.07\end{array}$ & 0.58 & $\begin{array}{c}-0.23- \\
1.39\end{array}$ \\
\hline Tropical (b) & & & & & & & 1.58 & $\begin{array}{c}-0.46- \\
3.61\end{array}$ & 1.96 & $\begin{array}{c}-0.14- \\
4.05\end{array}$ \\
\hline
\end{tabular}

\section{Random Effects}

\begin{tabular}{llllll}
$\sigma^{2}$ & 4.79 & 4.74 & 4.74 & 4.74 & 4.72 \\
$\tau_{00}$ & 0.00 Trail & 0.00 Q20_age & 0.00 Q20_age & 0.00 Q20_age & 0.00 Q20_age \\
& & 0.08 Q24_educ_bin & 0.07 Q24_educ_bin & 0.11 Q24_educ_bin & 0.09 Q24_educ_bin \\
& & 0.00 Q21_gender & 0.00 Q21_gender & 0.00 Q21_gender & 0.00 Q21_gender \\
& & 0.04 Q23_race_bin & 0.03 Q23_race_bin & 0.04 Q23_race_bin & 0.03 Q23_race_bin \\
& & 0.00 Q22_hispanic & 0.00 Q22_hispanic & 0.00 Q22_hispanic & 0.00 Q22_hispanic \\
& & 0.00 Trail & 0.00 Trail & 0.00 Trail & 0.00 Trail \\
\hline Observations & 342 & 342 & 342 & 342 & 342 \\
AIC & 1533.824 & 1542.314 & 1546.440 & 1544.636 & 1547.123 \\
\hline \hline
\end{tabular}


Risk Perception

\section{Model 1}

Model 2

Model 3

Model 4

Predictors Estimates Conf. Int Estimates Conf. Int Estimates Conf. Int Estimates Conf. Int

Intercept

46.73

39.10

54.35

46.93

$38.19-$

54.95

34.21 - $55.67 \quad 34.69-$

United States (a)

Utah (a)

$$
-2.41
$$

9.22

$* * *$

75.68

$* * *$

76.64

Western States (a)

2.54

4.40

$-2.56$

$-9.41-$

4.29

$-2.59 \quad-9.45-$

$-5.90-$

2.45

$-6.08-$

2.32

4.27

10.97

10.97

$-6.22-$

$0.47 \quad-6.76-$

0.10

$-7.22-$

7.42

$-0.01 \quad-7.35-$

7.71

$-0.23$

$-0.76-$

$-0.26$

7.34

Temperature (C)

Temperature Difference

(absolute)

0.29

$-0.79-$

$-0.16 \quad-0.84-$

0.52

\section{Random Effects}

\begin{tabular}{lllll}
$\sigma^{2}$ & 370.72 & 366.88 & 369.78 & 370.85 \\
$\tau_{00}$ & 1.23 Q20_age & 1.87 Q20_age & 2.62 Q20_age & 2.20 Q20_age \\
& 0.00 Q24_educ_bin & 0.00 Q24_educ_bin & 0.00 Q24_educ_bin & 0.00 Q24_educ_bin \\
& 0.00 Q21_gender & 0.00 Q21_gender & 0.00 Q21_gender & 0.00 Q21_gender \\
& 25.53 Q23_race_bin & 14.86 Q23_race_bin & 24.49 Q23_race_bin & $\begin{array}{l}24.30 \\
\text { Q23_race_bin }\end{array}$ \\
& 3.91 Trail & 4.10 Trail & 10.01 Trail & 10.99 Trail \\
& 0.00 Q22_hispanic & 0.00 Q22_hispanic & 0.00 Q22_hispanic & 0.00 Q22_hispanic \\
\hline Observations & 328 & 328 & 328 & 328 \\
AIC & 2888.227 & 2895.868 & 2881.476 & 2883.541 \\
\hline \hline
\end{tabular}




\section{APPENDIX D}

\section{GENERALIZED LINEAR MIXED-EFFECT MODELS}

Check the weather

\begin{tabular}{|c|c|c|c|c|c|c|c|c|c|c|}
\hline \multirow[b]{2}{*}{ Predictors } & \multicolumn{2}{|c|}{ Model 1} & \multicolumn{2}{|c|}{ Model 2} & \multicolumn{2}{|c|}{ Model 3} & \multicolumn{2}{|c|}{ Model 4} & \multicolumn{2}{|c|}{ Model 5} \\
\hline & $\begin{array}{l}\text { Odds } \\
\text { Ratios }\end{array}$ & Conf. Int & $\begin{array}{l}\text { Odds } \\
\text { Ratios }\end{array}$ & Conf. Int & $\begin{array}{l}\text { Odds } \\
\text { Ratios }\end{array}$ & Conf. Int & $\begin{array}{l}\text { Odds } \\
\text { Ratios }\end{array}$ & Conf. Int & $\begin{array}{l}\text { Odds } \\
\text { Ratios }\end{array}$ & Conf. Int \\
\hline Intercept & $\begin{array}{l}6.76 \\
* * *\end{array}$ & $\begin{array}{r}2.81- \\
16.25\end{array}$ & $\begin{array}{c}7.36 \\
* *\end{array}$ & $\begin{array}{l}2.16- \\
25.02\end{array}$ & 7.30 & $\begin{array}{l}0.41- \\
129.84\end{array}$ & 7.74 & $\begin{array}{l}0.42- \\
141.04\end{array}$ & 2.53 & $\begin{array}{c}0.11- \\
59.04\end{array}$ \\
\hline United States (a) & & & 0.86 & $\begin{array}{c}0.30- \\
2.50\end{array}$ & 0.86 & $\begin{array}{c}0.30- \\
2.50\end{array}$ & 0.85 & $\begin{array}{c}0.29- \\
2.48\end{array}$ & 0.89 & $\begin{array}{c}0.30- \\
2.61\end{array}$ \\
\hline Utah (a) & & & 0.71 & $\begin{array}{c}0.21- \\
2.45\end{array}$ & 0.71 & $\begin{array}{c}0.21- \\
2.47\end{array}$ & 0.71 & $\begin{array}{c}0.21- \\
2.48\end{array}$ & 0.73 & $\begin{array}{c}0.21- \\
2.58\end{array}$ \\
\hline Western States (a) & & & 1.16 & $\begin{array}{c}0.36- \\
3.72\end{array}$ & 1.16 & $\begin{array}{c}0.36- \\
3.74\end{array}$ & 1.16 & $\begin{array}{c}0.36- \\
3.73\end{array}$ & 1.20 & $\begin{array}{c}0.37- \\
3.87\end{array}$ \\
\hline Temperature (C) & & & & & 1.00 & $\begin{array}{c}0.93- \\
1.08\end{array}$ & 1.00 & $\begin{array}{c}0.93- \\
1.08\end{array}$ & 1.01 & $\begin{array}{c}0.93- \\
1.09\end{array}$ \\
\hline $\begin{array}{l}\text { Temperature } \\
\text { Difference } \\
\text { (absolute) }\end{array}$ & & & & & & & 0.98 & $\begin{array}{c}0.84- \\
1.13\end{array}$ & 0.96 & $\begin{array}{c}0.82- \\
1.11\end{array}$ \\
\hline Risk Perception & & & & & & & & & $\begin{array}{c}1.02 \\
*\end{array}$ & $\begin{array}{c}1.00- \\
1.04\end{array}$ \\
\hline \multicolumn{11}{|l|}{ Random Effects } \\
\hline$\sigma^{2}$ & 3.29 & & 3.29 & & 3.29 & & 3.29 & & 3.29 & \\
\hline \multirow[t]{6}{*}{$\tau_{00}$} & \multicolumn{2}{|c|}{0.16 Q20_age } & \multicolumn{2}{|c|}{0.16 Q20_age } & \multicolumn{2}{|c|}{0.16 Q20_age } & \multicolumn{2}{|c|}{0.16 Q20_age } & \multicolumn{2}{|c|}{0.16 Q20_age } \\
\hline & \multicolumn{2}{|c|}{$\begin{array}{l}0.15 \\
\text { Q24_educ_bin }\end{array}$} & \multicolumn{2}{|c|}{$\begin{array}{l}0.13 \\
\text { Q24_educ_bin }\end{array}$} & \multicolumn{2}{|c|}{$\begin{array}{l}0.13 \\
\text { Q24_educ_bin }\end{array}$} & \multicolumn{2}{|c|}{$\begin{array}{l}0.13 \\
\text { Q24_educ_bin }\end{array}$} & \multicolumn{2}{|c|}{$\begin{array}{l}0.16 \\
\text { Q24_educ_bin }\end{array}$} \\
\hline & \multicolumn{2}{|c|}{$\begin{array}{l}0.14 \\
\text { Q21_gender }\end{array}$} & \multicolumn{2}{|c|}{$\begin{array}{l}0.12 \\
\text { Q21_gender }\end{array}$} & \multicolumn{2}{|c|}{0.12 Q21_gender } & \multicolumn{2}{|c|}{0.12 Q21_gender } & \multicolumn{2}{|c|}{0.18 Q21_gender } \\
\hline & \multicolumn{2}{|c|}{$\begin{array}{l}0.00 \\
\text { Q23_race_bin }\end{array}$} & \multicolumn{2}{|c|}{$\begin{array}{l}0.00 \\
\text { Q23_race_bin }\end{array}$} & \multicolumn{2}{|c|}{$\begin{array}{l}0.00 \\
\text { Q23_race_bin }\end{array}$} & \multicolumn{2}{|c|}{$\begin{array}{l}0.00 \\
\text { Q23_race_bin }\end{array}$} & 0.09 & ce_bin \\
\hline & \multicolumn{2}{|c|}{0.00 Trail } & \multicolumn{2}{|c|}{0.00 Trail } & \multicolumn{2}{|c|}{0.00 Trail } & \multicolumn{2}{|c|}{0.00 Trail } & \multicolumn{2}{|c|}{0.00 Trail } \\
\hline & \multicolumn{2}{|c|}{$\begin{array}{l}0.00 \\
\text { Q22_hispanic }\end{array}$} & $\begin{array}{l}0.00 \\
\text { Q22_his }\end{array}$ & spanic & $\begin{array}{l}0.00 \\
\text { Q22_hi }\end{array}$ & panic & $\begin{array}{l}0.00 \\
\text { Q22_his }\end{array}$ & panic & $\begin{array}{l}0.00 \\
\text { Q22_his }\end{array}$ & spanic \\
\hline Observations & 327 & & 327 & & 327 & & 327 & & 327 & \\
\hline AIC & 269.22 & & 274.26 & & 276.26 & & 278.16 & & 274.53 & \\
\hline
\end{tabular}


Carrying water (more than 1 liter)

\begin{tabular}{|c|c|c|c|c|c|c|c|c|c|c|}
\hline \multirow[b]{2}{*}{ Predictors } & \multicolumn{2}{|c|}{ Model 1} & \multicolumn{2}{|c|}{ Model 2} & \multicolumn{2}{|c|}{ Model 3} & \multicolumn{2}{|c|}{ Model 4} & \multicolumn{2}{|c|}{ Model 5} \\
\hline & $\begin{array}{l}\text { Odds } \\
\text { Ratios }\end{array}$ & $\begin{array}{c}\text { Conf. } \\
\text { Int }\end{array}$ & $\begin{array}{l}\text { Odds } \\
\text { Ratios }\end{array}$ & Conf. Int & $\begin{array}{l}\text { Odds } \\
\text { Ratios }\end{array}$ & Conf. Int & $\begin{array}{l}\text { Odds } \\
\text { Ratios }\end{array}$ & Conf. Int & $\begin{array}{l}\text { Odds } \\
\text { Ratios }\end{array}$ & Conf. Int \\
\hline Intercept & $\begin{array}{l}3.18 \\
* * *\end{array}$ & $\begin{array}{c}2.13- \\
4.77\end{array}$ & $\begin{array}{l}8.64 \\
* * *\end{array}$ & $\begin{array}{l}2.93- \\
25.46\end{array}$ & 4.43 & $\begin{array}{c}0.43- \\
45.20\end{array}$ & 3.89 & $\begin{array}{c}0.38- \\
39.87\end{array}$ & 4.17 & $\begin{array}{c}0.38- \\
45.97\end{array}$ \\
\hline United States (a) & & & 0.36 & $\begin{array}{c}0.12- \\
1.07\end{array}$ & 0.36 & $\begin{array}{c}0.12- \\
1.08\end{array}$ & 0.36 & $\begin{array}{c}0.12- \\
1.08\end{array}$ & 0.35 & $\begin{array}{c}0.12- \\
1.08\end{array}$ \\
\hline Utah (a) & & & $\begin{array}{l}0.27 \\
*\end{array}$ & $\begin{array}{c}0.08- \\
0.93\end{array}$ & $\begin{array}{l}0.28 \\
*\end{array}$ & $\begin{array}{c}0.08- \\
0.95\end{array}$ & $\begin{array}{c}0.29 \\
*\end{array}$ & $\begin{array}{c}0.08- \\
1.00\end{array}$ & 0.29 & $\begin{array}{c}0.08- \\
1.00\end{array}$ \\
\hline Western States (a) & & & 0.35 & $\begin{array}{c}0.11- \\
1.11\end{array}$ & 0.36 & $\begin{array}{c}0.12- \\
1.15\end{array}$ & 0.37 & $\begin{array}{c}0.12- \\
1.19\end{array}$ & 0.37 & $\begin{array}{c}0.12- \\
1.19\end{array}$ \\
\hline Temperature (C) & & & & & 1.02 & $\begin{array}{c}0.96- \\
1.08\end{array}$ & 1.03 & $\begin{array}{c}0.97- \\
1.09\end{array}$ & 1.03 & $\begin{array}{c}0.97- \\
1.09\end{array}$ \\
\hline $\begin{array}{l}\text { Temperature } \\
\text { Difference (absolute) }\end{array}$ & & & & & & & 1.09 & $\begin{array}{c}1.00- \\
1.18\end{array}$ & 1.09 & $\begin{array}{c}1.00- \\
1.18\end{array}$ \\
\hline Risk Perception & & & & & & & & & 1.00 & $\begin{array}{c}0.99- \\
1.01\end{array}$ \\
\hline \multicolumn{11}{|l|}{ Random Effects } \\
\hline$\sigma^{2}$ & 3.29 & & 3.29 & & 3.29 & & 3.29 & & 3.29 & \\
\hline \multirow[t]{6}{*}{$\tau_{00}$} & \multicolumn{2}{|c|}{0.07 Q20_age } & \multicolumn{2}{|c|}{0.08 Q20_age } & \multicolumn{2}{|c|}{0.07 Q20_age } & \multicolumn{2}{|c|}{0.08 Q20_age } & \multicolumn{2}{|c|}{0.08 Q20_age } \\
\hline & \multicolumn{2}{|c|}{$\begin{array}{l}0.00 \\
\text { Q24_educ_bin }\end{array}$} & \multicolumn{2}{|c|}{$\begin{array}{l}0.00 \\
\text { Q24_educ_bin }\end{array}$} & \multicolumn{2}{|c|}{$\begin{array}{l}0.00 \\
\text { Q24_educ_bin }\end{array}$} & \multicolumn{2}{|c|}{$\begin{array}{l}0.00 \\
\text { Q24_educ_bin }\end{array}$} & \multicolumn{2}{|c|}{$\begin{array}{l}0.00 \\
\text { Q24_educ_bin }\end{array}$} \\
\hline & \multicolumn{2}{|c|}{$\begin{array}{l}0.00 \\
\text { Q21_gender }\end{array}$} & \multicolumn{2}{|c|}{0.00 Q21_gender } & \multicolumn{2}{|c|}{$0.00 \mathrm{Q} 21 \_$gender } & \multicolumn{2}{|c|}{$0.00 \mathrm{Q} 21$ gender } & \multicolumn{2}{|c|}{$0.00 \mathrm{Q} 21$ _gender } \\
\hline & \multicolumn{2}{|c|}{$\begin{array}{l}0.00 \\
\text { Q23_race_bin }\end{array}$} & \multicolumn{2}{|c|}{$\begin{array}{l}0.00 \\
\text { Q23_race_bin }\end{array}$} & \multicolumn{2}{|c|}{0.00} & \multicolumn{2}{|c|}{0.00} & \multicolumn{2}{|c|}{0.00} \\
\hline & \multicolumn{2}{|c|}{0.02 Trail } & \multicolumn{2}{|c|}{0.01 Trail } & \multicolumn{2}{|c|}{0.00 Trail } & \multicolumn{2}{|c|}{0.00 Trail } & \multicolumn{2}{|c|}{0.00 Trail } \\
\hline & \multicolumn{2}{|c|}{0.00} & $\begin{array}{l}0.00 \\
\text { Q22_hi }\end{array}$ & panic & $\begin{array}{l}0.00 \\
\text { Q22_hi }\end{array}$ & panic & $\begin{array}{l}0.00 \\
\text { Q22_his }\end{array}$ & panic & $\begin{array}{l}0.00 \\
\text { Q22_his }\end{array}$ & panic \\
\hline Observations & 328 & & 328 & & 328 & & 328 & & 328 & \\
\hline AIC & 372.16 & & 372.77 & & 374.38 & & 372.615 & & 374.56 & \\
\hline
\end{tabular}


Carrying water (more than 2 liters)

\begin{tabular}{|c|c|c|c|c|c|c|c|c|c|c|}
\hline \multirow[b]{2}{*}{ Predictors } & \multicolumn{2}{|c|}{ Model 1} & \multicolumn{2}{|c|}{ Model 2} & \multicolumn{2}{|c|}{ Model 3} & \multicolumn{2}{|c|}{ Model 4} & \multicolumn{2}{|c|}{ Model 5} \\
\hline & $\begin{array}{l}\text { Odds } \\
\text { Ratios }\end{array}$ & Conf. Int & $\begin{array}{l}\text { Odds } \\
\text { Ratios }\end{array}$ & Conf. Int & $\begin{array}{l}\text { Odds } \\
\text { Ratios }\end{array}$ & Conf. Int & $\begin{array}{l}\text { Odds } \\
\text { Ratios }\end{array}$ & Conf. Int & $\begin{array}{l}\text { Odds } \\
\text { Ratios }\end{array}$ & Conf. Int \\
\hline Intercept & $\begin{array}{c}0.43 \\
* * *\end{array}$ & $\begin{array}{c}0.34- \\
0.55\end{array}$ & 0.52 & $\begin{array}{c}0.27- \\
1.02\end{array}$ & 0.47 & $\begin{array}{c}0.06- \\
3.55\end{array}$ & 0.38 & $\begin{array}{c}0.05- \\
2.97\end{array}$ & 0.28 & $\begin{array}{r}0.03- \\
2.38\end{array}$ \\
\hline United States (a) & & & 0.85 & $\begin{array}{c}0.40- \\
1.81\end{array}$ & 0.85 & $\begin{array}{c}0.40- \\
1.82\end{array}$ & 0.87 & $\begin{array}{c}0.41- \\
1.85\end{array}$ & 0.88 & $\begin{array}{r}0.41- \\
1.89\end{array}$ \\
\hline Utah (a) & & & 0.66 & $\begin{array}{c}0.25- \\
1.72\end{array}$ & 0.67 & $\begin{array}{c}0.25- \\
1.75\end{array}$ & 0.70 & $\begin{array}{r}0.27- \\
1.86\end{array}$ & 0.69 & $\begin{array}{c}0.26- \\
1.84\end{array}$ \\
\hline Western States (a) & & & 0.82 & $\begin{array}{c}0.37- \\
1.82\end{array}$ & 0.82 & $\begin{array}{c}0.36- \\
1.84\end{array}$ & 0.86 & $\begin{array}{c}0.38- \\
1.95\end{array}$ & 0.86 & $\begin{array}{c}0.38- \\
1.94\end{array}$ \\
\hline Temperature (C) & & & & & 1.00 & $\begin{array}{c}0.95- \\
1.06\end{array}$ & 1.01 & $\begin{array}{c}0.95- \\
1.07\end{array}$ & 1.01 & $\begin{array}{c}0.95- \\
1.07\end{array}$ \\
\hline $\begin{array}{l}\text { Temperature } \\
\text { Difference (absolute) }\end{array}$ & & & & & & & 1.08 & $\begin{array}{c}0.99- \\
1.16\end{array}$ & 1.08 & $\begin{array}{c}1.00- \\
1.16\end{array}$ \\
\hline Risk Perception & & & & & & & & & 1.01 & $\begin{array}{c}0.99- \\
1.02\end{array}$ \\
\hline \multicolumn{11}{|l|}{ Random Effects } \\
\hline$\sigma^{2}$ & 3.29 & & 3.29 & & 3.29 & & 3.29 & & 3.29 & \\
\hline \multirow[t]{6}{*}{$\tau_{00}$} & \multicolumn{2}{|c|}{0.00 Q20_age } & \multicolumn{2}{|c|}{0.00 Q20_age } & \multicolumn{2}{|c|}{0.00 Q20_age } & \multicolumn{2}{|c|}{0.00 Q20_age } & \multicolumn{2}{|c|}{0.00 Q20_age } \\
\hline & \multicolumn{2}{|c|}{$\begin{array}{l}0.00 \\
\text { Q24_educ_bin }\end{array}$} & \multicolumn{2}{|c|}{$\begin{array}{l}0.00 \\
\text { Q24_educ_bin }\end{array}$} & \multicolumn{2}{|c|}{$\begin{array}{l}0.00 \\
\text { Q24_educ_bin }\end{array}$} & \multicolumn{2}{|c|}{$\begin{array}{l}0.00 \\
\text { Q24_educ_bin }\end{array}$} & \multicolumn{2}{|c|}{$\begin{array}{l}0.00 \\
\text { Q24_educ_bin }\end{array}$} \\
\hline & \multicolumn{2}{|c|}{$0.00 \mathrm{Q} 21 \_$gender } & \multicolumn{2}{|c|}{$0.00 \mathrm{Q} 21 \_$gender } & \multicolumn{2}{|c|}{$0.00 \mathrm{Q} 21$ gender } & \multicolumn{2}{|c|}{0.00 Q21_gender } & \multicolumn{2}{|c|}{0.00 Q21_gender } \\
\hline & \multicolumn{2}{|c|}{$\begin{array}{l}0.00 \\
\text { Q23_race_bin }\end{array}$} & \multicolumn{2}{|c|}{$\begin{array}{l}0.00 \\
\text { Q23_race_bin }\end{array}$} & \multicolumn{2}{|c|}{$\begin{array}{l}0.00 \\
\text { Q23_race_bin }\end{array}$} & \multicolumn{2}{|c|}{$\begin{array}{l}0.00 \\
\text { Q23_race_bin }\end{array}$} & \multicolumn{2}{|c|}{0.00} \\
\hline & \multicolumn{2}{|c|}{0.00 Trail } & \multicolumn{2}{|c|}{0.00 Trail } & \multicolumn{2}{|c|}{0.00 Trail } & \multicolumn{2}{|c|}{0.00 Trail } & \multicolumn{2}{|c|}{0.00 Trail } \\
\hline & \multicolumn{2}{|c|}{$\begin{array}{l}0.00 \\
\text { Q22_hispanic }\end{array}$} & $\begin{array}{l}0.00 \\
\text { Q22_his }\end{array}$ & spanic & $\begin{array}{l}0.00 \\
\text { Q22_his }\end{array}$ & spanic & $\begin{array}{l}0.00 \\
\text { Q22_his }\end{array}$ & spanic & $\begin{array}{l}0.00 \\
\text { Q22_his }\end{array}$ & panic \\
\hline Observations & 328 & & 328 & & 328 & & 328 & & 328 & \\
\hline AIC & 415.73 & & 420.97 & & 422.97 & & 421.55 & & 422.32 & \\
\hline
\end{tabular}




\section{APPENDIX E}

\section{RANDOM EFFECTS ODDS RATIOS - RISKP}

Odds Ratios for random effects in the risk perception linear mixed-effect model, model 5, are listed here on the following pages in this order: Age, education, gender, Hispanic/non-Hispanic, race, and trailhead.

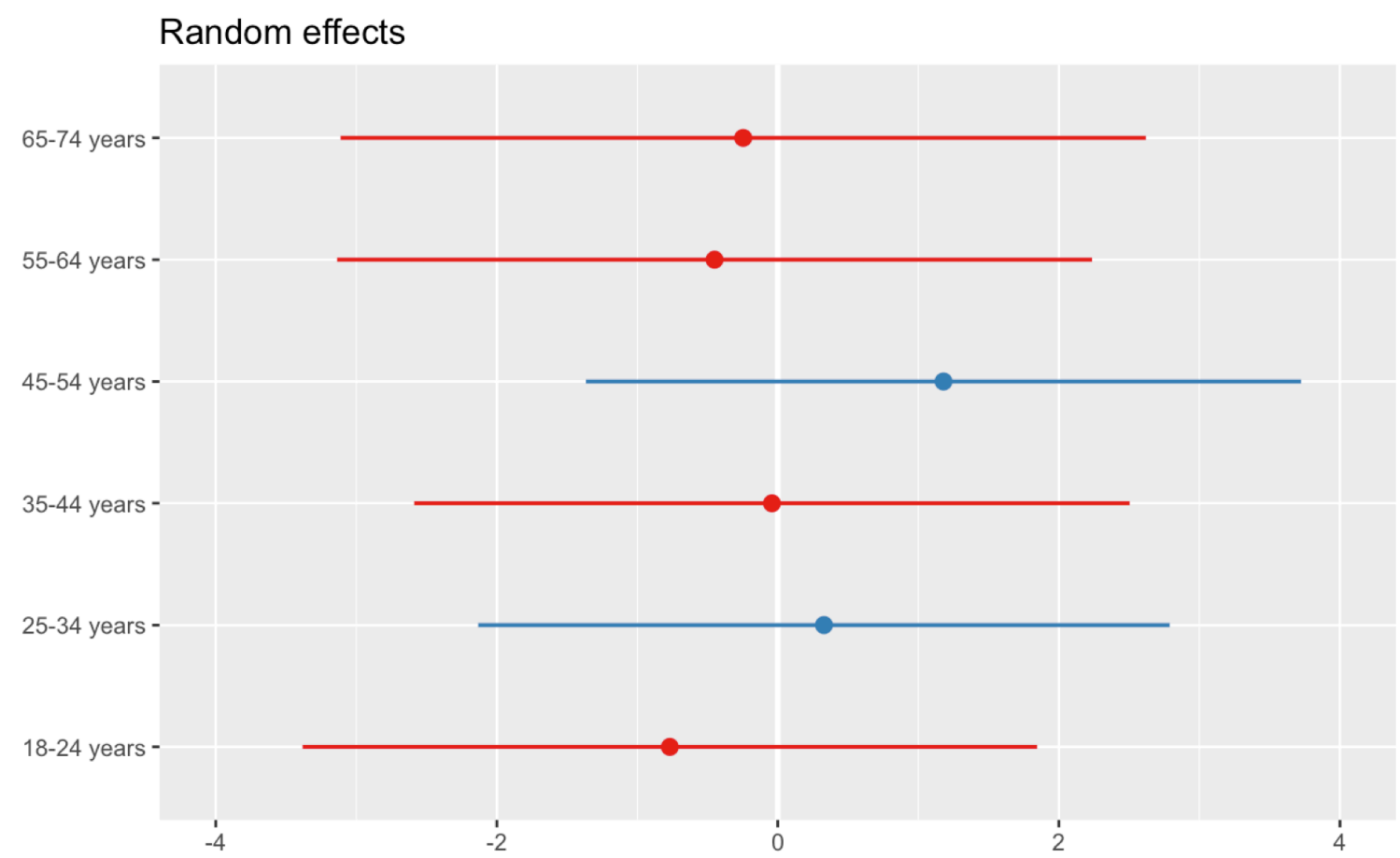



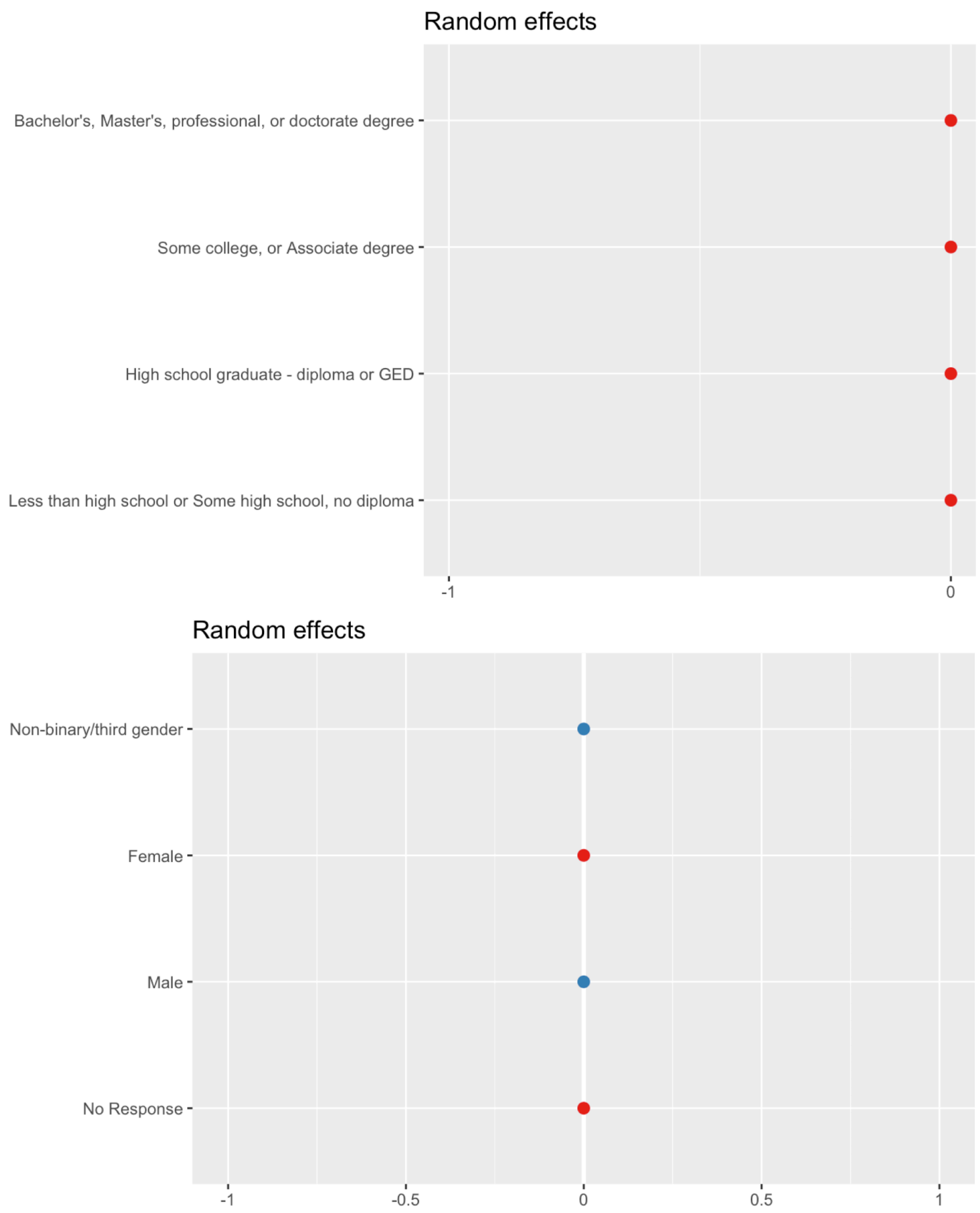

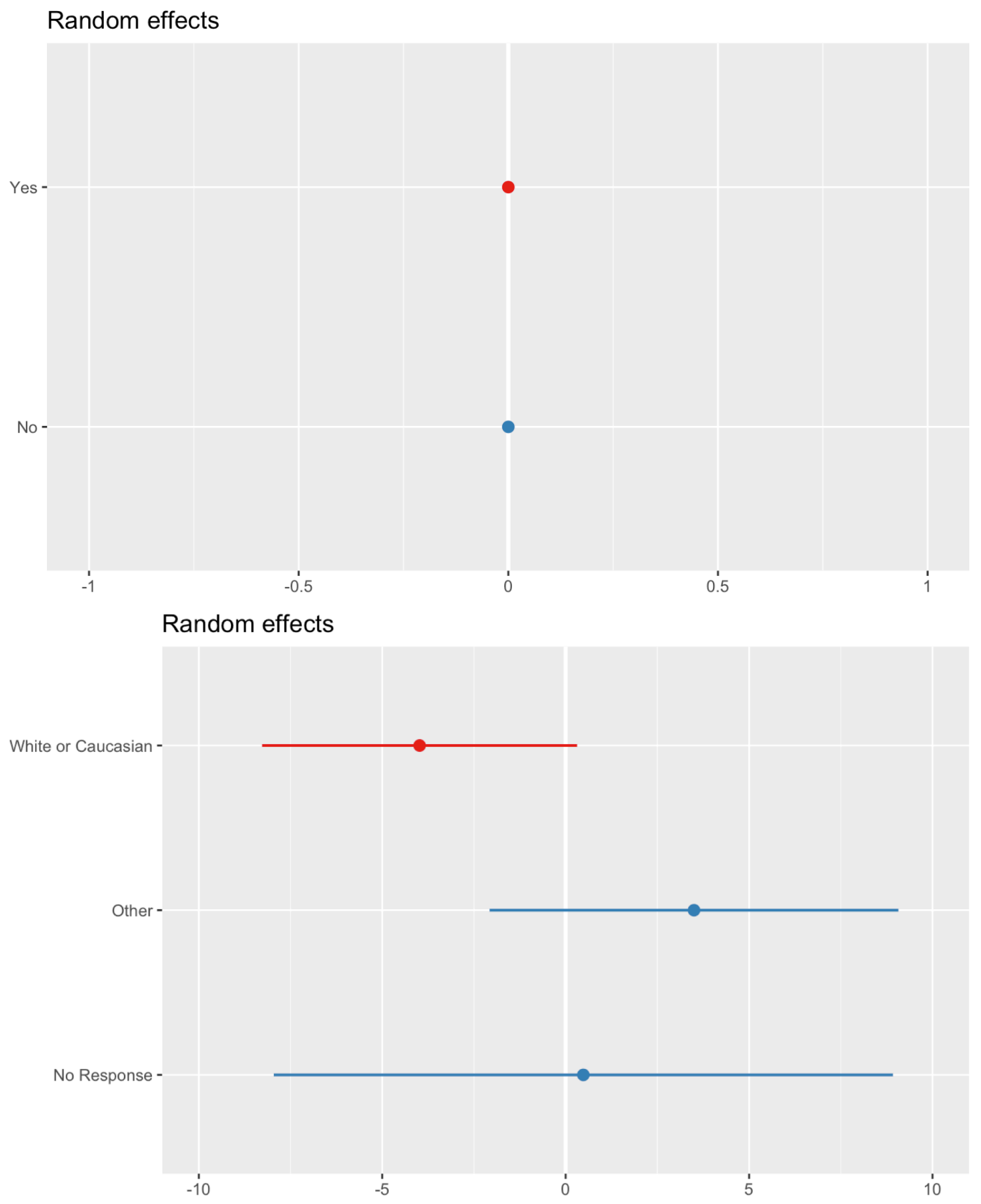


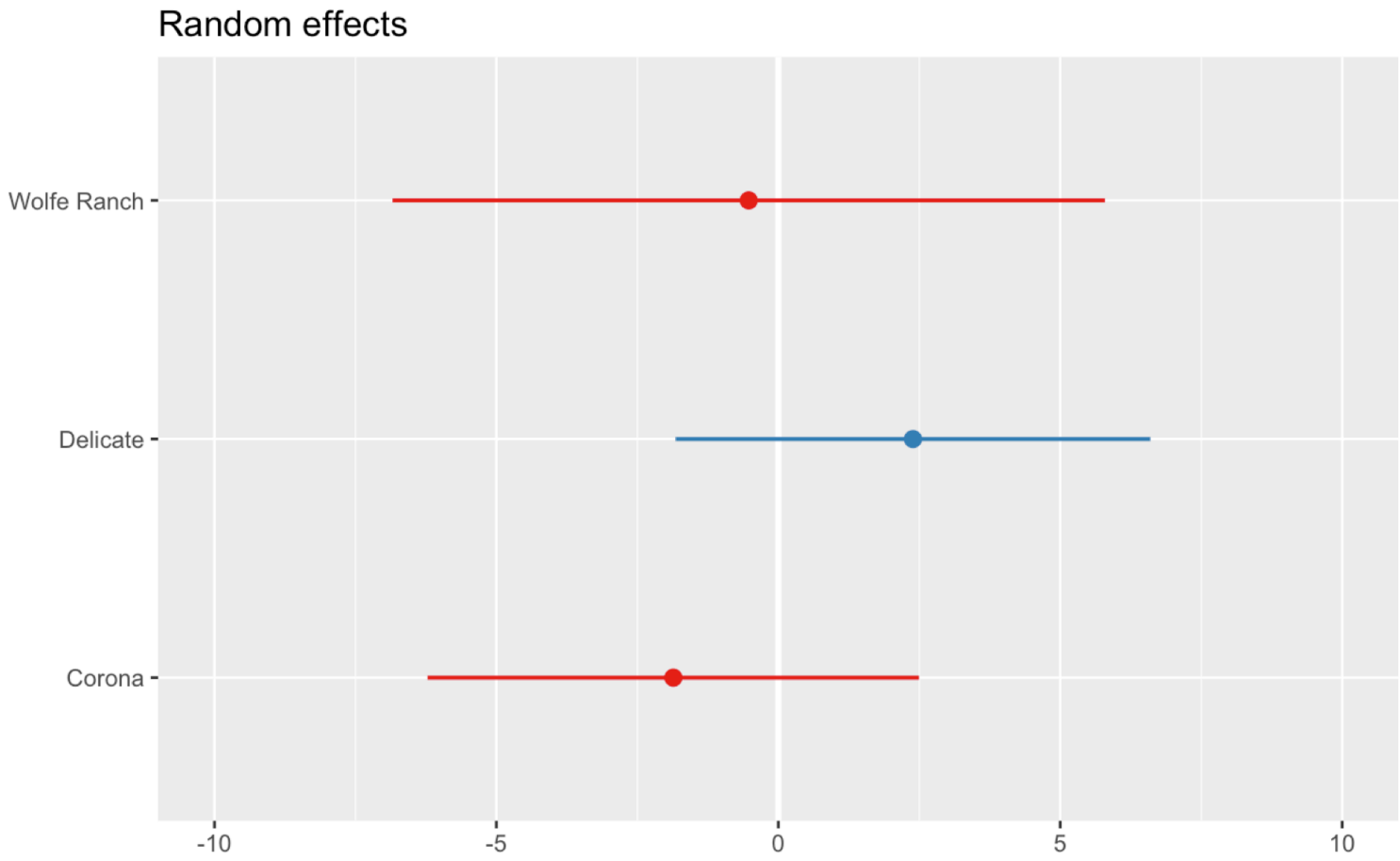




\section{APPENDIX F}

\section{RANDOM EFFECTS ODDS RATIOS - CHECK THE WEATHER}

Odds Ratios for random effects in the risk perception linear mixed-effect model, model 5, are listed here on the following pages in this order: Age, education, gender, Hispanic/non-Hispanic, race, and trailhead.

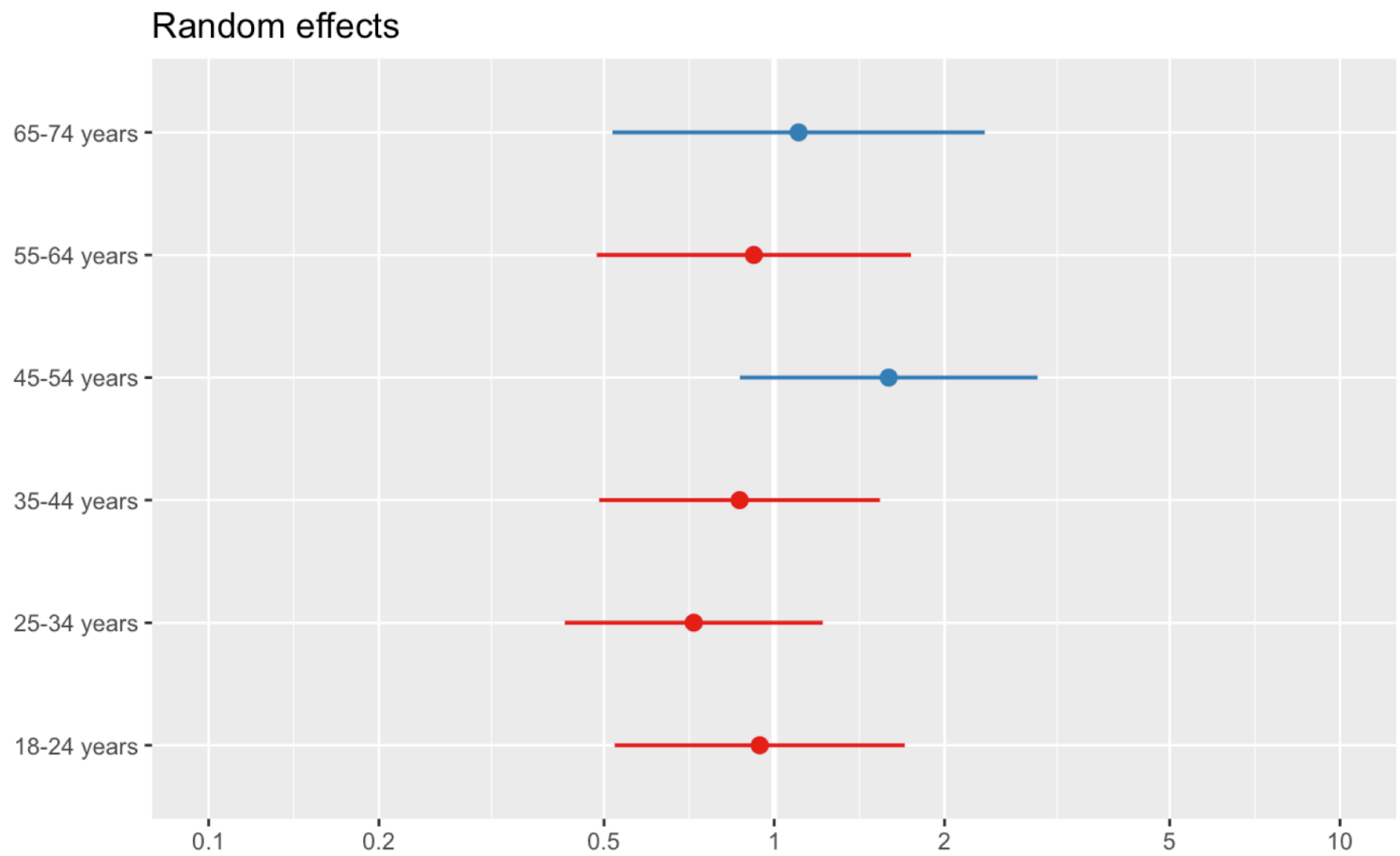



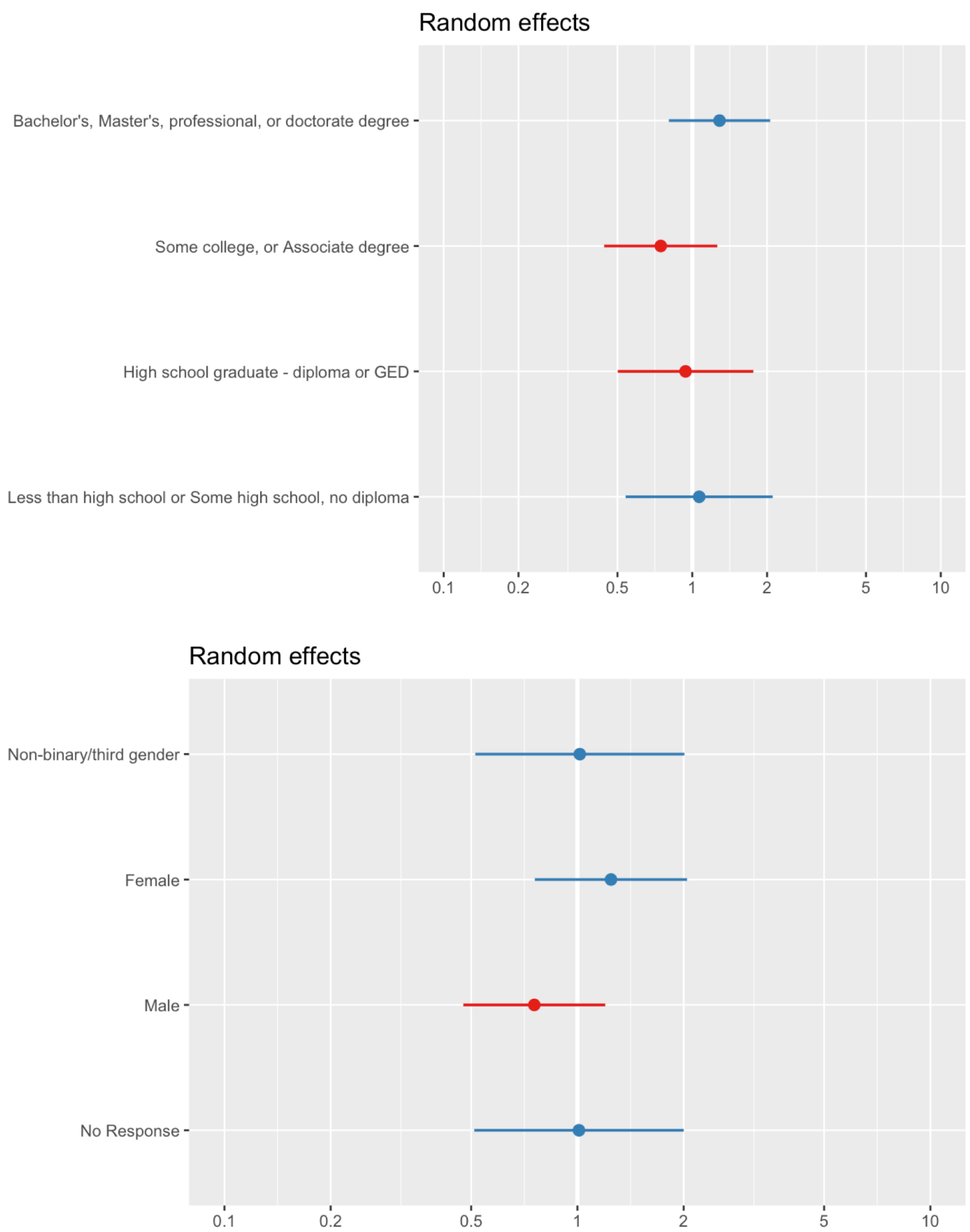

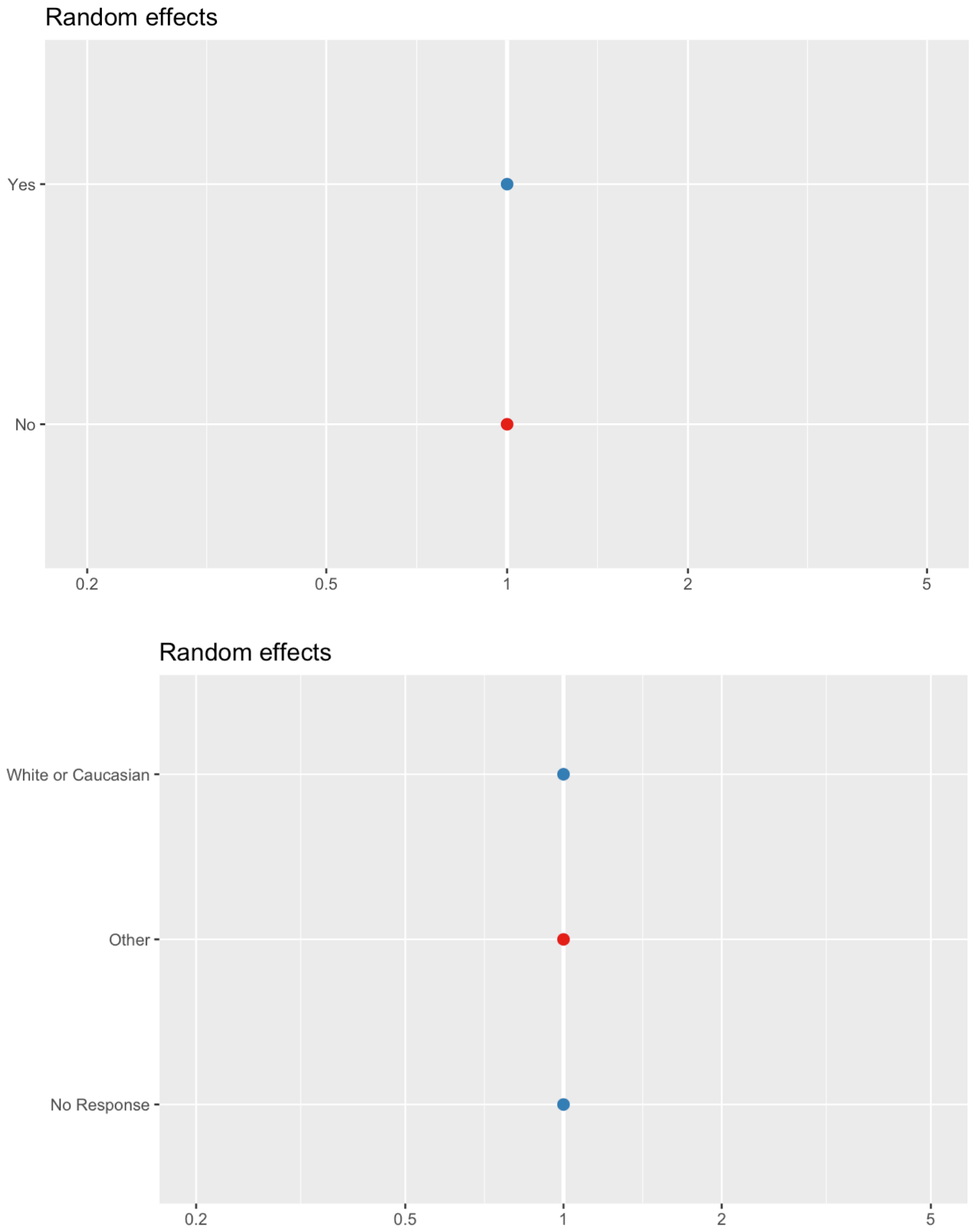


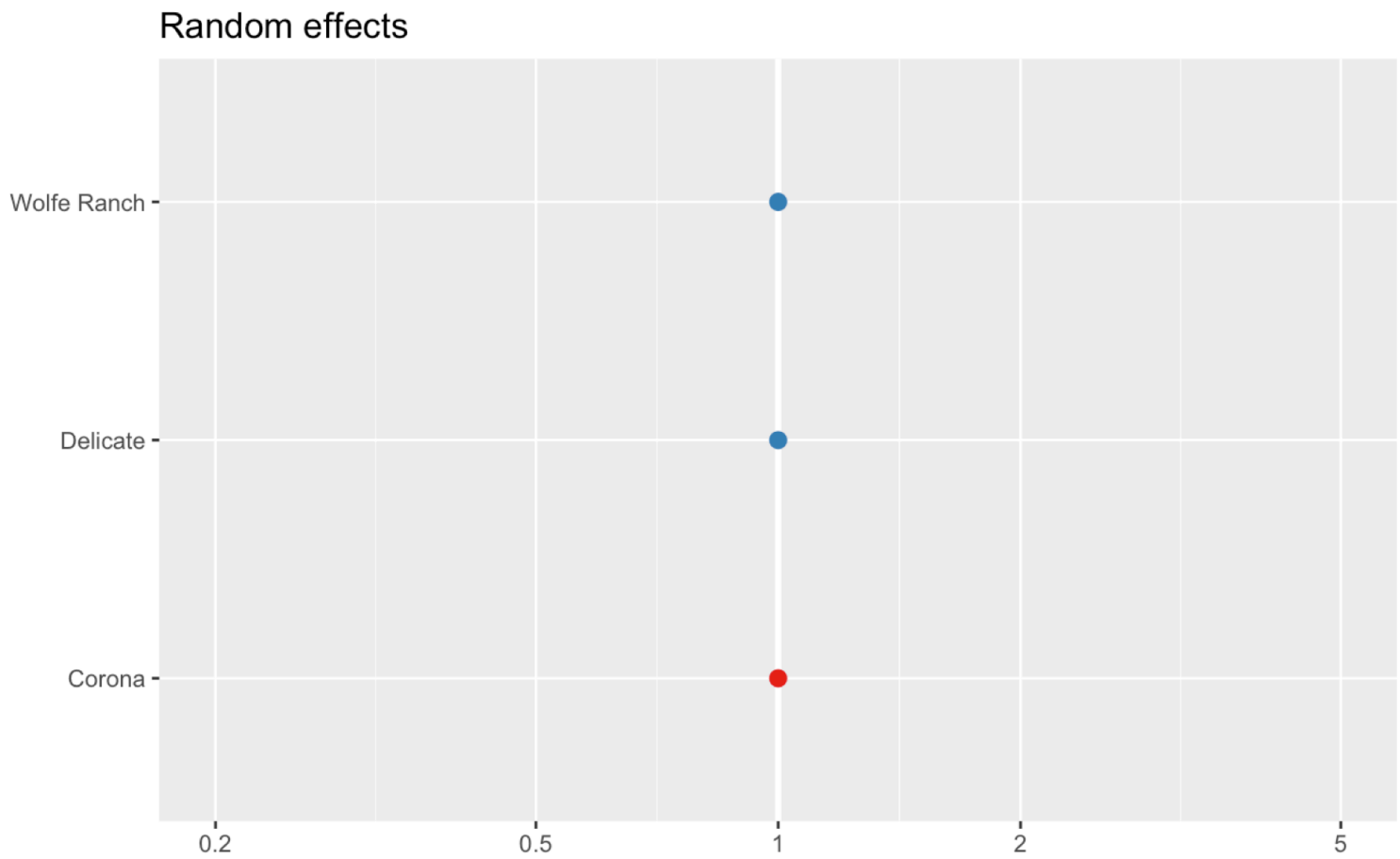

